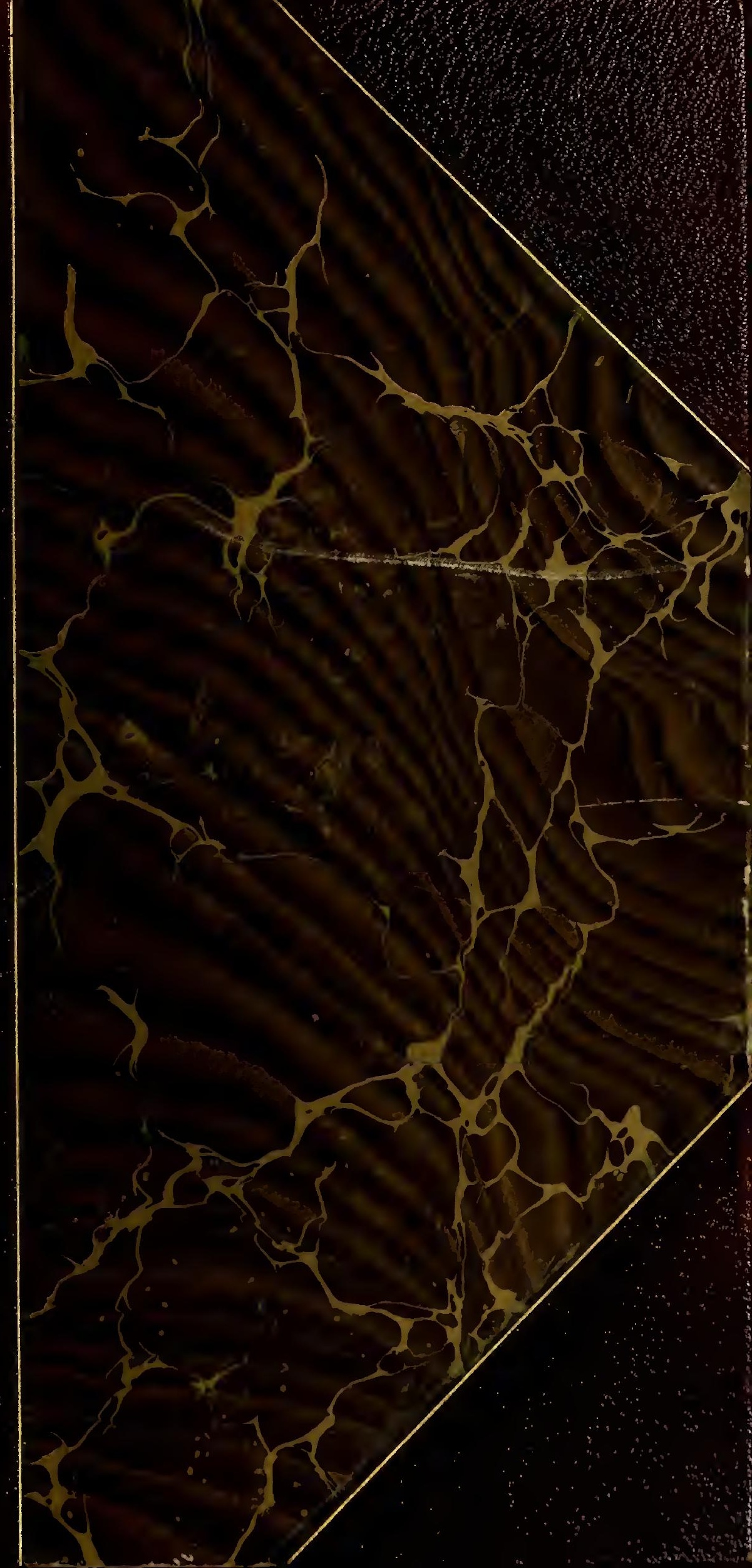


HARVARD UNIVERSITY.

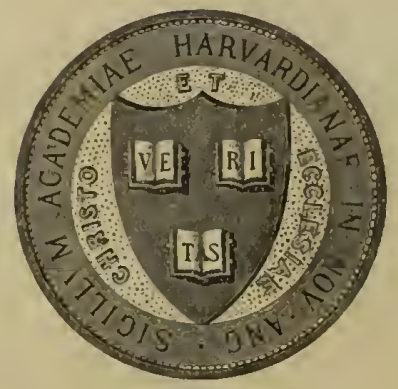

LIBRARY OF TIE

MUSEUM OF COMPARATIVE ZOÖLOGY 1,92 GIFT OF

Samuel Henshow.

Colter 29, 1921. 
ОСТ $29 \quad 1921$ 
7 rels

oh $/ \mathrm{s} \mid$ - 




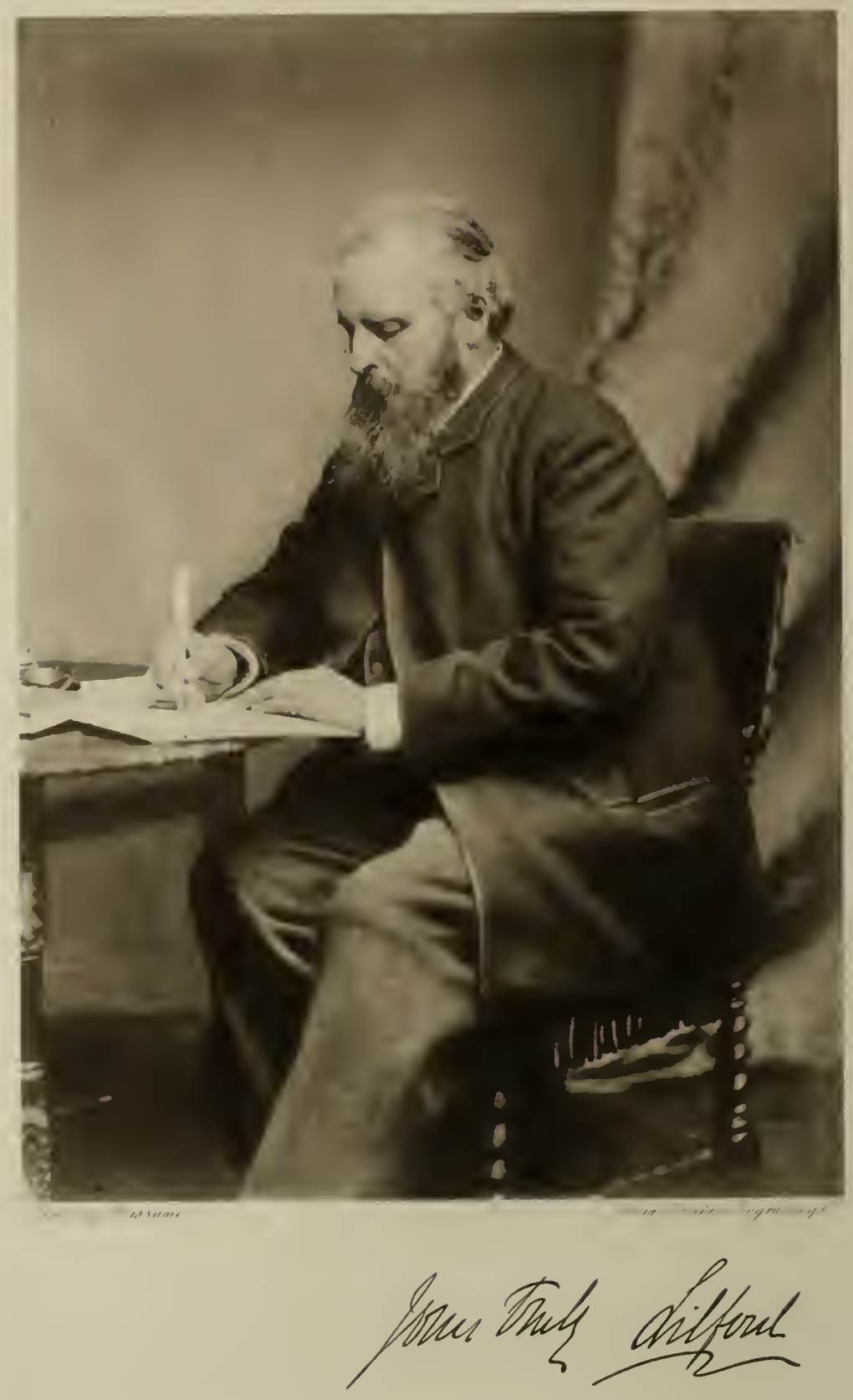






\section{COLOURED FIGURES}

OF THE

\section{BIRDS OF THE BRI'TISH ISLANDS.}

ISSUED BY

LORD LILFORD, F.Z.S., ETC.,

PRRSIDENT OF THE BRITISH ORNITHOLOGISTS' UNION.

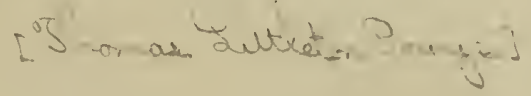

VOLUME I.

LONDON :

R. H. PORTER, 7 PRINCES STREET, CAYENDISH SQUARE, W.

$1885-1897$. 
lind $7 / 1982 \mathrm{~g} . \mathrm{J}$. 
TO MY FRIEND

\section{ALFRED NEWTON,}

PROFESSOR OF ZOOLOGY AND COMPARATIVE ANATOMY IN TIE UNIVERSITY OF CAMBRIDGE,

I DEDICATE THIS WORK

WITH

AFFECTION AND RESPECT.

\section{LILFORD.}

March, 1896. 



\section{CONTENTS OF VOLUME I.}

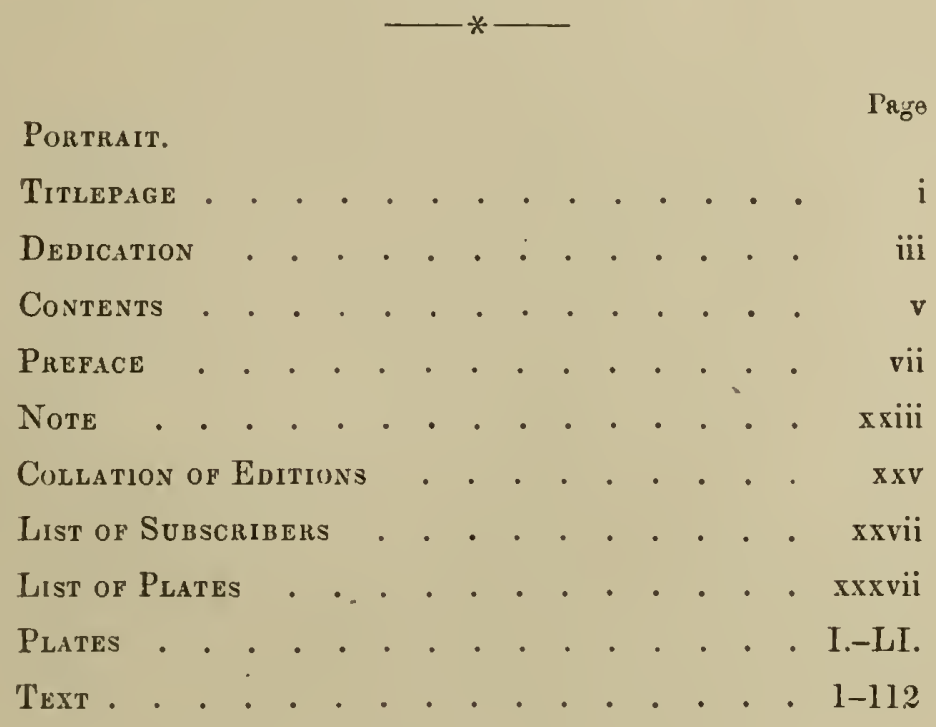





\section{PREFACE.}

Being honoured by a request, from a quarter which made compliance a duty as irresistible as it was gratifying, that I should write a Preface to this work, I feel I cannot do better than give some account of its originator, who was for ncarly forty-five years-though with occasional breaks-one of my nost constant, and, I may add, most valued correspondents. Born in Stanhope Street, Mayfair, on the 18th of March, 1833, Tromas Litrleton Powys was the eldest son of 'Thomas Atherton Powys, third Lord Lilford, and Mary Elizabeth, only surviving daughter of Henry Richard Fox, third Lord Holland, and Elizabeth Vassall his wifo-a couple sufficiently well known to all readers of social or political history. On his father's side I need not trace his ancient ancestry further back than to Sir Thomas Powys, who in 1686 was Solicitor-General to James II., and in 1713 under Anne a Judge of the Queen's Bench, an office from which he was removed on the accession of the House of Hanover. He then retired to Lilford in Northamptonshire, an estate which, with its fine Hall (one of the best examplcs of Jacobean 
arclitecture that this country can shew), he had bought a few years before, and there ended his days in 1719 .

At a very early age Mr. Powrs manifested that affection for animals which intensified as time went on, and this shewed itself in the way usual among schoolboys, so that at Harrow, whither he was sent, he was not only a keen collector of zoological specimens, but even kept a small menagerie, which (as he himself told me) brought him more than once into trouble with his masters. From Harrow was written his earliest published note (Zoologist, page 2775), and there he stayed until 1850, in which year he was placed with a tutor at Geneva, with the result that he was the first Englishman to give any information (op. cit. page 2968) as to the breeding of the Rose-coloured Starling, though, from what we now know, the instances of which he was told by the Curator of the Museum at that place were certainly abnormal. Early in May 1851 le left Switzerland, and was entered at Christchurch, where he speedily established a larger menagerie, which a few months later comprised examples of nearly a dozen species of Birds of Prey, beside other animals. He continued contributing notes to 'The Zoologist,' and it was one of these that, in 1852, led to our correspondence, which, though slackening at times, was kept up until his death. As became his youth, he was sanguine, and, as became his nature, unsuspicious; it must therefore not be imputed as a fault to him, that then, and even later, lie accepted without hesitation much that 
was told him as true but afterwards proved to be fictitious. Indeed he, for many years, stoutly defended, against my declared incredulity, the statement of a friend who professed, with some circumstance, to have taken a Shore-Lark on its nest near Exmouth *, and it was not until toward the close of his life that he mournfully owned that he had been deceived by his informant. I record this incident not only because it was the beginning of our intercourse, but because it was an early instance of his characteristic fidelity to his friends. During 1853 I had nearly a score of letters from him, but though each shews his devotion to the field-study of Bird and Beast, I am bound to say that not one contains matter of general interest, for he usually wrote in haste, and did not stay to describe his doings in Scilly, Wales, or Ireland, all of which he visited for the purpose of making personal acquaintance with their animals. In the same year too he first met the late Edward Clough Newcome, the best falconer of his day, whose example was not lost upon Mr. Powrs, for he subsequently became a staunch member of the Old Hawking Club, beside keeping a falconer and many Hawks of his own. In 1854 he again passed some time in Ireland, but soon after, on the outbreak of war with Russia, the Militia was embodied, and he joined that of his county. However a barrack-life, whether in Dublin or at

* So certain was he about it, that in 1853 my late brother Edward went specially to the spot, where, it is needlcss to say, he did not find any Shore-Larks; but there wero Rock-Pipits. 
Devomport, in which places he was chiefly quartered, was hateful to him; and as leave of absence could be often obtained, he availed himself of every opportunity thereby afforded of visiting the wilder parts, and especially the coasts, of England, Wales, and Ireland. To his regret circumstances hindered him from accompanying his regiment to the Mediterranean, whither it was sent in 1855 , and toward the end of that year he gave up his commission.

In February 1856 I first met Mr. Powrs, to the equal gratification, I think I may say, of each of us, as well as of our friend Mr. Newcome, then living at Hockwold Hall, where we were guests together; and in the summer of that year Mr. Powys was able to put into execution the idea he had long cherished of an extended yacht-voyage to Southern Europe. Embarking with a friend * on the 'Claymore,' they touched at various ports on the coast of Spain, making some stay in the Balearic Islands, and visited Corsica and Sardinia. He wrote to me in October of that year from Cagliari, giving a long list of the birds he had seen alive or dead during the cruise. They thence sailed for Sicily, but encountering a violent gale of wind, in which the yacht reccived some damage, they had to put into Malta for repairs. As the execution of these needed some time, Mr. Powrs betook himself to Tunis, where he passed two montlıs, enclianted with the zoological wealth of the country and cnjoying very fair sport. Thence he

\footnotetext{
* The Honourable Hercules Rowley.
} 
proceeded to the Ionian Islands, reaching Corfu on Christmas Day 1856, and there he stayed "off and on" until July 1859, making frequent excursions for sport or natural history to the opposite coast of Epirus or Etolia, going even so far to the northward as Montencgro. The results of this prolonged residence in those parts were communicated by him to 'The Ibis' for 1860 - the establishment of which journal he cordially approved, joining the British Ornithologists' Union so soon as he heard of its intended formation-and while they shew with what earnestness he entered into his pursuits, undeterred by bad weather, fatigue, or sickness, the same series of papers reveals in many a passage that delicate and admirable humour which so markedly distinguisleed him.

Leaving the Ionian Islands he proceeded to the Sardinian dominions, being very desirous of shooting an Ibex; but herein his hopes were mortified, for on reaching Savoy he found that but a short time before the chase of that animal had been forbidden to all but the King (Victor Emmanuel), and leave even to look at one was not to be obtained. He consequently had to content hinself with Chamois, whose acquaintance he had already made in Thessaly, and subsequently with the Moufflon in Sardinia. However he was not meanwhile without compensation; for, by the beginning of 1859, he had become cngaged to marry Emma Elizabeth, the very beautiful daughter of Mr. Robert William Brandling, of Low Gosforth in Nortlumberland, to 
whom he liad long been attached, and returning to England shortly after, their wedding was celcbrated in the following June.

The next twelve months were passed quietly, if not at home at least not in foreign travel; but in little more than a year his hereditary enemy, the goutwhich had shewn itself even while he was a schoolboy at Harrow-laid hold upon him, and confining him to the house for a time incapacitated him from the enjoyment of field-sports. Meanwhile the aviary at Lilford continued to grow, and at the end of October, 1860, he was able to write to me :-

"I have taken to hawking, not yet with any striking result except allowing a fine Goshawk to escape. The Zoologist will probably present its readers with'On — the keeper of —— Esq. of Northamptonshire, slot a fine specimen of that rare bird the Golden Eagle. Its tail is long, its eyes are yellow. Mr. - the well-known taxidernist of pronounces it to be an adult male, etc. etc. etc.'-and this will be my femalc Goshawk."

Again at intervals he suffered from the same disease, which was destined to mar the remainder of his life: and a very severe attack supervening in the autumn of 1861 , suon after the death of his father, when he succeeded to the family honours and estates, temporarily disabled him from walking. Yet he was able to attend the General Meeting of the British Ornithologists' Union in London on the 11 th of December, as well as that of 1862 , which was held at Cambridge on the 7 th 
of October, during the Annual Meeting of the British Association for the Advancement of Science. 'The few survivors of those who were present can hardly forget the spirit with which he entered into the proceedings of the 'Thorough' dinner at the Red Lion Hotel in this town, under the presidency of Professor Huxley, with Professor Kingsley as Vice-Chairman. It would be out of place here to enter into details; but the dinner was to celebrate the victory won, after a hard-fought struggle, by the adherents of the principle of Evolution over their opponents, who had manfully disputed what now proved to be an untenable position.

At the meeting of the British Ornithologists' Union held in London on the 20th of May, 1864, Lord Lilford not only proposed that a New Series of 'The Ibis' should be begun in the following year, but undertook, on its being continued in its existing form, to defray the cost of a plate in each number-a promise that was more than literally fulfilled for the rest of his life; and to that journal for 1565 he contributed an excellent sketch of the ornithology of Spain, as observed by himself in two visits, the first (as before mentioned) in 1856 , and the second in the early spring in 1864 , which confirmed the favourable impression he had already formed as to the country and all that belonged to it. 'To Englishmen Spanish Ornithology was a field almost untrodden, and its fertility came to many as a surprise; yet on the former of these visits only a few 
ports had been touched, and his notes on the latter refer to little more than Andalusia and the neighbourhood of Valencia, though these districts are among the richest in the peninsula. Spain, as he subsequently wrote, had been the subject of his youthful dreams by day and night, and, after his previous agreeable experience, it was only natural that he should renew his attempt to become better acquainted with it-indeed it may be truly said that, to the end of his days, his interest in cosas de España, and especially its ornithology, never slackened. Accordingly in the spring of 1865 he returned thither, accompanied by Lady Lilford, and this time obtained leave to carry on his observations in the grounds of the Casa del Campo and of El Pardo-royal domains near Madrid,-as well as subsequently at Aranjuez and Sotomayor. Thence he proceeded to San Ildefonso and Segovia; but his hereditary enemy pursued him, and for a great part of the time he was unable to walk. The admirable narrative of his doings may be read, and always with delight, in 'The Ibis' for 1865 and 1866, and not a little contributed to his election-by acclamation it may be said-to the Presidency of the British Oruithologists' Union, when, on the 27th of March, 1867, it was resigned by Colonel Drummond-Hay.

It has seemed advisable to dwell on these earlier days of Lord LiLForD's career, since they must be little known to the ornithologists of the present time, and in his efforts and example he was second to none in obtaining for 'The Ibis' that high reputation which it 
so speedily acquired and has so long sustained. His enthusiasm never flagged, as his frequent communications in later years testify; but his subsequent cruises in the Mediterranean Sea (including three more visits to his beloved Spain between 1566 and 1Si5), which made him familiar with almost all the parts of its coast and islands that were interesting to the ornithologist, and extended to the shores if not the interior of Crprus, produced fewer novelties-the discovery in April 1579 of the most westerly breeding-place of Audouin's Gull being perhaps the chief of them.

These cruises did not, however, occupy the whole of lis time. Each recurring shooting-season found him in this country, exercising hospitality either in his Northamptonshire home or in Scotland, where he for several years hired one of the finest deer-forests; and, though often incapacitated by gout from taking to the hills, he would listen with pleasure to his guests as they recounted the varied events of the day's work with gun, rifle, or rod; while, whenever his own condition permitted, he proved himself as "game" a stalker, and as successful, as if he had been in possession of the full use of his limbs.

With all this devotion to sport he never allowed it to interfere with the duties to which he was called by his position, and of those duties he had an exalted idea. Though he had little taste for politics, he did not neglect duly to appear in his place in Parliament, and it was with satisfaction that he used to recall his successful addition of "Owl" to the Schedule of Birds to be 
protected by law in the Bill of 1880 , which subsequently passed into an Act, especially as he was put to no little personal inconvenience by attending the House of Lords at that particular time. With him the protection then first accorded to Owls, a fact overlooked by many recent writers or speakers on the subject, was no question of sentiment only. He knew, and no one better, how beneficial Owls are to the farmer and the gamepreserver-though the latter will hardly ever admit it.

The course of life hitherto led had been only interrupted occasionally by the malady to which he was subject, but it was rudely broken in the autumn of 1882 , by the death, after a short illness, of his eldest son, who had but recently attained his majority. This loss was greatly taken to heart, and was followed within little more than a year by a still heavier blow in the death of Lady Lilford-a loss more felt now that he himself was becoming a permanent invalid, some three or four acute attacks of his insidious disease having begun to cripple his hands and feet. In all this time and under all these afflictions neither his kindliness nor his cheerfulness forsook him. Both his letters and his conversation, tinged as they were with grief, evinced his natural wit and humour, brought perhaps into greater prominence than before by their contrast with words, occasionally let drop, that slewed low deeply his feelings had been stirred. Yet there was no forced pleasantry, for a man more free from affectation can scarcely have lived. The real consolation was found when some time after 
he married a dear and intimate friend of his deceased wife, Clementina, daughter of the late Mr. BaillieHamilton, whose intense devotion to her husband for the rest of his life can be only reverently recorded and not recounted.

In his own county was organized a Natural History Society, of which he was not only the President, but the mainstay, and to its 'Journal' he began, in 1880, to contribute a series of papers on the Birds of Northamptonshire, which were finally republished, with many additions, in two volumes under that title only a short time before his death. The gencrosity with which he supported almost every scheme that made for the progress of Zoology might have been called lavish had it not been tempered by discretion. Enough to say that on a good case being made out his pecuniary help was always forthcoming, and never stinted in amount. But often he did not wait for a case to be brought to his notice, and of himself would find opportunity and the man for it. A notable instance of this subsequently happened in regard to the zoology of Cyprus, which he commissioned Dr. Henry Guillemard to investigate, with results well known to readers of 'I'he Ibis.'

As before said, Lord Lilford's interest in all that concerned Spain never relaxed, and next to his own country his sympathies lay with that whose language he loved to study and speak. He hailed with pleasure the appearance in 1887 of the 'Aves de España' by Don José Arévalo, published in the Memoirs of the Royal VOL. I. 
Academy of Sciences of Madrid. Indeed he himself had at one time planned a work on the subject, and went so far as to have some plates executed for its illustration, which (on finding that he was never likely to carry out the idea) he gave to Colonel Irby, his old friend and companion in many an expedition, that they might embellish the second and revised edition of his useful 'Ornithology of the Straits of Gibraltar,' in which they were published in 1895 .

Long before this time, however, the scheme of the present work occurred to Lord Lilford. He had, hanging on his walls or stored in portfolios, a number of pictures of Birds by various artists, the contemplation of which always afforded him pleasure, and even relief when racked by pain. That pleasure he thought should not be confined to himself, and he was willing to put it into the power of other lovers of Birds to possess, at a comparatively moderate cost to themselves, whatever might be the expense to him, portraits of their favourites. The help of Mr. Wolf, whose works he justly held in the highest admiration, was unhappily no longer available, but with the services of Mr. Keulemans he thought that most people might be content. Accordingly arrangements were made with that artist for a series of drawings, and the first part of the work appeared towards the end of the year 1885-the plates being chromolithographed in Berlin. As the distance of that city caused a good deal of inconvenience, trial was made 
in several quarters to have them executed nearer home; but the result was not on the whole satisfactory, so that eventually recourse was again had for the most part to the Prussian capital, and certainly there is little fault to be found with the work latterly turned out from Herr Greve's establishment. Gradually the artistic assistance of Mr. Lodge, Mr. Neale, and Mr. Thorburn was invoked, and the later portion of the work has been illustrated wholly by a faithful reproduction of beautifully finished pictures-hardly one of which is not a joy to gaze on-by the accomplished gentleman last named. As the plates were intended to be the main feature of the work, the accompanying letterpress was at first of the briefest. By degrees, however, the natural impulse to dwell upon the interesting subjects depicted grew irresistible, and in some instances particulars of the several species figured were given at considerable length, and generally from the writer's own experience.

Ever since Lilford came into his possession, its orner's love of live animals kept on developing itself. The stable-yard and adjoining courts and outhouses of the old Hall were, one after another, brought into requisition, and made to accommodate a vast assemblage of beasts, birds, and reptiles, especial care being taken to adapt their several quarters to the comfort of the inhabitants. This consideration, too often neglected by those who have the control of vivaria, was constantly borne in mind by Richard Cosgrave, a faithful and assiduous attendant, whose morning report on the condition 
of his charges was daily expected by his master. Place was found, though at some distance from the house, for the erection of large and commodious aviaries, the tenants of which frequently testified to the suitability of their lodging by matrimonial alliances, and possibly there have been few establishments of the kind in which the captives have to such an extent been tempted to solace their imprisonment by indulging in the tender passion. After a time, too, a large piece of water in the park, with a wide border of shrubbery and turf, was securely fenced in, and in this enclosure was maintained, safe from the depredations of the well-known foxes of Northamptonshire, one of the finest collections of living Water-fowl-and especially of the Crane-family-that has ever been formed. But this was not all : round the house might be seen no small number of Birds enjoying almost absolute freedom, from the miglity Lämmergeyer to the Little $\mathrm{O}$ wl, dear to Pallas Athena, of which last several pairs nested in the hollow trees of the gardens and park. Indoors were a few especial favourites, of constitution too delicate to be exposed to the weather, and among them the Torillo, whose deep note in the silent hours of the night would surprise the unwary visitor, who had not thought the somewhat meek-looking "Button-Quail " capable of uttering such a terrible sound. Of late years the aviaries at Lilford, with its beautiful gardens, became an object of great public attraction, and access to them being readily given, on at least one day in the week, the population of 
the neighbouring towns and villages availed itself largely of this privilege-a privilege that year by year, through the increase of his bodily infirmities, the owner of all became less and less capable of enjoying. Yet whenever, and as often as, he could, he would be drawn in his wheeled chair to one after the other of the cages or pens, taking the closest interest in the individual history of each denizen, and shewing that personal knowledge of each that only belongs to those who have a natural love of living animals.

In the earlier years of his presiding over the British Ornithologists' Union, and when that body was comparatively sinall in number, not only was Lord LiLforD the friend of almost each member, but all were welcome at "The Den," as he termed some rooms he occupied in London, and especially on the evenings of the Scientific Meetings of the Zoological Society, when most of the ornithologists present would adjourn to No. 6 Tenterden Street, and there talk over their achievements and their prospects, and generally cultivate one another's friendship. That these gatherings greatly promoted the harmonions feeling which then prevailed annong British ornithologists is unquestionable, and their discontinuance, owing chiefly to his inability to be present, was much to be regretted. For sevcral years lic was compelled to pass the winter at Bournemouth, and after that he was never able to leave Lilford; but whorever he was he exhibited the same patience under his affliction and the same kindly consideration for his friends 
and all about him. In $159 \pm$ the marriage of his elder surviving son, John, the present Lord Lilford, gave him great pleasure, which was increased in due time by the birth of a grandson. During the spring of 1896 he had several repented attacks of his old malady, though none of uncommon severity; but on the 17th of June, in that year, an unexpected collapse closed the useful and blameless life of which this is a very imperfect sketch.

'Though so long suffering from a painful hereditary disease, he had the compensation of a genial hereditary disposition. On the one side he was endowed with social cliarms like those which won for his mother's great-uncle, Charles James Fox, the love of so many friends; while on the other side to him clearly descended the characteristic, expressed by the pen of Matthew Prior, and still to be read on the monument of his paternal ancestor (the first Sir 'T'homas Powys of Lilford) in the transept of Thorpe Achurch, of being "possessed by a natural happiness."

Cambridge, A. N. Christmas 1897. 


\section{N O T E.}

A FEW words seem necessary to explain my small share in bringing this work to a conclusion.

When, on the lamented death of its originator, this task was entrusted to me, I found that nearly the whole of the Plates of the birds remaining to be figured were in a more or less advanced state of preparation, some finished, some with the lithographers, and on some the artist was engaged. Moreorer a list of the figures of species as yet unissued was in the Publisher's hands, but no portion of the letterpress had been written. To this list, which seems to have been mainly derived from Col. Irby's 'Key List of British Birds,' I have adhered very closely, concluding that the birds not named in it were not intended to be figured. The only additions I have ventured to make are the two Willow-Warblers Phylloscopus viridanus and $P$. proregulus, which appeared in England in the autumn of 1896, and Procellaria cryptoleucura, and no bird recorded since the close of 1896 has been added.

Regarding the letterpress, it was obrious that to attempt to compile any notes of the species on the 
lines adopted by Lord Lilford himself in the later parts of his work could not be satisfactory, and it also seemed unadvisable to revert to the short notes of the earlier parts. I therefore took a somewhat middle course and confined my notes in each case to a brief statement of the claims of each species to be considered a British Bird and to a short summary of its external gcographical distribution.

Regarding the final systematic arrangement of the work, I may add that in June 1895 Lord Lilford drew up a rough list of the groups of British Birds placed in the order in which he considered they ought to stand. 'This list was submitted to me and a few suggested alterations werc accepted. The order of this list has now been adopted, very slightly adjusted to admit spccics that had been ovcrlooked. It is, in many respccts, the order of the Fourth Edition of 'Yarrell's British Birds.'

In an Appendix to Volume VII. I have given a List of Birds said to have occurred in the British Islands, but of which no further mention will be found in this work. No attcmpt is made to investigate their respective claims to be included in the British list.

$$
\text { O. S. }
$$

Hawksfold,

Fernhurst,

Christmas 1897. 


\section{COLLATION OF EDITIONS.}

Tнis Work was issued in two Editions: the First commenced October 1885, and the Second April 1891, both Editions ending simultaneously; the Plates in Volume I. appeared as follows :-

1st Edition.

PART

X. Mar. $18 \$ 9$.

IXV. Oct. 1893.

XXXI. June 1895.

XXV. Oct. 1893.

XYI. Sept. 1890 .

IIII. Mar. 1890. XIII. June 1892.

XXYI. June 1895. XXYI. June 1895.

IVII. Feb. 1891. XXII. June 1893.

XIV. May 1890. TII. Nor. 1892.

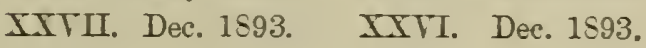

10. Rotgh-LEgGed BCZZARD.

11. Hoxer-Bezzard .....

12.

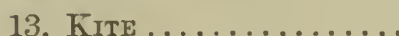

14. Brack Krre.........

15. Grr Falcor .......

16. ICELAN Faucor ......

17 .

18. Greenlind Falcoy ..

19. Peregrise Falcos .... 20.
XI. Sept.18s9. XI. Feb. 1892. XIX. July 1S91. XII. May 1892. XIX. Feb. 1895. TXX. Feb. 1895. IXIX. Nov.189t. XXIX. Nov. 1894. XVII. Feb. 1891. XXII. June 1893. XII. Jan. 1890. XXIIl. dug. 1894. 


\begin{tabular}{|c|c|c|c|c|}
\hline & 1st & on. & 2nd & $n$. \\
\hline & PART & & PART & \\
\hline 1. Новвг ... & III. & Aug. 1886. & III. & Apr. 1891 \\
\hline$\ldots \ldots$ & II. & May 1886. & II. & ", \\
\hline 23. RED-Footed FaLCoN $\ldots$ & XXVII. & Dec. 1893. & XXVI. & Dec. 1893. \\
\hline 24. Merlix............ & XVI. & Sept. & XVII. & Nov. 1892. \\
\hline$\ldots \ldots \ldots \ldots$ & XIX. & July & XII. & Nay 1892. \\
\hline 26. Krstrel $\ldots \ldots \ldots \ldots$ & XVI. & Sept. 1890. & XVII. & Nov. 1892. \\
\hline 7. Lesser Kestrei . . . . . & XXII. & Dec. & XVIII. & Dec. 1892. \\
\hline 8. Gos-Hawk $\ldots \ldots \ldots$ & XIX. & July 1891. & XII. & May 1892. \\
\hline,$\quad \ldots \ldots$ & $"$ & & , & \\
\hline 30. Sparrow-Hawk ... & $\mathrm{V}$. & June 1887. & V. & June 1891. \\
\hline 31. & IV. & Jan. 1887. & IV. & 1891. \\
\hline$" \quad \ldots$ & $"$ & $"$ & $"$ & ", \\
\hline,$\quad \ldots .$. & , & 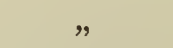 & , & . \\
\hline 34. Marsh-Harrier ...... & $\mathrm{XIV}$ & May 1890. & $\mathrm{X} \nabla \mathrm{I}$. & Nor. 1892. \\
\hline 35. $\quad, \quad " \quad \ldots \ldots$ & $"$ & & " & \\
\hline 36. Hen-Harrier . . . . . . . & XXI. & Aug & $X \nabla$. & 892. \\
\hline 37. Montagu's Harrier .. & XXVII. & $\mathrm{De}$ & XXVI. & 393. \\
\hline , & XXIX. & Nov. 1894. & XXIX. & Nov. 1894. \\
\hline 39. GRIFFor VULtURE $\ldots$ & XXIII. & Mar. 1893. & $\mathrm{XX}$ & Iar. 1893. \\
\hline $\begin{array}{l}\text { 40. Neophron or Egrptian } \\
\text { Vulture. }\end{array}$ & $"$ & $"$ & " & " \\
\hline $\begin{array}{l}\text { 41. TAWNY, Brows, or } \\
\text { Wood-OWL. }\end{array}$ & XI. & Sept. 1889. & $\mathrm{XI}$. & eb. 1892 . \\
\hline 42. & $\mathrm{XXV}$. & Oct. 1 & XXIV. & Oct. 1893. \\
\hline 43. Tengaram.s's OWL . & $\mathrm{XXX}$. & Feb. 1 & $\mathbf{X X X}$ & Feb. 1895. \\
\hline 44. LoNG-EAREd OWL $\ldots$ & XXIII. & Mar. 1893. & $\mathrm{XX}$. & Mar. 1893. \\
\hline 45. Short-eared OwL .... & $X I$. & Sept. 1889. & XI. & Feb. 1892. \\
\hline 46. EAGLE-Owh ...... & & & $"$ & \\
\hline 47. Scops OWL $\ldots$ & III. & Aug. 1886. & III. & Apr. 1891. \\
\hline 48. Littlle Owl......... & $"$ & & $"$ & . \\
\hline 49. HawK-OWL .... & $\mathrm{XII}$ & Mar. 1890. & XIII. & June 1892. \\
\hline 50. SNowy OwL ... & XVIII. & Apr. 1891. & XIX. & Feb. 1893. \\
\hline 51. Barn-Owl $\ldots \ldots \ldots$ & XIV. & May 1890. & XVI. & Nov. 1892 \\
\hline
\end{tabular}




\section{LIST OF SUBSCRIBERS.}

\section{H.M. THE KING OF PORTUGAL.}

Prof. T. Clifford Allbut, LL.D., | Walter Bates, Esq. F.R.S.

W. C. Allen, Esq.

P. Bearcroft, Esq.

W. J. Beaumont, Esq.

The Rev. H. F. Allison, M.A.

Victor Aures, Esq.

The Rev. W. Becher, M.A.

Jону T. Bell, Esq.

Sir Percy Anderson, K.C.M.G. (the late).

The Earl of Antrin.

Fred. C. Aplin, Esq.

R. D. Archer-Hind, Esq.

The Duke of Argyll.

Mrs. Mark Ashton.

The Rev. Hubert D.Astrey,M.A.

E. T. Aткrn, Esq.

A. E. Bellairs, Esq.

W. Bethell, Esq.

Messrs. Bickens \& Son.

Colonel J. Biddulph.

E. Bidwell, Esq.

R. Binghai, Esq.

The Rev. M. C. H. Bird, M.A.

Messrs. W. Blackwood \& Sons.

E. WV. BldGg, Esq.

Capt. Blair.

J. Atrinson, Esq.

T. Audas, Esq.

J. Backhouse, Esq.

W. Borrer, Esq., M.A.

F. Bostock, Esq.

J. G. A. BAIRd, Esq.

R. J. Balston, Esq.

The Lord Boston.

Captain Boultbee.

Colonel Hanbury Barclay.

Hugit G. Barclay, Esq.

Cecil Boyle, Esq. (2 copies.)

The Hon. C. Brand.

The Lord Braybrooke.

T. J. Barratt, Esq.

R. M. Barrington, Esq.

B. F. Barton, Esq.

The Venerablc Arcudescos Bree, D.D. 
Colonel The Hon. F. C. BridgeMAN.

E. K. Bridger, Esq.

British Museum (Bloomsbury).

British Museum (Natural Histo RY).

W. F. Brockholes, Esq.

Н. Вrоке, Esq.

Rev. Stoptord A. Brouke, M.A.

J. Brooking-Rowe, Esq.

G. Brooksbank, Esq.

Miss Brooksbank.

E. A. Brown, Esq.

J. A. Harvie Brown, Esq.

R. Сuthвевт Brown, Esq.

Mr. W. Brown.

R. T. Hamilton Bruce, Esq.

C. Buckley, Esq.

J. F. Buckley, Esq.

'T. E. Buckley, Esq., B.A.

Messrs. J. \& E. Bumpus, Ltd.

Mr. T. B. Buypus.

W. Arnold Burgess, Esq.

Capt. Burs.

C. M. Pelham Burn, Esq.

Robert Burra, Esq.

'T. H. Burroughes, Esq. (2 copies.)

Mr. W. Burton.

Mrs. E. Burton.

Colonel E. A. Butler.

Geoffrey F. Buxton, Esq.

S. Gurney Buxton, Esq.

Mr. J. Calyert (the late).

Cambridge University Library.
A. L. Caminele, Esq.

Tine Carlton Club.

F. L. Carslake, Esq.

The Lord Castletown.

A. Cator, Esq.

J. CAvaFY, Esq., MI.D.

Mr. C. D. Cazenore.

Abel Chapman, Esq.

J. P. Charles, Esq.

Robert W. Chase, Esq.

A. J. Cholmley, Esq.

G. Herbert Chubb, Esq.

G. D. A. Clark, Esq.

Stephenson R. Clarke, Esq.

W. Eagle Clarke, Esq.

Herbert Sandford Claye, Esq.

Geo. H. Clemons, Esq.

Јонм D. Совbold, Esq.

W. Cochrane, Esq.

Major The Hon. W. Core.

A lffed Horsman Coles, Esq.

T. A. Colfox, Esq.

William B. Collier, Esq.

J. L. Collison-Morley, Esq.

J. J. Colman, Esq., M.P.

Rev. J. E. Campbell Colquhoun, M.A.

R. H. Сомве, Esq.

Mr. J. G. Comain.

J. A. Cooper, Esq. (the late).

Mrs. Cooper.

J. Cordeaux, Esq.

Mr. J. E. Cornisir.

Messrs. Cornish, Bros.

T. A. Сотton, Esq. 
Capt. Alexander Cowle, R.E.

J. Cowper, Esq.

H. F. Cox, Esq.

IV. Parry Crake, Esq.

Albert J. Crosfield, Esq.

The Rev. Cedric E. Crowley, M.A.

Philip Crowley, Esq.

Sidney G. Cummings, Esq.

Lady Cunliffe.

Robert Ellis Cunliffe, Esq.

The Hon. A. N. Curzon.

The Rev. Dr. Dallinger, F.R.S.

The Earl of Darnley.

H. S. Davenport, Esq.

P. B. Daries-Cooke, Esq.

J. S. Davy, Esq.

Mrs. Dennistoun.

The Earl of Derby.

H. G. Devas, Esq.

Viscuunt De Vesci.

The Duke of Devorshire.

Major Geo. Wixgfield Digby.

J. K. D. Wingfield Digby, Esq.

Colonel George -Dixon.

Douglas Dobie, Esq.

IV. H. Doeg, Esq.

E. D. Doncaster, Esq.

The Lord Doryer.

Capt. G. S. Douglas.

Capt. R. H. J. Douglas.

Messrs. Douglas \& Foulis.

The Dowager Viscountess Downe.

H. M. Draper, Esq.
H. E. Dresser, Esq.

The Hon. Mrs. Drewit

Dublin, Trinity College

LIBRARY.

J. H. Duncan, Esq.

Messrs. Dulau \& Co.

Edroxd A. Duxs, Esq.

Alexander Durr, Esq.

Rev. W. F. Eator, M.A.

Edixburgh Adrocates' Library.

G. M. Edyonds, Esq.

S. E. ElANd, Esq.

Ernest A. Elliott, Esq.

The Hon. Chas. Ellis.

H. M. Eluis, Esq.

H. E. G. Eva.rs, Esq.

The Rev. J. A. Ewing, M.A.

The Marquis of Exeter.

Ernest Farquhar, Esq.

John Farrah, Esq.

Mrs. FeildeN.

General the Hon. Sir Percy R.

B. Feildivg, K.C.B.

Major H. J. Fergusson.

Alax G. Finch, Esq.

L. P. Fisher, Esq.

Rev. Wilfred Fisher, M.A.

W. H. B. Fletcher, Esq.

Wickнail Flower, Esq.

C. G. Sarile Foljambe, Esq., M.P.

JoIN W. Ford, Esq.

T. H. Forgax, Esq.

Riley Fortune, Esq.

TV. Foster, Esq. 
C. R. Gawen, Esq.

Thomas George, Esq.

Johy Gerrard, Esq.

Miss Dorothea H. Gibis.

Sir Jaues H. Gibson-Craig, Bart. Sir Walter Gilbey, Bart.

The Rev. H. H. Gillett, M.A.

Sir John Gilmour, Bart.

F. DuCane Godman, Esq., F.R.S.

H. St. Barbe Goldsmith, Esq.

G. I. Goodheart, Esq.

Captain G. I. Gould.

Sir George Macpilerson Grant, Bart.

C. Macpherson Grant, Esq. (the late).

J. F. Green, Esq.

Sir Gilbert Greenall, Bart., M.P. (the late).

B. W. Gruith, Esq.

Dr. A. Günther, F.R.S.

Mrs. John Gurney.

Richakd H. J. Gurney, Esq.

G. H. Caton Haigh, Esq.

J. P. Wilton Haines, Esq.

Messrs. Mamilton, Adans, and $\mathrm{Co}$.

A. Hammond, Esq. (the late).

H. C. Hanipson, Esq.

Mrs. George Hanbury.

Lionel Hanbury, Esq.

E. W. Harcourt, Esq., M.P. (the late).

Basil W. Hardcastle, Esq.

J. HARDie, Esq.
Reginald G. Hargreaves, Esq.

Colonel Harrison.

Lawrence Harrison, Esq.

Messrs. Harrison \& Sons.

J OHN HARROP, Esq.

J. Hastings, Esq.

Messrs. Hatchards.

Rev. H. S. Hawkins, M.A.

(the late).

J. Clarke Hawkshatw, Esq.

Charles T. Hebbert, Esq.

John G. Heckscher, Esq.

Dr. Henderson.

George Henderson, Esq.

The Lord Henniker.

Dr. H. Bendelack Hewetson.

Rev. J. R. Hewitson, M.A.

C. R. C. Hibbert, Esq.

R. F. Hibbert, Esq.

Rev. T. S. IIthens, M.A.

The Hon. Lady Higginson.

Berkeley Hill, Esq. (the late).

H. A. Hills, Esq.

W. T. Hindiarsh, Esq.

Lady IIolland (the late).

F. H. Holmes, Esq.

The EarL of Hone.

G. P. Hope, Esq.

H. P. Нorby, Ésq.

W. L. Horley, Esq.

T. C. Honsfall, Esq.

Robert J. Howard, Esq.

The Dowager Lady Howard de WALDEN.

James C. Howden, Esq., M.D. 
Mr. E. Howell.

Reginald Hudson, Esq.

Lieut.-Col. J. M. Hunt.

J. H. Hutchinsox, Esq.

Colonel L. H. Ікву.

Ireland, National Library of.

Jaues J. L. Inving, Esq.

Sir Cinardes E. Isinam, Bart.

R. D. JACKson, Esq.

H. Berkeley Jayes, Esq. (the late).

William D. James, Esq.

C. E. Jennings, Esq.

Harry Clarke Jervoise, Esq.

II. J. Johnson, Esq.

John Algernon Jodes, Esq.

Major H. Jones.

Messrs. Joves \& Evans.

R. F. Wynne Jones, Esq.

W. C. Jones, Esq.

Rev. H. W. Jukes, M.A.

V. A. Julius, Esq.

Junior Caklton Club.

Mr. F. Justen.

Prof. Ch. vai Kempen.

Lady Coleridge Kennard.

Mrs. Kennedy.

T. S. KeNedy, Esq.

Colonel E. G. KePPEL.

Join Kermack, Esq.

P. M. C. Kermode, Esq.

The Lord Kesteven.

T. M. Kitchen, Esq.

Mr's. W. H. SNeyd Kymersley.

R. S. Lamb, Esq.
C. J. Lambert, Esq.

Sir George Lampson, Bart.

Mrs. Norman Lampson.

H. Langton, Esq.

C. D. Lang worhy, Esq.

The Hon. Gerald Lascelles.

Capt. Lathan.

IV. B. LeE, Esq.

E. B. Lees, Esq.

M. Lees, Esq.

Mrs. Legh.

W. Hamilton Leigh, Esq.

W. Lethbridge, Esq.

Arthur Lewis, Esq.

Henry Letwis, Esq.

Clementina, Lady Lilford.

The Dowager Lady Lilford

(the late).

W. B. Lindley, Esq.

Frank Littleboy, Esq.

Captain Sт. J. D. T. Loftus.

The Marquis of Lothian, K.T.

The Earl of Lovelace.

MIajor A. P. Loyd.

Frederick Lubbock, Esq.

N. Luввоск, Esq.

Fren. W. Lucas, Esq.

James Lunisden, Esq.

The Lord Lyveden.

Davin MrBrayne, Esq.

A. McDonald, Esq.

Mrs. Agnes MeDouall.

Mrs. McIstosh.

- McQueen, Esq.

Capt.J.R. H. Macfarlane, R.N. 
George A. Macmillan, Esq. The Earl of Malmesbury. Manchester, The Portico LIBRARY.

T. J. ManN, Esq. (the late).

T. H. Manners, Esq.

Alderman J. K. MarshaLL, J.P.

Thos. Marshall, Esq.

Philip B. Mason, Esq.

Sir Herbert Maxwell, Bart., M.P.

E. G. Meade-Waldo, Esq.

Henry Mellish, Esq.

J. C. Melville, Esq.

Messrs. Menzies.

W. Merewether, Esq.

W. F. Middleton, Esq.

J. Guille Mrllars, Esq.

G. Miller, Esq.

Rev. William Mills, M.A.

E. Mrlner, Esq.

J. M. Mrtchell, Esq.

John Monckton, Esq. (2 copies.)

T. J. Monk, Esq.

H. C. Monro, Esq.

TheLord Montagu of Beaulieu.

Casimir de R. Moore, Esq.

Rev. E. M. Moore, M.A.

Captain G. H. Moore.

Miss M. T. B. Moore.

Mrs. E. T. Moore.

Alyred Morrison, Esq.

The Dowager Countess of Morton.

G. W. Murdoch, Esq.
Charles Murray, Esq. Mr. Henry C. Nattali.

E. Neale, Esq.

G. H. Nevile, Esq. Arthur Newall, Esq.

F. D'A. Newcome, Esq.

Professor Newton, F.R.S.

Walter B. Nichols, Esq.

F. Nicholson, Esq.

Rev. G. Nicholson, M.A.

A. Nimmo, Esq.

Messrs. James Nisbet \& Co.

Captain Sir ANdrew Noble, K.C.B., F.R.S.

Heatley Noble, Esq.

W. G. Norris, Esq.

The Earl of Northbrook.

F. M. Ogruvre, Esq.

Oldham, The Free Public LIBRARY.

H. M. Ormerod, Esq.

C. F. D'A. OrRed, Esq.

Oundle, Northants, Literary and Scientific Institution. Oxford, Bodleian Library.

E. Packe, Esq.

Mr. E. T. PAGE.

Captain R. Townley Parker

(the late).

T. PARKIN, Esq., M.A.

Cecil Parr, Esq.

Mrs. ParRIs.

Llewelyn S. E. Parry, Esq.

Dr. A. Gordon Paterson.

Mrs. Carlos Patteson. 
C. N. Peal, Esq.

Captain G. J. H. Pearson.

H. J. Pearson, Esq.

A. Pechell, Esq. (the late).

Dr. F. G. Penrose.

Mr. Young J. Pentland.

C. H. S. Perceval, Esq.

A. R. Percival, Esq.

Major Рнгввs.

E. Lort Phillips, Esq.

Captain Pigott, R.N.

T. Digby Pigott, Esq., C.B.

T. M. Pike, Esq., M.A.

Messrs. W. N. Pitcher \& Co.

John Platt, Esq., J.P.

Mr. R. Platt.

Mrs. Batten Pooll.

F. W. Leyborne Popham, Esq.

H. A. Powell, Esq., M.D.

P. E. Le Poer Power, Esq.

Colonel The Hon. C. J. Fox. Powrs (the late).

The Hon. L. W. H. FoxPowrs (the late).

H. L. Powrs-Keck, Esq.

Walter Prentis, Esq.

Frederic Pretyaian, Esq.

W. Mark Pybus, Esq.

Mr. B. Quaritch.

W. H. St. Quintre, Esq.

Pantia Ralli, Esq.

Major R. G. Wardlaw Ramsay.

W. F. Rawssley, Esq.

H. E. Rawson, Esq.

Robert H. Read, Esq.

VOL. I.
Colonel Exrs P. Fox Refue.

Captain S. G. REID.

Percy Rendall, Esq., M.D.

IV. Renshaw, Esq.

Mrs. Richardson.

D. Lloyd Roberts, Esq., M.D.

Mrs. Octavius Robinson.

W. D. Robinson-Douglas, Esq., M.A.

The Rev. Henry Rogers, M.A.

Major H. G. Rooper.

Charles S. Roundell, Esq.

The Hon. Maud Russell.

Mrs. Watts Russell (the late).

Mrs. Stopford Sackville.

Captain F. H. SALutin.

Osbert Salvin, Esq., F.R.S.

A. Sartoris, Esq.

Captain J. Sсотт.

J. Scott, Esq.

Exors. of the late A. Selby, Esq.

John D. Selby, Esq.

L. L. Shadwell, Esq.

R. Bowdler Sharpe, Esq., LL.D.

Sheffield Public Museum.

Captain G. E. Shelley.

The Lord Sherborne.

E. Silvi, Esq.

T. Sinonds, Esq.

Messrs. Simpkin, Marshall, Hasiltox, Kent, \& Co., Ltd.

Thomas Simpson, Esq.

Frank B. Simson, Esq.

The Rev, A. C. Sмiтн, M.A.

B. Wood Sirth, Esq. 
ILarold Simte, Esq.

Sir Greville Syyth, Bart.

Major-General F. Е. Sотневу.

Messrs. H. Sotheran \& Co.

Dr. J. H. Stenhouse, R.N.

Miss Maud Stevenson.

John Charles Stewart, Esq.

Sir George Stiriang.

William Stoate, Esq.

J. Henry Stock, Esq.

C. Stonham, Esq.

Mrs. Gerard Streatfield.

Lt.-Colonel C. I. Strong.

P. Stubs, Esq.

Vincent Stuckey, Esq.

Colonel R. W. STUddy.

T. E. Studdy, Esq.

James Sutton, Esq.

Lady Sutton.

A. I. TAtE, Esq.

T. E. Tatton, Esq.

J. B. TAYLOR, Esq.

W. B. Tegetmeier, Esq.

George A. Templer, Esq.

Prof. D'Arcy Thompson, M.A.

J. Thомpson, Esq.

R. Н. Thompson, Esq.

Seton M. Thomson, Esq.

А. Thorburn, Esq.

Mrs. Thornton.

John Gale Thring, Esq., M.A.

Viscount Throwley.

Piers Thursby, Esq.

Lt.-Colonel Thrynse.

F. J. Tilynne, Esqq.
Sir John Tilley, K.C.B.

C. Edmund de Trafford, Esq.

Major H. Tretelyan.

The Rev. Canon Tristram, D.D.,

F.R.S.

J. T. Tristram-Valentine, Esq.

(the late).

The Hon. R. C. Trollope.

Sir Thomas Troubridge, Bart.

J. A. Tulk, Esq. (the late).

The Lord Tweedmouth. (2 copies.)

Edward Maxwell Twopeny, Esq.

H. M. UPCHER, Esq.

Lieut.-Colonel WillovgirbY

Verner, R.B.

B. Wentworth Verron, Esq.

A. R. Verschoyle, Esq.

E. Verschoyle, Esq.

J. ViCARY, Esq.

Captain J. A. M. VIPAN.

Mrs. Vivian.

H. Howard Vyse, Esq.

Colonel A. L. Walker.

Edwin WaLker, Esq.

Mr. Walker.

V. O. Walmesley, Esq.

The Lord Walsingham, F.R.S.

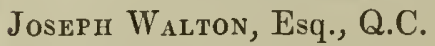

W. H. Warner, Esq.

Messirs. Watkins \& Doncaster.

Godfrey J. Webb, Esç.

Messrs. W. Wesley \& Son.

The Earl of Wharncliffe.

Mr. J. WHELDON. 
J. Whitaker, Esq.

J. Whitehorve, Esq., Q.C.

C. WhyMPer, Esq.

Miss Wтскнам.

Johnson Wilkinson, Esq.

Messrs. Willians \& Norgate.

Mrs. W. A. Wills.

The Rev. Herbert Wilson, M.A.

Mr. Alfred Wilson.

Harold Wilson, Esq.

Mrs. Wise.
H. Witconi, Esq.

Collingwood L. Wood, Esq.

Mrs. John Wood.

R. Woodhouse, Esq.

G. A. Wright, Esq.

Mrs. Henty Wrahas.

J. M. Yates, Esq., Q.C.

J. Young, Esq. (2 copies.)

The Zoolugical Society or

LONDON. 



\section{LIST OF PLATES}

\section{IN VOLUME I.}

\section{To face page \\ Portrait of Lord Lilford. (Frontispiece.)}

1. Golden Eagle. Aquila chrysaetus (Linn.).

Adult . . . . . . . . . . . . $\} 2$

2. Do. Do. Immature

Adult . . . . . . . . . . 3

4. Do. Do. Immature . . . . . . . . . $\} 4$

5. Do. Do, Do

6. White-tailed or Sea-Eagle. Aquila haliaetus

(Linn.). Adult. . . . . . . . . 8

7. Do. Do. Immature . . . . . . . . . 10

8. Osprey. Pandion haliaetus (Linn.) . . . . . 11

9. Common Buzzard. Buteo vulyaris, Leach . . . 16

10. RovgiI-legged Buzzard. Buteo lagopus (J. F. Gmelin) . . . . . . . . . . . . . 19

11. Honey-Buzzard. Pernis apivorus (Linn.) · · · $\} 21$

12. Do. Do.

13. Kite. Milvus regalis (Pall.) . . . . . . . 25

14: Black Kite. Milvus migrans (Boddacrt) . . . 27

15. Gyr Falcon. Falco gyrfalco, Linn. . . . . . 29

16. Iceland Falcon. Fulco islandus, J. F. Gmelin.

Adılt female. . . . . . . . . . . . 31

17. Do. Do. Immature female . . . . . . . 32 
18. Greenland Falcon. Falco candicans, J. F. Gmelin. 36

19. Perearine Falcon. Falco peregrimus, Tunstall. Female, fourth year . . . . . . . . $\} 40$

20. Do. Do. Male, first year . . . . . . . .

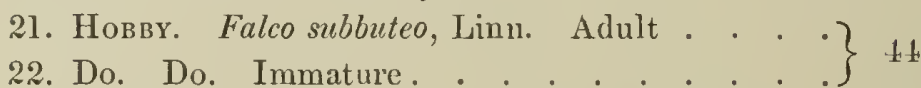

23. Red-fonted Falcon. Falco vespertinus, Linn. . 45

24. Merlin. Falco esalon, Tunstall. Adult male. .
25. Do. Do. Adult female and immature male. . 5

26. Kestrel. Falco tinnunculus, Linn. . . . . . 53

27. Lesser Kestrel. Falco cenchris, Naum. . . . 55

28. Gos-Hawk. Astur palumbarius (Linn.). Adult

female. . . . . . . . . . . . . . 59

29. Do. Do. Plumage of first year . . . . . . 60

30. Sparrow-Hawk. Accipiter nisus (Linm.). Male.

31. Do. Do. Female . . . . . . . . . .

32. Do. Do. Immature male . . . . . $\} 66$

33. Do. Do. Immature female . . . . . . .

34. Marsh-Harrier. Circus aruginosus (Linn.).

Very old male . . . . . . . . . . 67

35. Do. Do. Plumage of first year . . . . . 68

36. Hen-Harrier. Circus cyaneus (Linn.). . . . 69

37. Montagu's Harrier. Circus cineraceus (Montagu).

Adult and immature males ...... . . $\} 73$

38. Do. Do. Female and dark form of male. . .

39. Griffon Vulture. Gyps fulvus, J. F. Gmelin . 77

40. Neophron or Egyptian Vulture. Neophron percnopterus (Linn.) . . . . . . . . 83

41. Tawny, Browr, or Wood-Owl. Syrnium aluco (Linn.) . . . . . . . . . . . 87

42. Do. Do. (Grey race) . . . . . . . . . 88

43. Tengmalis Owl. Nyctala tengmalmi (J. F. Gmelin) . . . . . . . . . . . 89

44. Lowg-eared Owl. Asio otus (Linn.) . . . . 91

45. Short-eared Owl. Asio brachyotus (Forster) • 95 
46. Eagle-Owl. Bubo maximus, Fleming . . . 97

47. Scops OwL. Scops giu (Scop.) . . . . . . 100

48. Little Owr. Athene noctua (Scop.) . . . . 102

49. Hawk-Owl. Surnia funerea (Linn.) . . . . 103

50. Snowy OwL. Nyctea scandiaca (Linn.) . . . 105

51. BarN-OwL. Strix flammea, Linn. . . . . 109 




\section{GOLDEN EAGLE. AQUILA CHRY'SAËTOS (Linn.).}

Falco chrysaëtos, Linn. S. N. i. p. 125 (1766).

Falco fulvus, Naum. i. p. 208.

Aquila chrysaëtus, Macg. iii. p. 204; Yarr. ed. 4, i. p. 11;

Dresser, v. p. 533.

Aquila chrysaëtos, Hewitson, i. p. 8.

Grand Aigle, Aigle doré, French; Stein-Adler, German; Aguila real, Aguila negra, Aguila serrana, Spanish.

This fine species, owing to the enlightened protection of a few landed proprietors and lessees of deer-forests, still brceds in the Highlands of Scotland, and, I believe, in some of the mountain-ranges of Ireland; but its numbers have been greatly curtailed by the high price set upon its eggs by collectors, and the persecution of game-preservers. It is recorded to have bred formerly in various parts of England and in North Walcs, but has long ceased to do so, and is now a very rare visitor to any part of Great Britain south of the border. The nest is usually situated on a ledge of rock, in some cases easily accessible, not infrequently in high trees, and the same site is annually used. 'The eggs are generally three in number, but it is seldom that more than two arc hatched. In Scotland, as far as iny owl experience goes, the principal food of this Eagle consists of Blue or Alpine Harcs, and Rabbits, very young Lambs, and carrion.

Some gamekeepers declare that the Eagles are very destructive to Grouse; but I only once, in Scotland, saw one of this species in actual pursuit of any bird, in this case a Ptarmigan was the object.

'The drawing for the accompanying Plate was taken in 1888 from a pair of birds in the aviary at Lilford, which were taken from a ncst in Scotland in 1877, and laid eggs for the first time in the year first mentioned. 


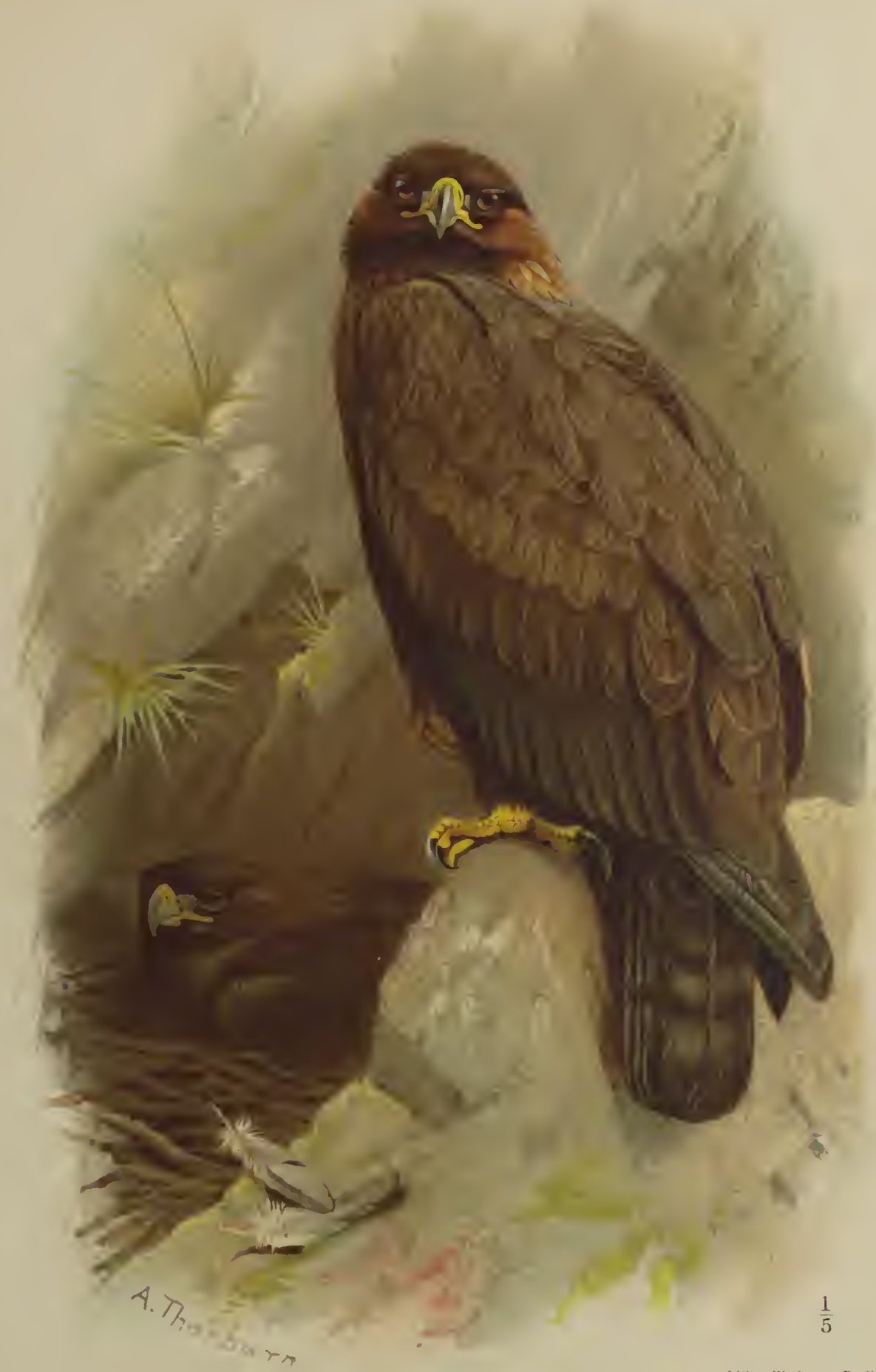

GOLDEN EAGLE.

Aquila chrysaētus (Limn.) 



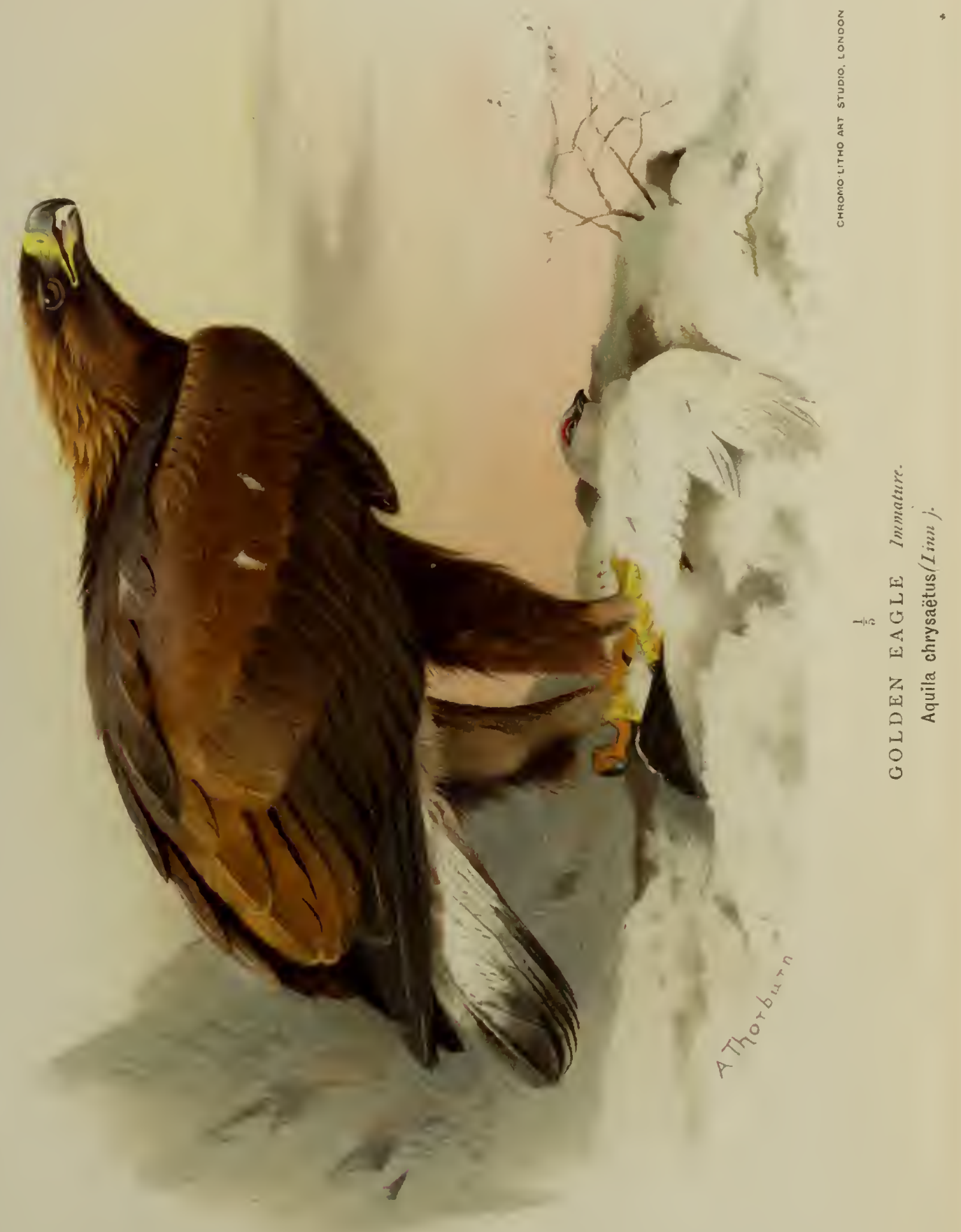





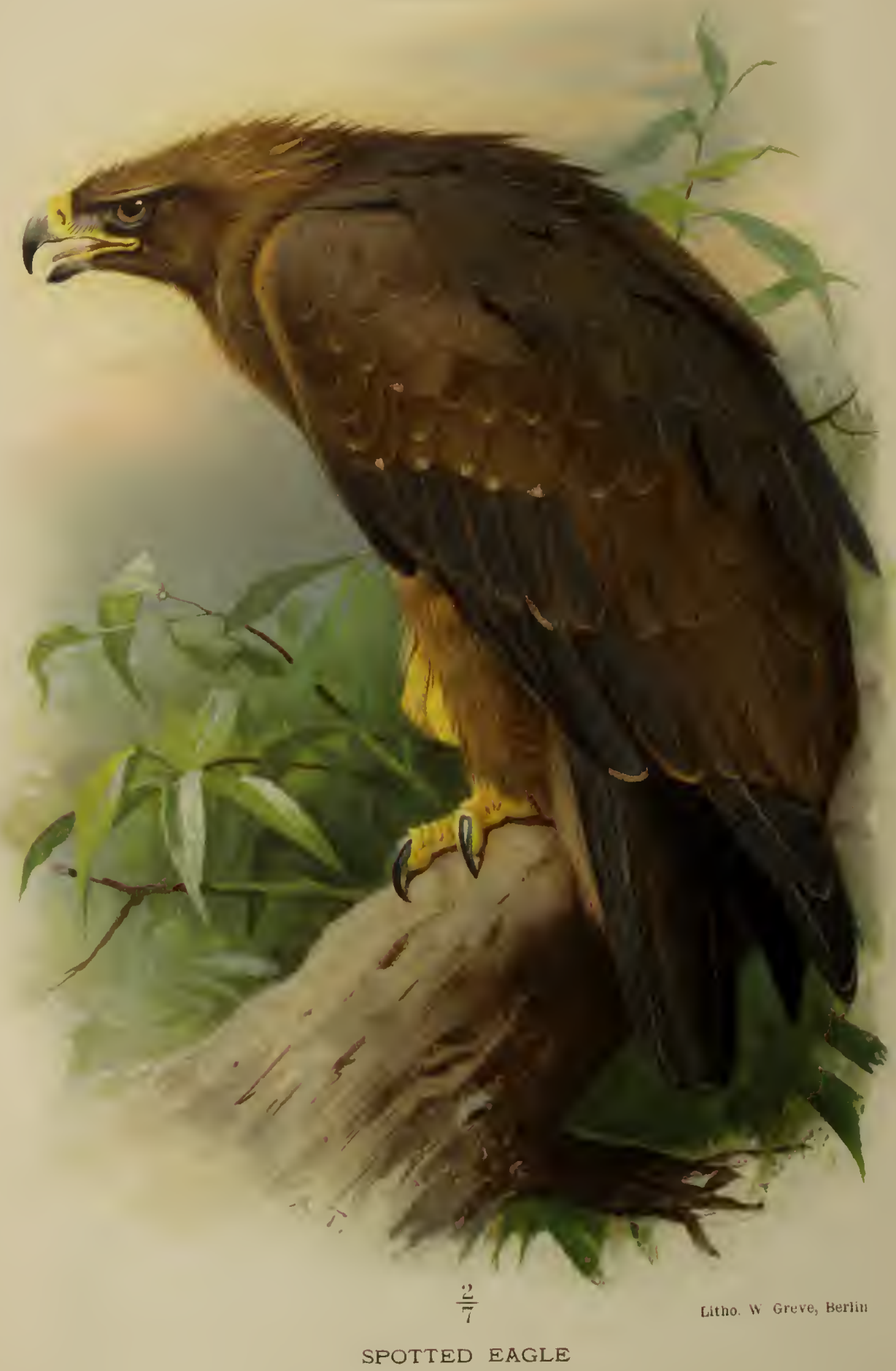

Aquila nevia (J., F. Gmelin).

Drav'n from life it lalford. Plumayp of fourth yent 


\title{
SPOTTED EAGLE.
}

\author{
AQUILA NAVIA (J. F. Gmelin).
}

Falco nævius, Gmelin, Syst. Nat. i. p. 258 (1788).

Aquila nævia, Hewitson, i. p. 18; Yarr. ed. 4, i. p. 20.

Falco clanga, Naum. xiii. p. 40.

Aquila clanga, Dresser, v. p. 499.

Aigle tacheté, Aigle criard, French; Schrei-Adler, German ; Aguila pintada, Valencia.

Few European birds have caused more discussion and confusion amongst ornithologists than the Spotted Eagle and its close congeners; I have no wish to add any elements for argument on this well-worn subject, and will therefore only state that, in my own opinion, we have in Europe only one true species of the Eagle that is called "Spotted," although I am perfectly ready to admit that this species may be fairly divided into two separate forms or races.

My business here is to give representations of Spotted Eagles obtained in this country, and with this object I have chosen two specimens of (probably) about the same age, obtained in October and November 1891, in Essex and Suffolk respectively, and differing widely in plumage.

Mr. H. Saunders, in his most useful 'Manual,' 
records six occurrences of the Spotted Eagle in our Islands; to these I can add one killed at Somerley, Hants, on December 28, 1861, and three obtained in the late autumn of $189 \mathrm{l}$ in East Anglia. My Plates are taken from two of these last three birds, the darkcoloured one from a living specimen captured near Colchester in October 1891; for the opportunity of giving the portrait of this specimen from life, I am indebted to the courtesy of the Hon. Walter Rothschild.

The bird represented in the other Plate was killed near Wickham Market in November 1891, stuffed by Messrs. Pratt, of Brighton, and very kindly lent to me by its owner, Mr. J. J. Hornby, for the purposes of this work; this is one of the finest specimens of this Eagle in the spotted stage of plumage that I have ever seen, but a third specimen killed at Leigh Court, Essex, early in November 1891, of which Mr. Thorburn was, at my request, allowed to make a drawing, is very nearly as beautiful. I became well acquainted with this species during my constant shooting expeditions in Epirus and Albania in 1856, 1857, and 1858. I believe that it breeds in the former province, as it certainly does, or did, in Acariania, but I never found an occupied nest near the coast.

In the winter months we found this species very abundantly, in fact it might fairly be called the Eagle of Epirus, although by 110 means the only representative of the genus Aquila therein. The favourite resorts of the Spotted Eagle are marshy but well wooded plains, and in my experience almost every clump of high trees on our favourite shooting-grounds was tenanted by one or 


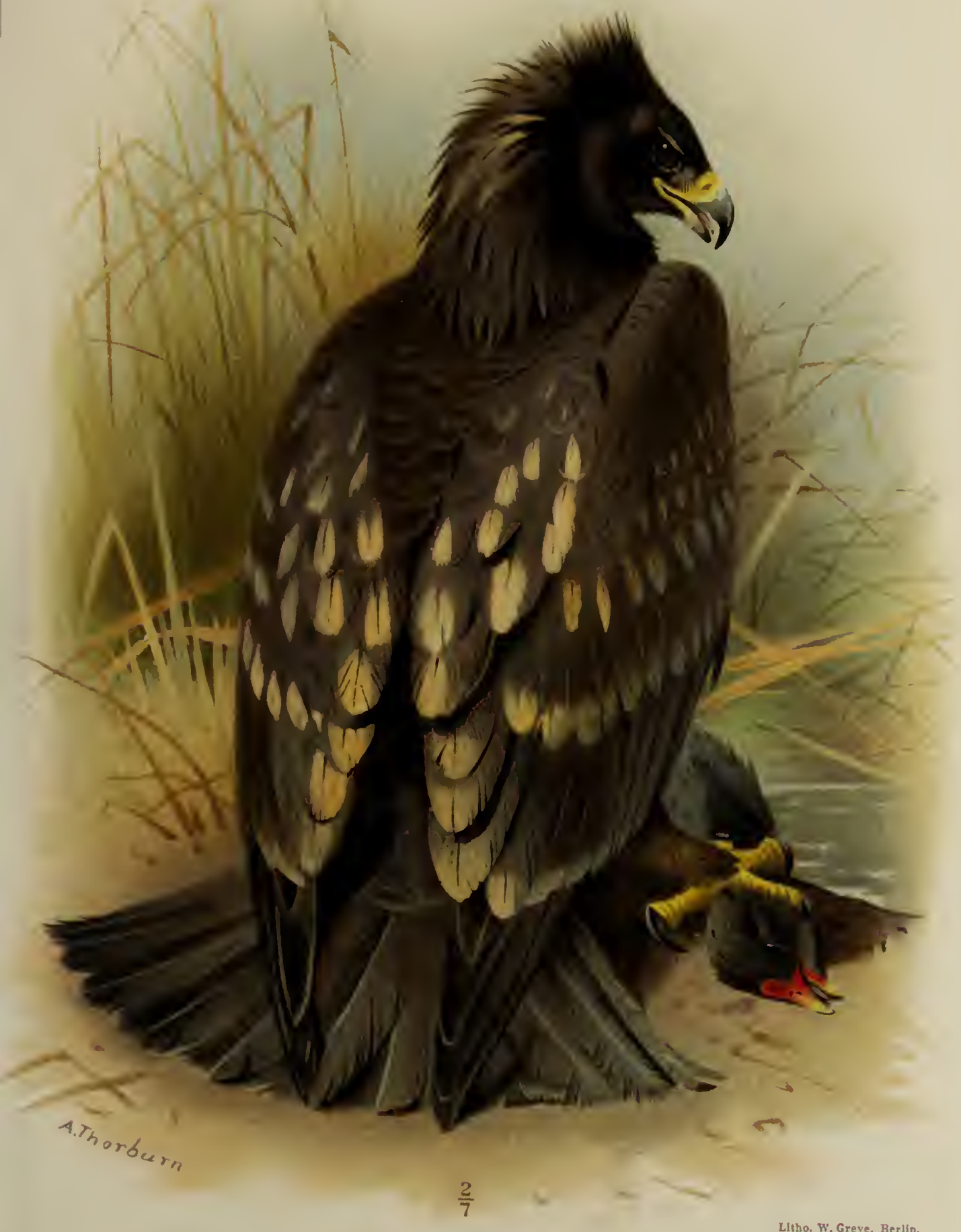

Lltho. W. Greve, Berlin.

SPOTTED EAGLE.

Aquila navia (J. F. Gmelin),

Drawn from a living specimen captured near Colchester, Oct. 29th. $189 \mathrm{~g}$. 



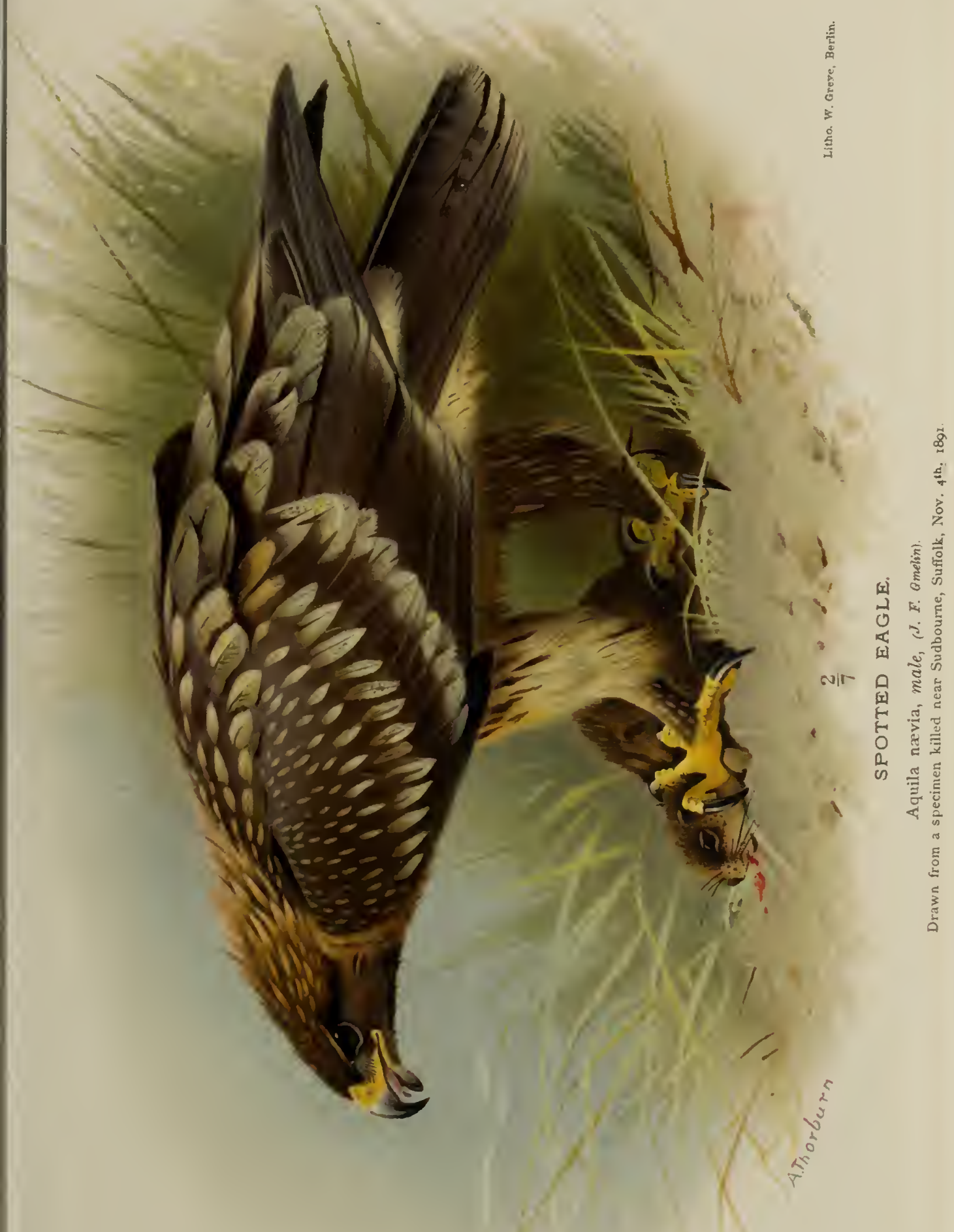



more of these birds from October till March or April. In general habits I could perceive but little difference between this Eagle and the Common Buzzard, except that the former birds very frequently followed us, or kept flying from tree to tree upon our flanks, as we tramped the country with our guns, but I must admit that I never saw a Spotted Eagle in pursuit of any bird, even of a wounded one. My impression is that during the winter months these Eagles feed principally upon small mammalia and marsh-frequenting birds that they can take upon the ground, such as Waterhens and Rails, and I can vouch for the fact that in spring, at all events in European Turkey, frogs and small snakes form their staple diet. The usual cry of this Eagle is a shrill frequently repeated double note, but I have occasionally heard them utter a long scream. To those who are not well acquaintcd with this species, I may state, roughly spcaking, that the spots are lost with advancing years, and that the plumage of adults is of a more or less uniform dark brown. I have kept several Spotted Eagles in captivity at Lilford and find them very peaceable and friendly inter se. It will be noticed that I have treated both races of this Eaglc as constituting one species, one of my principal reasons for so doing being that their cries are absolutely identical. I have never secn the Spotted Eagle alive in Spain, but have received specimens from Andalucia and Valencia, and noticed one making a stoop at something on the ground within a milc of the Bidnsoa on the French side of that famous river. I lave a very beautiful specimen of this Eagle obtaincd ncar Nicc in 1858. 
The third Plate represents an adult bird, and was taken from a living specimen at Lilford; this bird was purchased from a London dealer, who assured me that he had received it from N. Germany. 



\title{
WHITE-TAILED OR SEA-EAGLE.
}

\author{
HALIAËTUS ALBICILLA (Linn.).
}

Vultur albiulla (misprint), Linn. S. N. i. p. 123 (1766).

Falco albicilla, Naum. i. p. 224.

Haliaëtus albicilla, Macg. iii. p. 221 ; Dresser, v. p. 551.

Aquila albicilla, Hewitson, i. p. 15.

Haliæctus albicilla, Yarr. ed. 4, i. p. 25.

Pygargue ordinaire, Frenclı; See-Adler, German; Aguila de Mar, Spanish.

This bird, which is perhaps more commonly known as Sea-Eagle, formerly bred in many parts of Scotland and Ireland, but its numbers have been so greatly reduced by the persecution of game'zeepers and shepherds, that I believe that I am justified in saying that very few pairs, probably not a dozen altogether, now nest regularly in the United Kingdom ; and as I shonld be very unwilling to be the cause of the further molestation or destruction of this fine species, I refrain from publishing the very little that I know concerning its nesting-localities in our country. The nest of this Eagle in our islands is generally, but by no means invariably, placed on a ledge of sea-cliff, and is usually more or less difficult of access; but, in localities where the bird is 


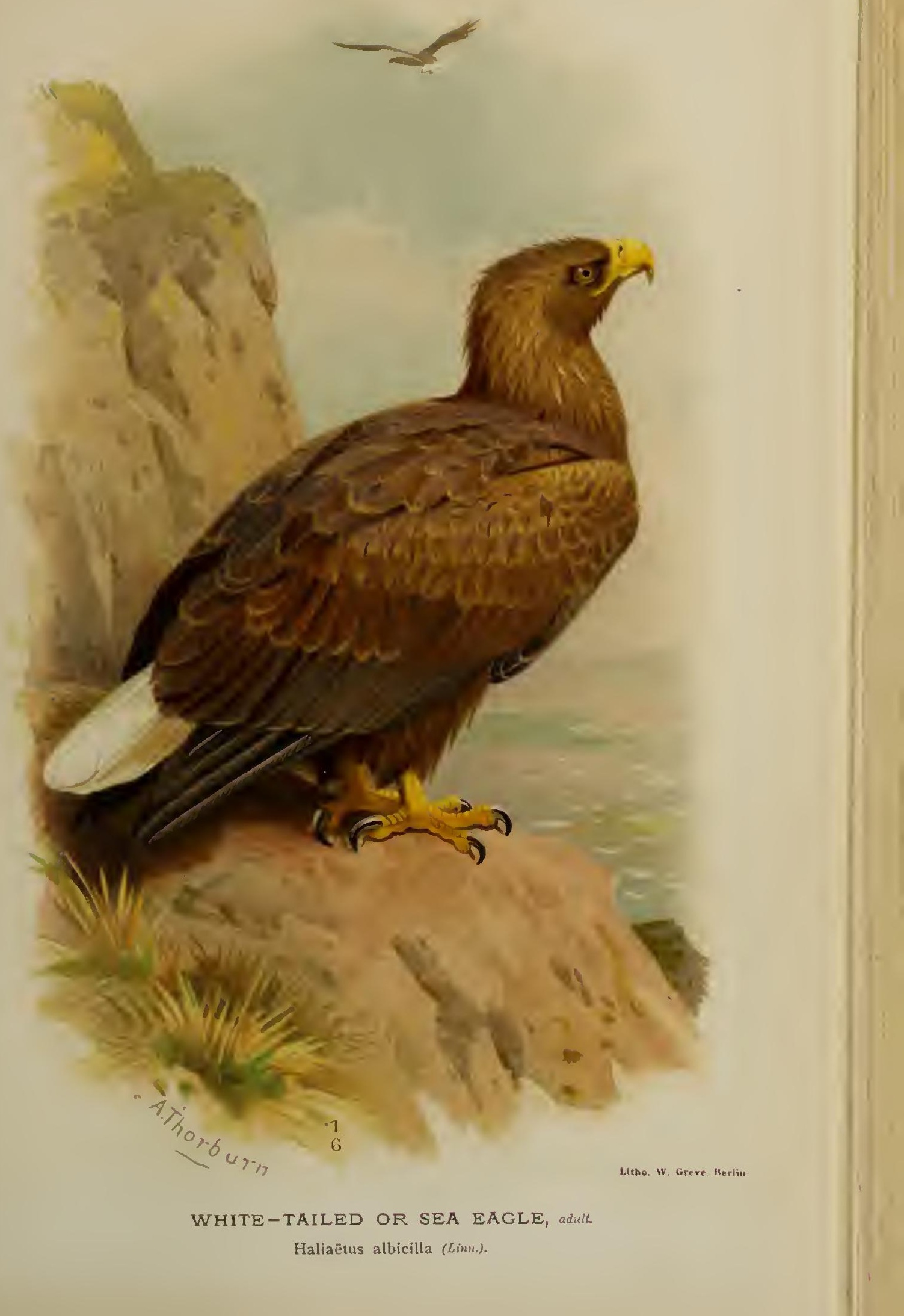



comparatively unmolested, the nest is often to be met with on trees, sometimes on bushes, and occasionally even on the ground; it is built of sticks, piled on year aftel year as the exigencies of time and weather may require, and lined with grasses, moss, and fern. John Woller, as quoted in the 4 th edition of Yarrell, sars that, in the many nests of this species found by him in Scotland, Luzula sylcatica mas always made use of, but I never had the good fortune to see a nest at close quarters in that country. 'The eggs are generally laid in March, two in number, and are pure white. Immature birds of this species are rery frequently met with in autumn and winter on the east coast of England, and not rery uncommonly inland, and are easily shot or trapped; in a great many instances these occurrences are recorded in the local nerspapers as those of "Magnificent Golden Eagles which have been devastating f.c. fc." These mandering Eagles, as a matter of fact, subsist principally upon rabbits and any dead animal substances that they can find. I have seen this bird several times in Scotland, more frequently on the west coast of Ireland, and often on the 'Turkish shores of the Adriatic; in the latter localities it seemed to prey principally upon white mullet and bass captured in the shallow bars and lagoons, and also to a great extent on the carcases of cattle left to rot on the plains. I have also, on sereral occasions, seen a White-tailed Eagle stoop at swimming water-fowl, but only once witnessed a capture of this kind; the old Eagles were generally observed either sitting motionless on a dead bough of some lofty trce in the marshes, or soaring high in the 
air playing with one another and uttering from time to time a sharp yelp or bark. The first Plate represents a specimen in the plumage of the first or second year; the second, in adult plumage, was taken from a sketch of an old female sent to me from a nest in Ireland in 1854, and still alive in good health and plumage at Lilford, February 1890.

The Highland shepherds accuse the White-tailed Eagle of destroying many lambs, and there is, I fear, no doubt that the accusation is well founded; but in Epirus I was begged by some of the pastoral and more or less brigand fraternity to spare the old birds at a nest on the shores of the Gulf of Arta, on account of their services in driving away other birds of prey; these individuals, however, were Greeks, and probably lied, and, although I scrupulously attended to their request, I am inclined to think that it was based on some superstition rather than on the reason alleged. 


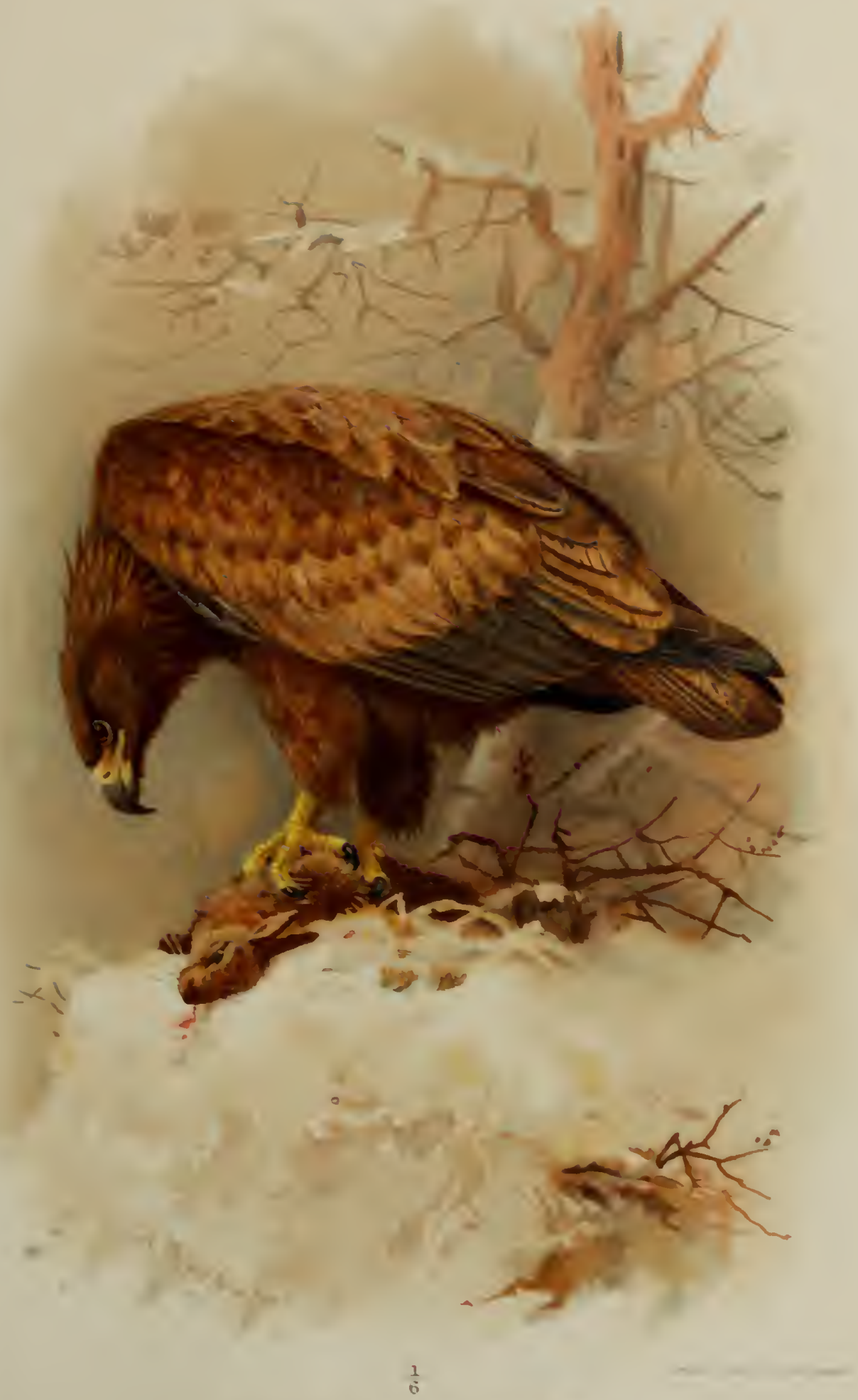

WHITE-TAILED CR SEA EAGLE. Hallaetus altiolla $:-1$ 



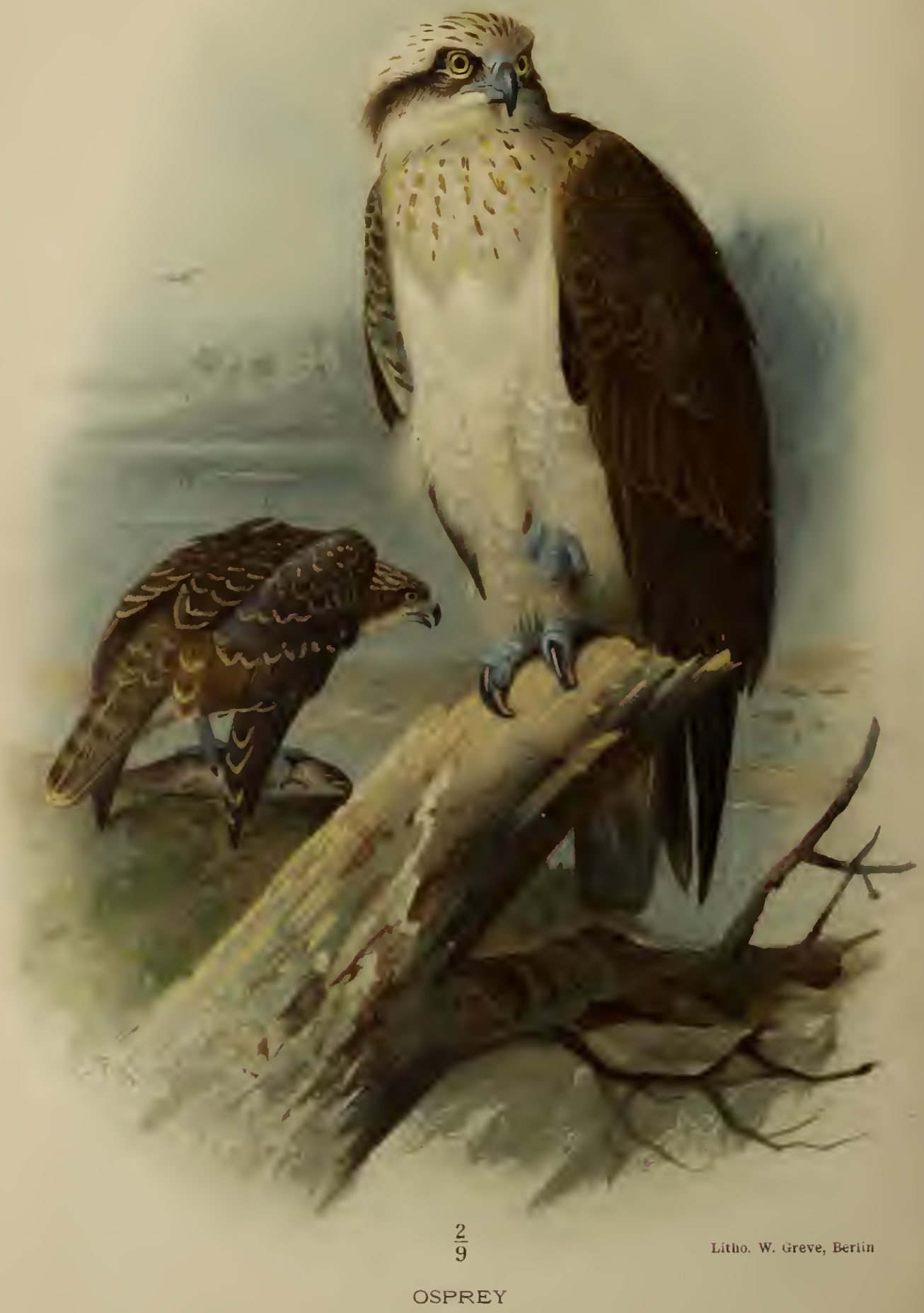

Pandion haliaëtus (Lim.). 


\section{OSPREY. \\ PANDION HALIAËTUS (Linn.).}

Falco haliætus, Linn. S. N. i. p. 129 (1766).

Falco haliaëtos, Naum. i. p. 241.

Pandion haliaëtus, Macg. iii. p. 239; Dresser, vi. p. 139.

Pandion haliæetus, Hewitson, i. p. 19 ; Yarr. ed. 4, i. p. 30.

Balbusard, French; Fluss-Adler, Fisch-Adler, German ; Aguila pescadór, Spanish.

These beautiful birds visit Great Britain in March, and are too often massacred during their short stay on the English estuaries on their way to their nestinghaunts in Scotland and Northern Europe. In 1832 Sir William Jardine, as quoted in Yarrell's 'British Birds,' wrote that a pair or two might be found about most of the Highland Lochs, where they built either on ruined towers or aged trees. Between 1849 and $1857 \mathrm{Mr}$. Wolley found that so many Ospreys had been destroyed in the Scottish Highlands that most of their recorded breeding-places were descrted, and at the present day a very few pairs only annually breed there under strict and most laudable protcction.

The Osprey returns southwards about the beginning of Septcmber, and on both passages frequently follows the course of rivers to a considerable distance from 
the sea. I am acquainted with several occurrences in our county-Northamptonshire, Oxfordshire, and, if my memory serves me correctly, more than one in Warwickshire, and on one occasion had the great delight of watching an Osprey fishing at his ease, though without success, on a broad reach of our principal river, the Nen. My earliest acquaintance with this species was made upon the shores of the Lake of Geneva, near Lausanne, where, in March and early April, one or two were constantly to be seen sailing at no great height above the water, and occasionally dashing at the fishes that frequentcd it; so far as I could then make out, small perch were the most frequent victims. I have subsequently met with Ospreys throughout the Mediterranean, from Gibraltar to the Ionian Islands and the adjacent Turkish mainland. A pair of these birds nested regularly, and may, for all that I know to the contrary, do so still, on the Mediterranean side of the Rock of Gibraltar; Colonel Irby showed me this nest in June 1869, when it contained young, and he has published some interesting details with reference to the Osprey and its habits in that part of the world in his exhaustive work on the 'Ornithology of the Straits of Gibraltar.' I know of several nesting-places of the Osprey on certain Mediterranean islands, and feel no doubt that a pair constantly observed by us in May 1876 about the harbour of Santander had a nest in that ncighbourhood, although we failed to discover it. From my experience I think that the Osprey prefers the bare limb of a ligh tree, or the top of a post or 
fishing-stake, to a rock, for taking its meals upon; but, of course, when the captured fish is heavy the birds avail themselves of the first convenient dinnertable, and I have more than once seen them aliglit with their prey on the bare sandy shore. In the case of large fishes I think that the Osprey seldom touches the head, and certainly avoids the larger bones. I have found the almost entire skeletons of large mullets with heads and tails intact, but with every scrap of flesh and skin devoured by our birds.

The appearance of the Osprey on wing is most singularly graceful, the long and, comparatively speaking, narrow wings, and the peculiar angle at which they are spread whilst the bird is bunting for its prey, distinguish it at any distance from any other European species. Althongh this bird very frequently hovers for a second or two before making its stoop, it generally dashes at its 'quarry' from a certain height, and often seems simply to lift it from the water in its talons. On the other hand, it is common to see the Osprey plunge headlong below the surface for an instant; I need hardly say that it does not pursue fishes under water. The method of the Osprey differs from that of the Falcons in this particular, that whereas the latter birds on missing their quarry at the first stoop almost invariably mount before making a second, the present bird, if its intended victim moves during the stoop, checks its flight for a moment and makes anotler attempt from the lower "pitch." I trust that my readers will pardon my use of the technical terms of falconry in treating of a fish-eating bird, but I can 
find no others equally expressive, and I flatter myself that my meaning in this instance must be clear enough. For obvious reasons the Osprey prefers shallow waters for its operations, and the great lagoons of Sardinia, Corsica, and Tunis are especially favourite resorts. This bird generally builds a liuge nest of sticks: I have never looked into one except when crowded with young birds, but I am inclined to think that the few that I have seen were capped or lined with fragments of sea-weed. The eggs are usually three in number, and are certainly amongst the most beautiful of those of British birds. I have found it impossible to keep this species alive in captivity for any length of time. It is perhaps unnecessary, but will not occupy much space, to inform my fair readers that the "Osprey" of the plumassiers and lat and bonnet makers has nothing to do with the present bird, but is applied to the plumes of various species of the Egret-family, used by unreasoning womankind too frequently as aids to natural attraction. 



\title{
COMYON BUZZARD.
}

\author{
BUTEO VULGARIS, Leach.
}

Buteo rulgaris, Leach, Srst. Cat. Mamm. \& Birds in Brit.

Mus. p. 10 (1816); Hewitson, i. p. 38; Yarr. ed. 4, i.

p. 109 ; Dresser, v. p. 449.

Falco buteo, Linn. S. N. i. p. 127 ; Naum. i. p. 346.

Buteo fuscus, $\mathrm{Macg}$. iii. p. $] 83$.

Buse, French ; Bussard, Mäuse-Bussard, German; Arpella, Spanish.

The Buzzard was formerly common and well known throughout England, Wales, and Scotland, and in Thompson's time was also to be met with in certain localities in Ireland; but although it still holds its own in some of the wilder districts of our country, its numbers have been very greatly reduced by trapping and shooting, and in the agricultural parts of England it may fairly now be called a rare bird. I am personally acquainted with several nesting-places of this species in England and Scotland; the nest is generally built on cliffs, or tall trees, and is composed of sticks and twigs, with wool and dried grass as lining; the eggs, generally three in number, are white, with spots and streaks of rusty red-brown. 


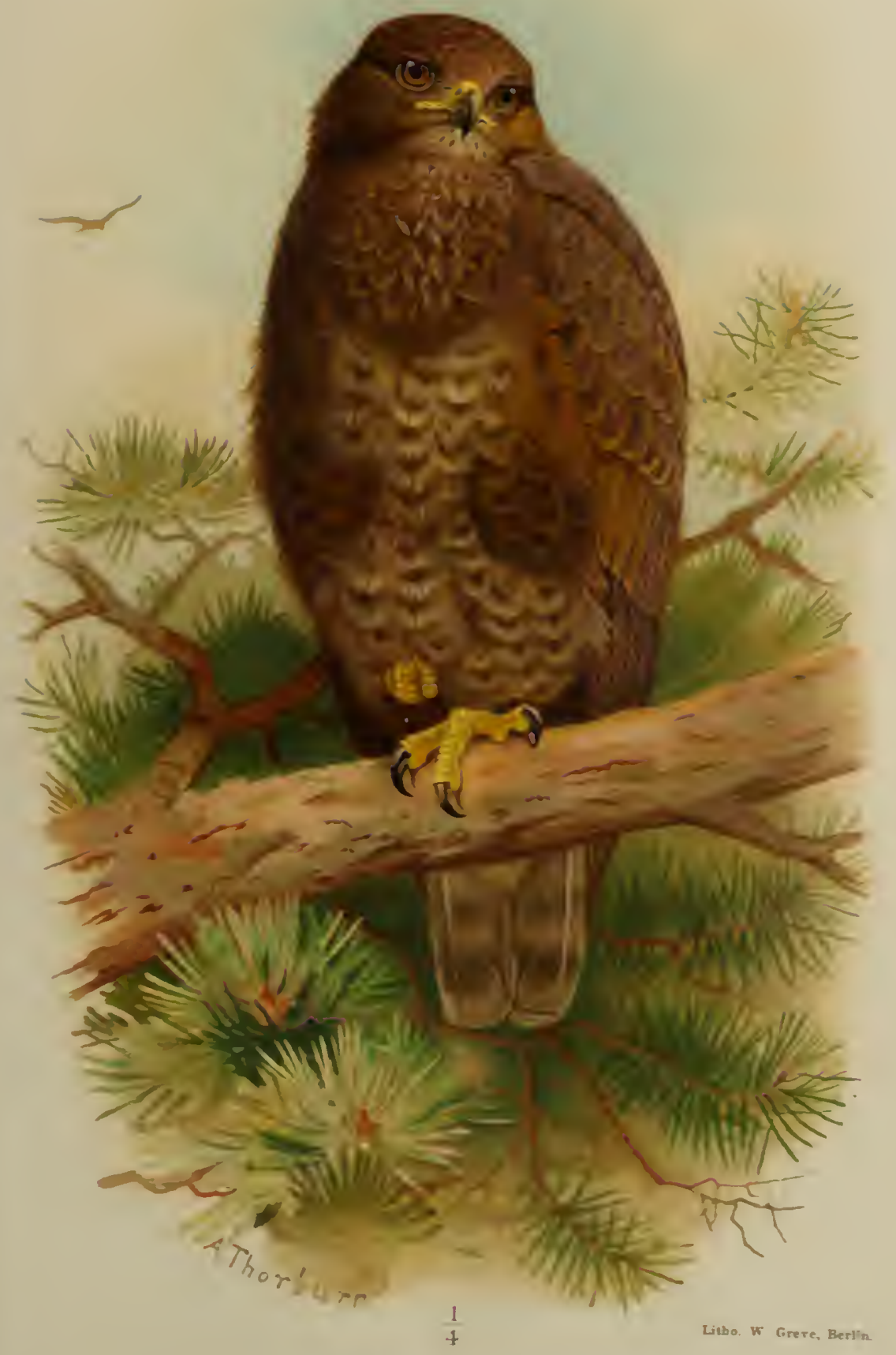

COMMON BUZZARD

Buteo vulgaris, Leorh. 
In general habits the Buzzard much resembles the Eagles, especially in its common habit of soaring at a great height in fine weather, and in the wilder parts of Scotland this bird is constantly pointed out to tourists as an Eagle. I believe that the Buzzard feeds principally upon moles, rats, mice, voles, and young rabbits; no doubt a young or sickly chicken may be occasionally taken by these birds, but on the whole they should in my opinion be strictly preserved and encouraged, as not only very useful but most ornamental. The cry of the Buzzard is a plaintive wail, and is constantly uttered by the parent birds as they sail over thcir nests when disturbed.

This species ranges over the greater part of Europe; I met with it constantly during the winter on the shores of thc Lake of Geneva, wherc, for some reason of which I could not obtain any satisfactory explanation, it was generally known to the country people under the name of "Bon Oiscau"; as many of my readers are doubtless aware, the word "bon" is occasionally used to imply simple, or stupid, but in this instance I am disposed to think that the thrifty Swiss recognized the utility of the bird and applied the adjective in its primary sense, though the Buzzard certainly is in a measure comparatircly simple-minded about traps, and in allowing the ncar approach of human enemies. In captivity the Buzzard becomes perfectly tame, and if woll fed may safcly be trusted in the company of almost any other birds.

Tlis spccies is subject to many variations of plumage; thic subject selected for the Plate is a very remarkably 
dark-coloured specimen, which was taken in Cornwall more than twenty years ago and is still alive at Lilford; this bird has altered very slightly in plumage since it came into my possession, and has a peculiar purple bloom upon its feathers which Mr. Thorburn has done his best to render faithfully, and, in my opinion, has succeeded admirably in treating what must have been an exceptionally difficult detail. 



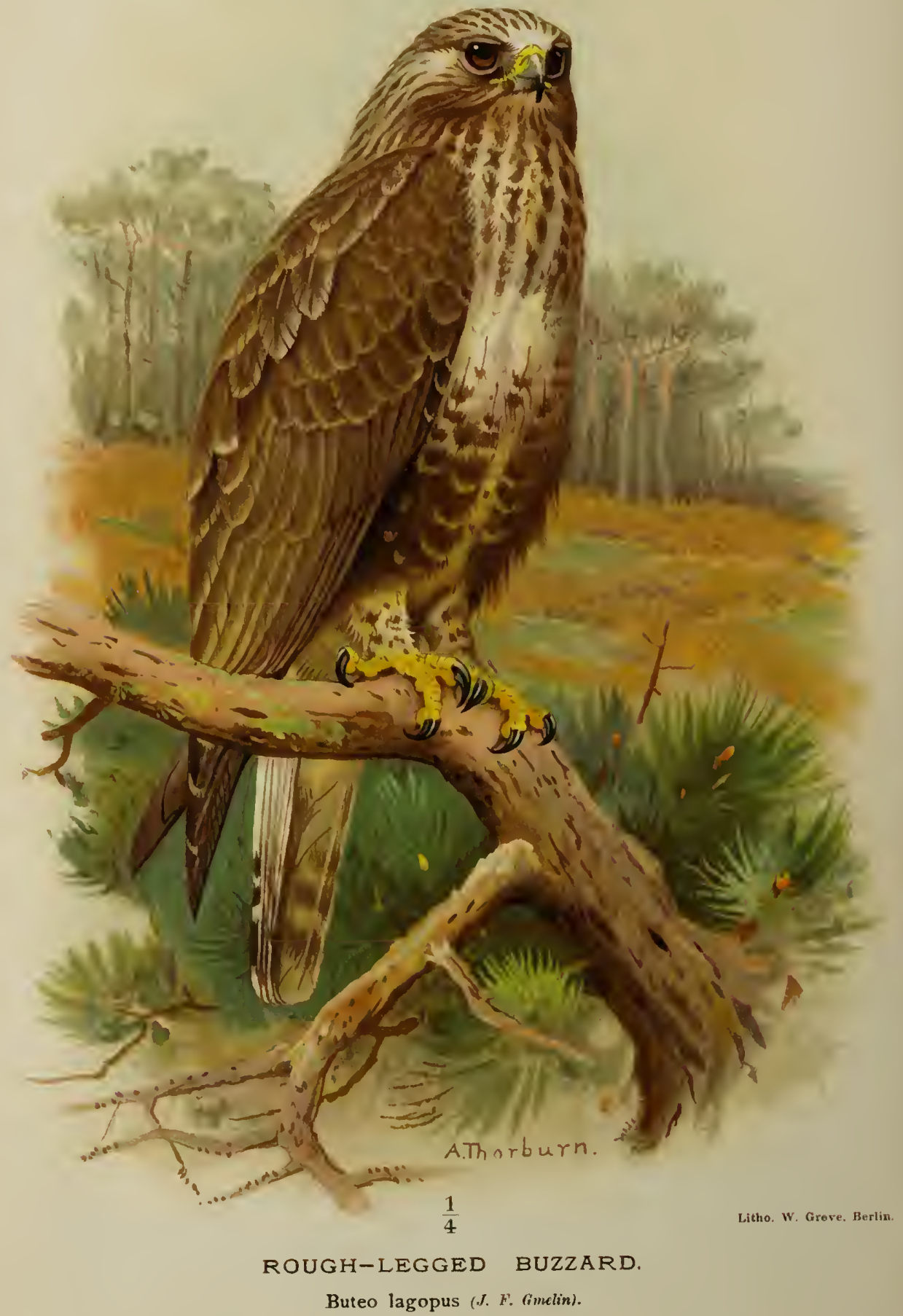




\title{
ROUGH-LEGGED BUZZARD.
}

\author{
BUTEO LAGOPUS (J. F. Gmelin).
}

Falco lagopus, Gmelin, Syst. Nat. i. p. 260 (1788); Naum. i. p. 359.

Buteo lagopus, Macg. iii. p. 193; Hewitson, i. p. 39 ; Yarr. ed. 4, i. p. 115.

Archibuteo lagopus, Dresser, v. p. 471.

Archibuse pattue, French ; Rauchfuss-Bussard, German.

This is a species about which I am unable to give any information from personal observation of its habits in a wild state, as I have not seen more than pcrhaps four or five individuals at various times swecping over the open country of West Norfolk in late autumn and winter.

'I'he Rougll-legged Buzzard breeds commonly in the north of continental Europe, and is by no means an infrequent autumnal visitor to Great Britain, where it is generally destroyed very soon after its first appearance; it ccrtainly prefers open to wooded country during its visits, and has a very natural predilection for rabbitwarrens; otherwise, in general liabits, it seems to resemble the Common Buzzard, but it is a larger and much more powerful bird, and may he distingnished 
from that species even at a considerable distance by its lighter colour. The few reports of this bird's having bred in our country are open to very considerable doubt.

The figure here given was taken from a bird now alive at Lilford, where it has been for several years; it is a very silent bird, and lives in perfect amity with various other raptorial species. 



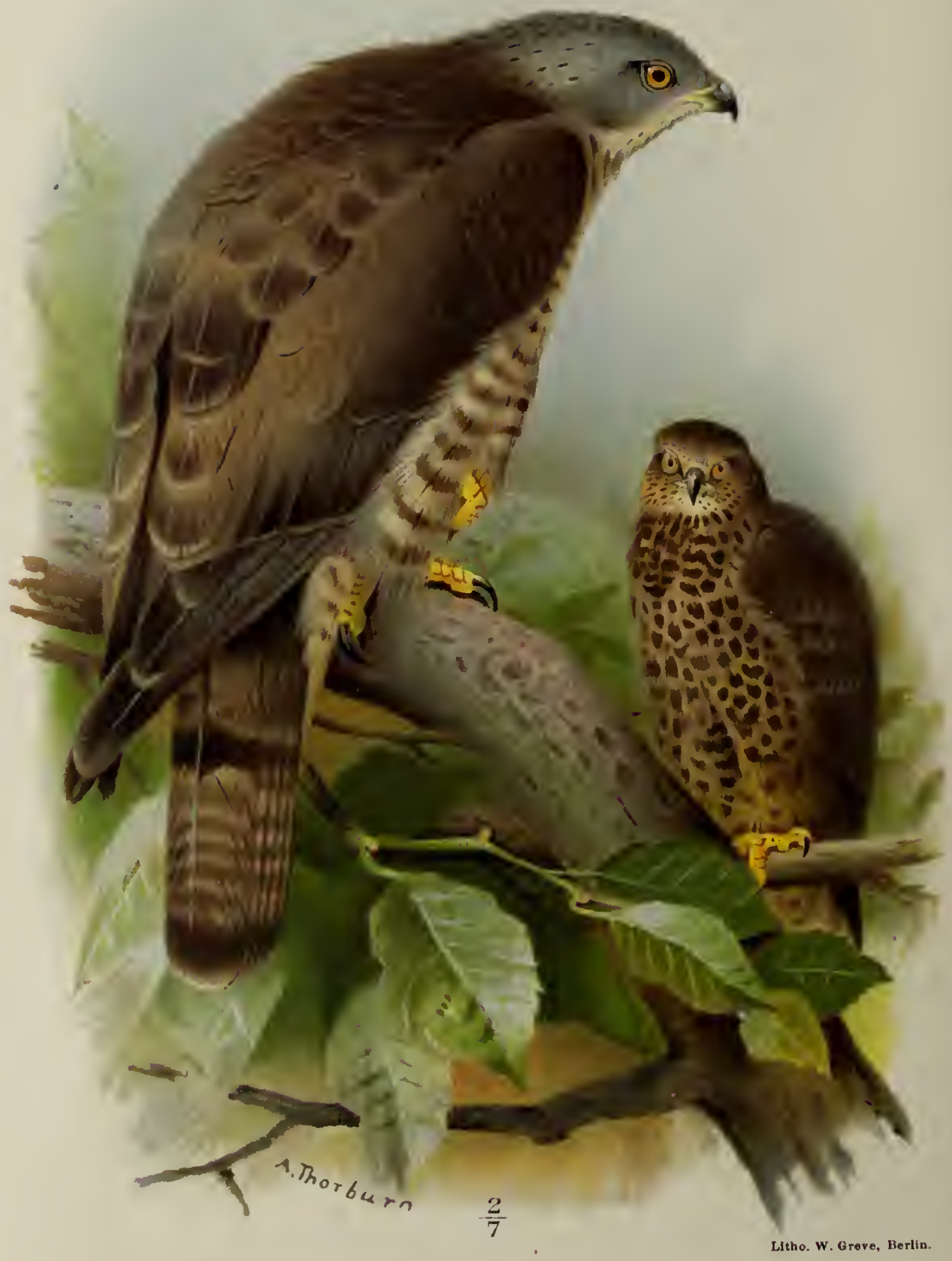

HONEY-BUZZARD.

Pernis apivorus (Limn.). 


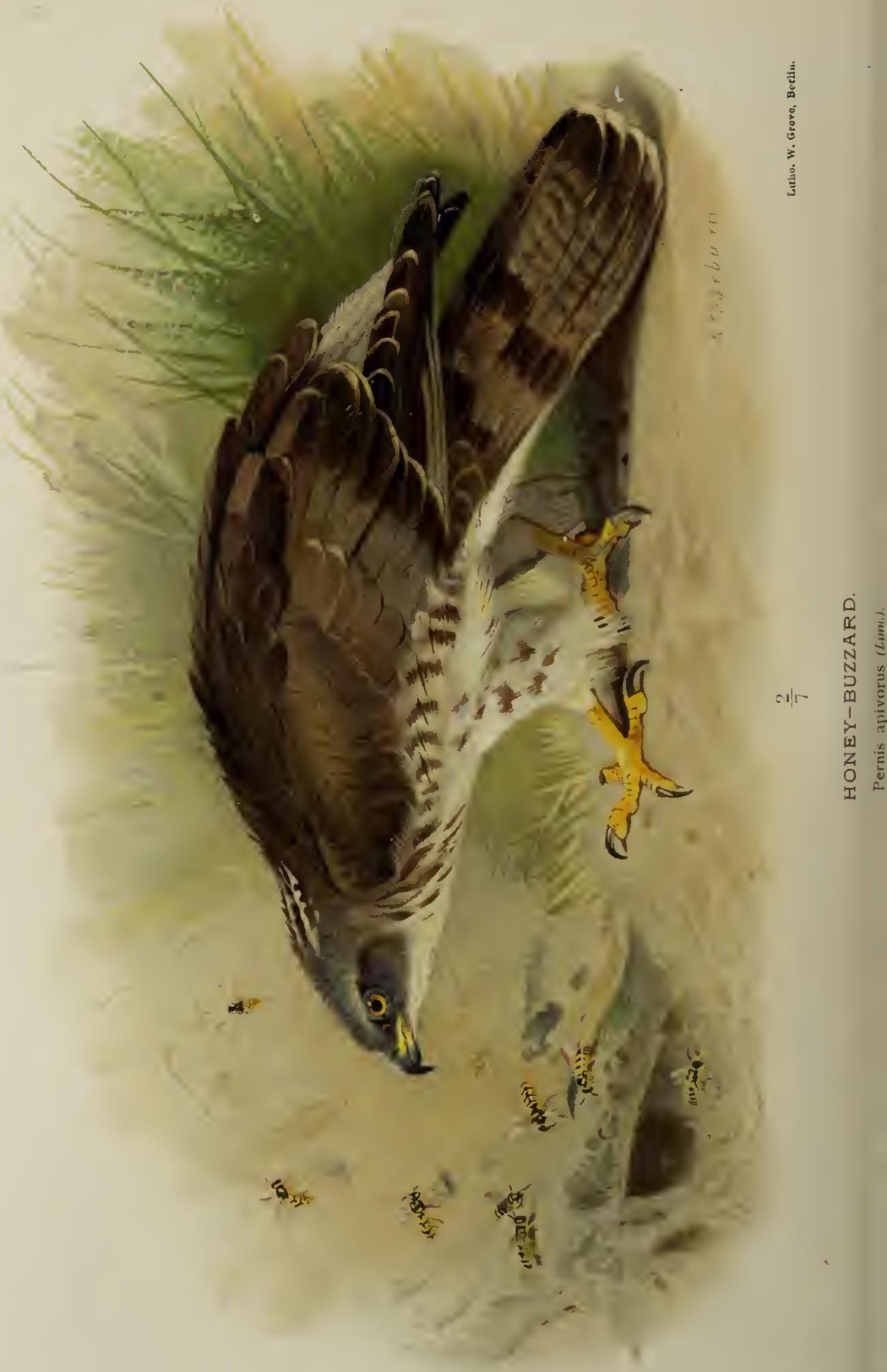




\section{HONEY-BUZZARD.}

PERNIS APIVORUS (Linn.).

Faleo apivorus, Linn. S. N. i. p. 130 (1766) ; Naum. i. p.367, xiii. p. 28.

Pernis apivora, Macg. iii. p. 254.

Pernis apivorus, Hewitson, i. p. 40 ; Yarr. ed. 4, i. p. 121 ;

Dresser, vi. p. 3.

Buse bondrée, Freneh; Wespen-Bussard, German; Aguila de Moros, Abejero, Abispera, Spanish.

This bird, whose common English name should be summarily changed to "Wasp-Buzzard," is locally wcll known as a summer visitor to the forest-districts of most parts of Europe. My friend Mr. H. E. Dresser, in his grand work 'The Birds of Europe,' records it as breeding in Finland; it is exceedingly common on passage in Sicily, it occurs in Palcstine, and we found it nesting on the frontiers of Santander and Asturias. In this country thcre are many records of the finding of occupied nests of the Honey-Buzzard; I am glad to be able, on good authority, to add to those recorded in the 4th ed. of 'Yarrell,' two instances in the county of Bucks; and I have every reason to bclieve that if unmolcsted these birds would breed in some abundance throughout our British woodlands. In 
Northamptonshire I have very good traditional evidence that it was by no means uncommon in the summer during the early decades of the present century, and I have a specimen that was shot with its mate from a nest that contained four eggs, in the summer of 1843 or 1844. The old gamekeeper who shot these birds declared that in his early days he had shot "scores of Buzzards of two kinds," besides Kites and Harriers.

My personal acquaintance with the subject of this article in freedom is somewhat limited, being confined almost exclusively to Switzerland and Spain. I seldom, if ever, observed a Honey-Buzzard soaring in the manner of the Common Buzzard or Kite; it always seemed to me to be a somewhat sluggish bird, by no means remarkably shy of man, delighting in "taking the sun" on the topmost boughs of lofty trees, and evincing a very marked preference for beeches. It is very frequently to be seen on the ground in open glades under the forest trees, in search of wasp-grubs and other food, and runs with great ease and rapidity. The only note that I have heard from a wild bird of this species is a shrill monosyllabic squeal rapidly repeated, and very distinct from the long-drawn shriek of the Kite or the wail of the Common Buzzard. The nest is usually placed in a tall beech or oak tree, at a cousiderable heiglit from the ground, and is usually composed of dead sticks, and lined with twigs and root-fibres, and carpeted with fresh beech-leaves that are constantly renewed till the eggs are hatched out. The story of the leafy screen that is recorded in 'Yarrell,' 4th ed. vol. i. p. 123, on the authority of the late Mr. E. Clough 
Newcome, was told to me by that gentleman many years ago ; his idea was that it was intended either as a means of concealing the nestlings from the sharp cycs of the Gos-Hawks that frequent the forest in which he observed this habit, or as a screen from the sun; be this as it may, it is not an invariable custom, and, so far as the latter hypothesis is concerned, the HoneyBuzzard's nests are generally well shaded from the sun.

Besides the grubs of wasps and bees that constitute the favourite food of this bird, worms, caterpillars, frogs, field-mice, and other "small deer," to my knowledge, come frequently into its bill of fare. It is somewhat remarkable that laving failed in several instances to keep this species alive through the winter upon the ordinary food of "Raptores," I was induced, in the casc of two young birds received from France in August 1892, to try them with an exclusive diet of bread and milk, and found that they did perfectly well upon this very unnatural provend, preferring it even to wasp-comb full of grubs.

I have this ycar (1893) received a nestling of this species (also from France) of the very beautiful variety with white hcad and upper breast, figured in Dresser's 'Birds of Europe' and Borrer's 'Birds of Sussex.' Having been informed in 1891 of the capture of a Honey-Buzzard many ycars before that date in Salcey Forest, Northamptonshire, I wrote to the person named to me as the captor, and reccived the following reply :"Salcey Forest, March 25, 1891. I beg to say, in answer to your letter, that the Honcy-Buzzard was pullicd out by me in the Crown Woods near Silverstone 
in this county in September 1861. On seeing the wasps unusually busy one morning about 8 o'clock, I went near the nest to ascertain the cause. The whole of the combs were scratched out, and there was a hole nearly the size of a bee-hive. On seeing the tail of a bird, I put my arm in and drew out what proved to be a very fine specimen of the Honey-Buzzard. I sent the bird for preservation; but after about ten years it crumbled to pieces. To prove the date, I enclose receipt for stuffing.-Thomas Gulliver, Crown Woodman."

On one occasion in September 1856 I witnessed a passage of great numbers of this species from Spain to Africa. Our vessel was becalmed off Europa Point, and from about noon till dusk the Honey-Buzzards kept passing over and on both sides of us in flocks of from half a dozen to eighty or more, at intervals of a few minutes, at no very great lieight above the water, although for the most part out of gunshot from our ship. Colonel Irby states that the vernal passage of this species to the northward, as observed by him at Gibraltar, generally occurs during the last days of April and first fortnight of May, and extends over some twenty days. 


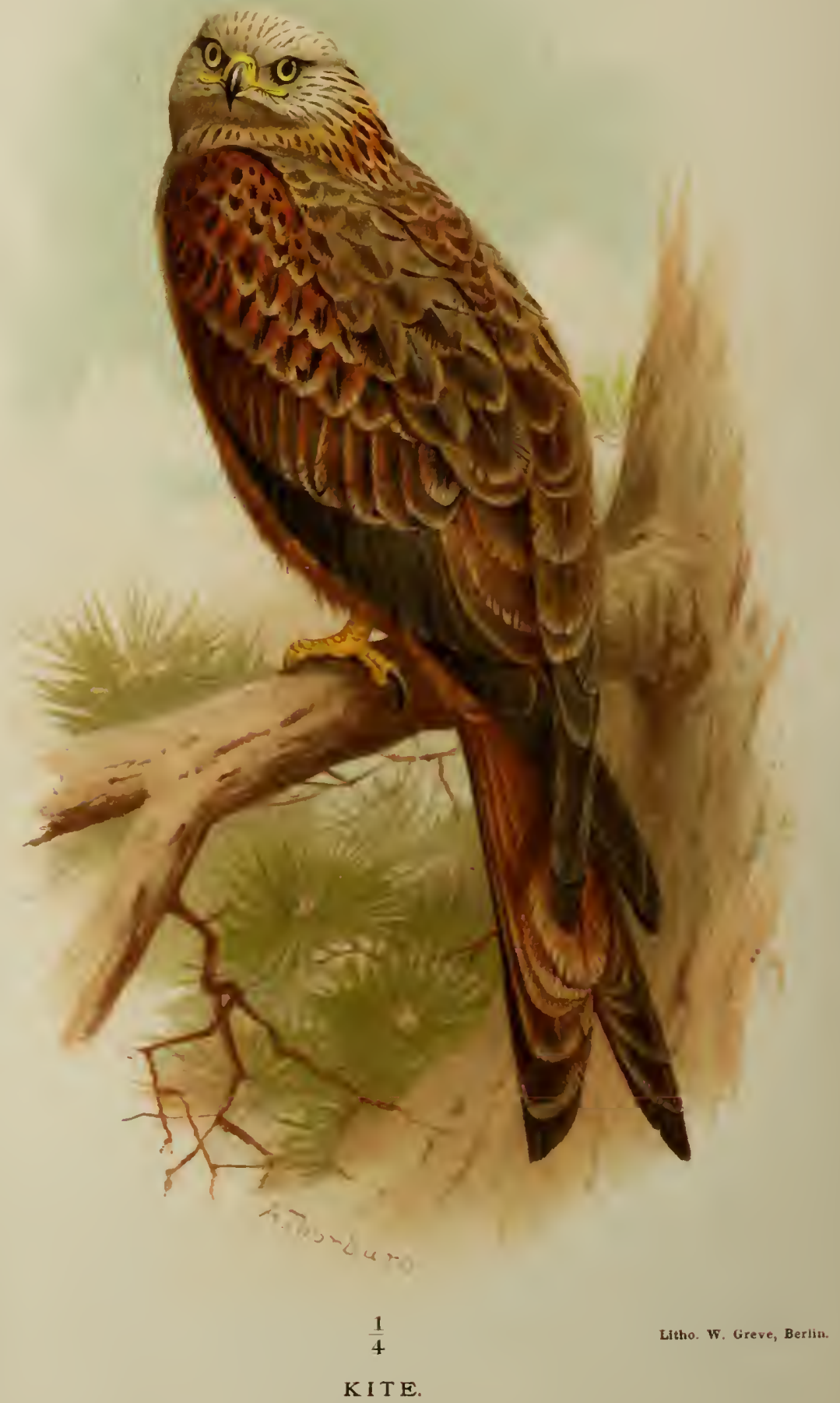

Milvus regalis (Pall) 


\section{KITE.}

MILVUS REGALIS (Pall.).

Accipiter regalis, Pall. Zoogr. Rosso-As. i. p. 356 (1811).

Falco milvus, Linn. S. N. i. p. 126 (1766) ; Naum. i. p. 333.

Milvus ictinus, Savigny, Syst. Ois. de l'Égypte, p. 28; Yarr. ed. 4, i. p. 92 ; Dresser, v. p. 643.

Milvus regalis, Macg. iii. p. 265.

Milvus vulgaris, Hewitson, i. p. 36 .

Milan royal, French; rothe Milan, Gabelweihe, Grerman; Milano real, Spanish.

This beautiful bird, which, within my recollection, was by no means uncommon about our home in Nortlamptonshire, and abundant in some of the great woodlands of Huntingdonshire, as in many other parts of England, is now very rare in Great Britain. Certain districts of South and North Wales are still ornamented by the occasional visits of the Kite, and I feel sure that all lovers of birds must have shared my disgust at a recent announcement in the 'Field' that no less than five of this species had been slaughtered within a small area of the Principality since the beginning of this year (1889). I believe that a few Kites still annually visit the Highlands of Scotland, and can only hope that the protection afforded in one praiseworthy instance that has 
come to my knowledge may be extended far and wide. I cannot believe, from my acquaintance with the habits of this bird, that it would ever be likely to inflict serious loss upon game-preservers, though, from its habit of hanging around villages, small chickens are occasionally taken by it. In many parts of the continent our bird is still common, especially so in Spain, in which country many Kites may often be seen soaring in wide circles over hill and plain, and their shrill plaintive cry is constantly to be heard. $\Lambda^{\top} 0$ refuse or garbage comes amiss to these birds, and they are certainly most efficient inspectors of nuisances. The nest of the Kite is usually built in a high tree with a strong foundation and walls of dead sticks, and a curious assortment of various "unconsidered trifles" as lining. Mr. John Hancock has informed me that a Kite's nest, taken many years ago in Northamptonshire, contained a bit of saddle-girth, a bit of red worsted binding, a harvester's glove, and many pieces of paper and linen, and I am acquainted with more than one instance of purses containing money having been found in nests of this bird. The eggs are usually three in number, white, with rust-coloured spots and streaks. 



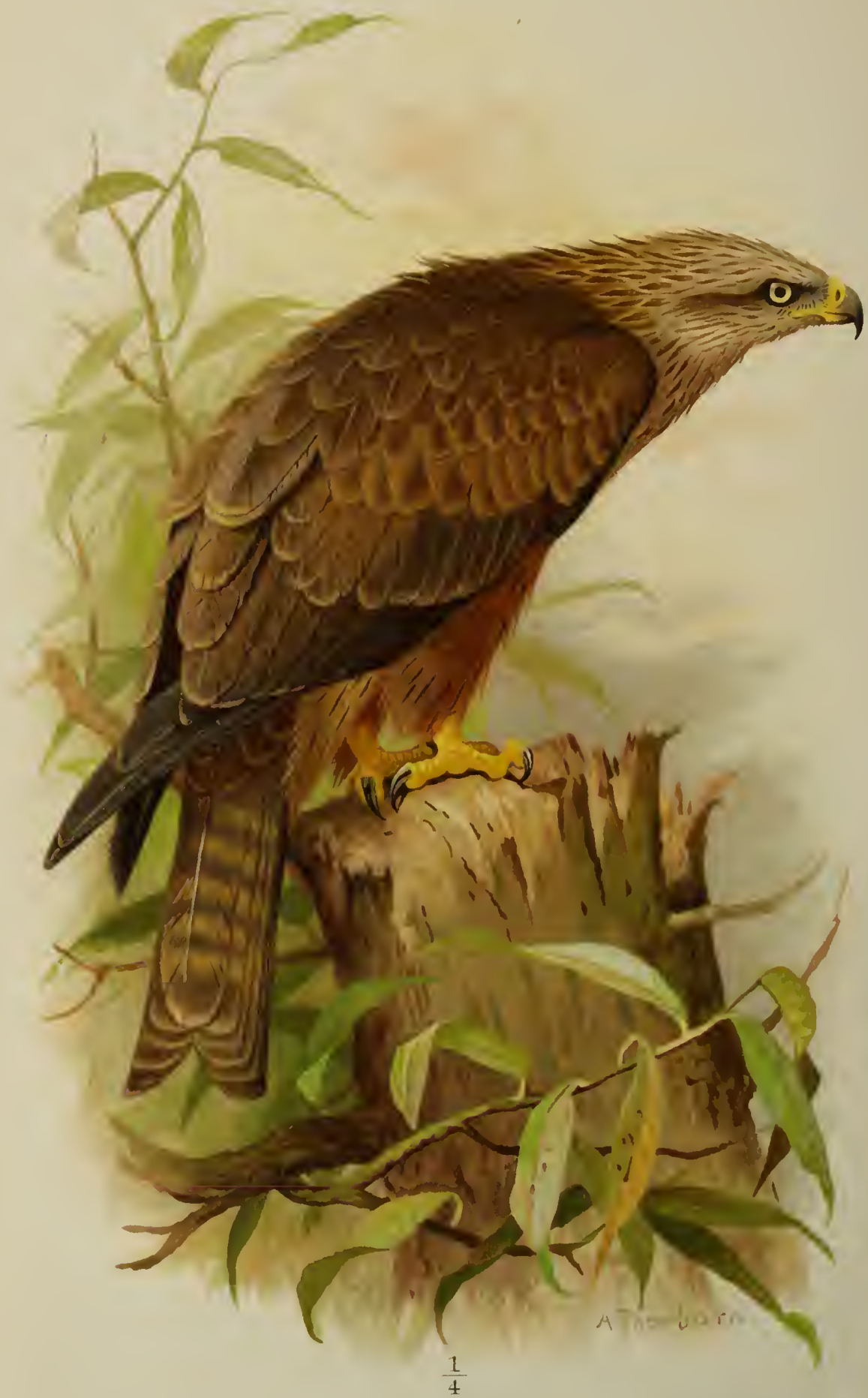

Litho. W. Greve, Berlin.

BLACK KITE.

Milvus migrans (Boddaert). 


\section{BLACK KITE.}

MILVUS MIGRANS (Boddaert).

Falco migrans, Boddaert, Table des Planches Enl. p. 28. no. 472 (1783).

Faleo ater, Naum. i. p. 340.

Milvus migrans, Yarr. ed. 4, i. p. 97 ; Dresser, v. p. 651.

Milan noir, French; Schwarzer Milan, German; Milano negro, Spanish.

I only use the ordinary English name for this species for want of a better, as the bird is certainly not "black," and to call it "migratory" would not distinguish it from other nembers of its family. 'The only recorded occurrence of this Kite in this country is that of a specimen taken in a trap at Alnwick, Northumberland, and brought in a fresh statc to the late Mr. John Hancock on May 11, 1866; this bird, an adult male, is now in the Museum of Newcastle-on-Tyne. 'I'his bird is a common summer visitor to the plains of Central Europe, Southern France, Spain, and North Africa ; in all these countries I have observed it, but my principal acquaintance with it was formed in Central and Southern Spain; in Andalucia it arrives early in March, and from that period till the cnd of September may be met with 
more or less abundantly in alnost all parts of the Spanish Peninsula. I have very seldom found the Black Kite in mountainous or even hilly districts, it seems to affect especially the woods on the marshy plains or the banks of large rivers. In general habits this bird much resembles the Common Kite, but, as far as my own experience goes, is more addicted to a diet of reptiles, fishes, and insects than that species. In Spain the present species generally nests in pine-trees, poplars, or willows, at a considerable height from the ground: several pairs are often to be found breeding in close vicinity. I never noticed such a variety of rubbish in the materials of the nests of the Black Kite as in those of the "Forky-tail," as the Common Kite was frequently called at the time when it really was "common" in this country; the eggs are white, with speckles and streaks of rusty brown. In Central Spain we generally met with large colonies of the so-called "Spanish" Sparrow (Passer salicicolus) nesting in the immediate neighbourhood of both species of Kite, and in more than one instance actually found nests of these Sparrows amongst the foundations of those of the Kites. 


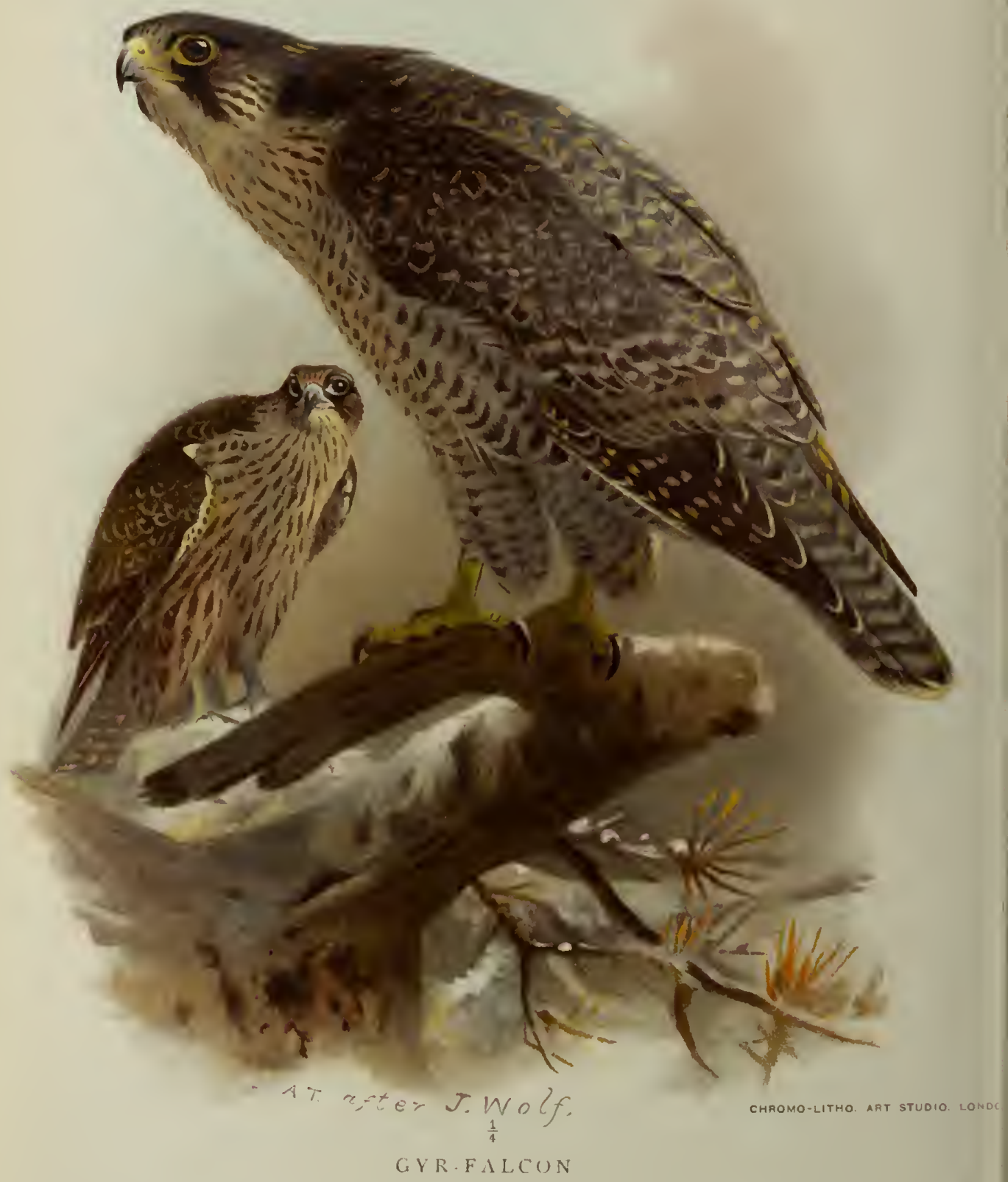

Falco gyrfalco, Limn. 


\title{
GIR-FALCON。
}

\author{
FALCO GYRFALCO, Linn.
}

F̣alco gyrfalco, Linn. S. N. i. p. 130 (1766) ; Naum. xiii. p. 22 ; Yarr. ed. 4, i. pp. 36, 46; Dresser, vi. p. 15.

Gerfaut de Norvége, French ; Gierfalke, German; Gerifúlte, Spanish.

I can only discover two records of the occurrence of this Scandinavian Falcon in our country, viz. one killed in Sussex in 1845, now in the collection of Mr. W. Borrcr, who tells us in his 'Birds of Sussex' (1891) that his specimen, which he at first considered as an Iceland Falcon, was identified as an adult of the present species by the late Mr. John Henry Gurney. Mr. Borrer, in the work to which I have just referred, gives an excellent figure of this Falcon, which proves, were any proof needed, the correctness of Mr. Gurney's identification. The other occurrence to which I have alluded is recorded by Mr. H. Seebolım, 'British Birds,' vol. i. p. 19 (1883), who states that an immature cxample of the "Norwegian form of Jer-Falcon" was shot at Orford, in Suffolk, in the act of devouring a hen, on October 14th, 1867, and was, at the timc of Mr. Seebohm's writing, in the possession of Mr. Ed. Hunt, of Pimlico, the brother of its destroyer.

I will not go into the much disputed question of specific distinction betwcen the Gyr and Iccland Falcons further than by saying that althcugh the inmaturc 
birds are very closely alike in plumage, there is a constant difference of " nnake" and character between them that would, I think, at once strike the eye of a falconer; about the adult birds there can hardly be any mistake.

The Gyr-Falcon is from all accounts resident in many parts of Scandinavia, where it nests in cliffs and high trees, and preys principally upon Ptarmigan and Waterfowl. It must bc locally abundant, as John Wolley found upwards of twenty nests in West Finmark; and the well-known falconer John Barr (who was sent to Norway by Captain Dugmore and me some years ago for the express purpose) succeeded in catching sixteen fully fledged young birds of the year during a few weeks' stay in that country. 'This Falcon was held in high repute by ancient falconers; but my small experience with it goes to prove that it evidently requires a large expanse of open country to enable it to put forth its best qualitics, and that it is practically useless amongst enclosures. The flight of the fow of this species that I have seen on wing under the disadvantages just mentioned, though strong and vigorous, could not compare in speed with that of the Greenland Falcon in the same circumstance; but I have never seen the Gyr-Falcon in a wild state. One of these birds was taken at Vnlkenswaard, in South Brabant, many years ago to my certain knowledge, and is not, I think, the only one that has becn caught at the Hawkhuts in that district; but its range of migration appears to be far more limited than those of the Iceland and Greenland Falcons. 



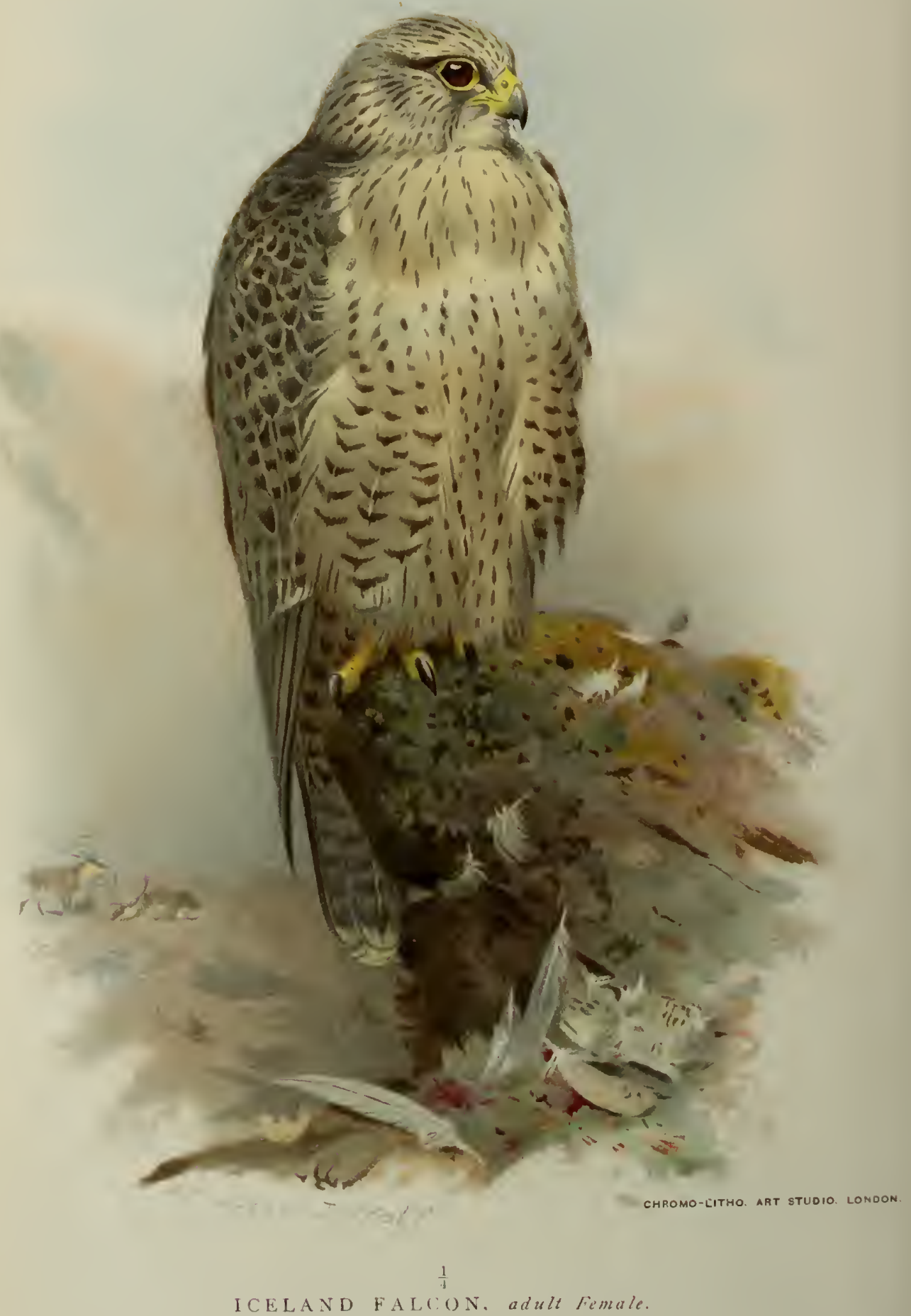

Falco islandus, F. F: Gimelun 


\section{ICELAND FALCON.}

FALCO ISLANDUS, J.F. Gmelin.

Falco islandus, Gmelin, Syst. Nat. i. p. 271 (1788); Naum. xiii. p. 22; Yarr. ed. 4, i. p. 46 ; Dresser, vi. p. 25.

Falco gyrfalco, Macg. iii. p. 284.

Falco islandicus, Hewitson, i. p. 22.

Gerfault Islandais, French; Isländischer Fulke, German.

This Falcon, although it breeds in Iceland, and is by no means uncommon there, is, from all accounts, a less frequent visitor to our Islands than the "Greenlander;" but it is more than probable that there may be some confusion of these two species in the published records of occurrences, and the fact that there are two wellmarked and distinct races of the present species, apart from the Gyr-Falcon of Scandinavia, F. gyrfalco, has no doubt tended to complicate correct identification. From having kept some of all the three northern Falcons in captivity, I am convinced that the Icelander, and the true Gyr-Falcon to which I have just alluded, are suffciently distinct to be entitled to rank as separate species, although $I$ am quite willing to admit that the immature birds are so much alike that no falconer, lowevcr experienced, could pronounce a decisive opinion upon their 
specific identity. As I have never visited Iceland, I can say nothing from personal experience of the habits of this Falcon in a wild state, but I have heard much about them from various persons who have observed them closely in their home, especially from the late Mr. Proctor, of Durham, who, if I recollect rightly, paid several visits to Iceland for bird-collecting purposes. From these accounts it seems that the "Icelander" closely resembles the Peregrine in its breeding-habits and general manner of life. The nest is placed on the ledges of cliffs and is more bulky than an average Peregrine's nursery, being composed of twigs of willow and dead sticks, and lined with wool. Sea-fowl and Waders form the principal diet of this Falcon, but a friend who visited Iceland many years ago, and presented me with a very fine skin of the present species, told me that the Ptarmigan also suffer severely from the attentions of our bird, who picks tlicm up from the ground more often than she takes them on wing. I do not gather from my informant that the Falcon is by any means specially addicted to the coasts for breeding or other purposes, but this inference is probably due to the fact that my information is derived from summer visitors to Iceland. From a falconer's point of view, I have had but very slight acquaintance with the Iceland Falcon, and am not inclined to rate her highly, but it must be borne in mind that all the birds of this species trained in this country havc necessarily had the great disadvantage of a sea-passage, and in many instances have arrived so much damaged in plumage that they could not be put on wing till after the first moult; 


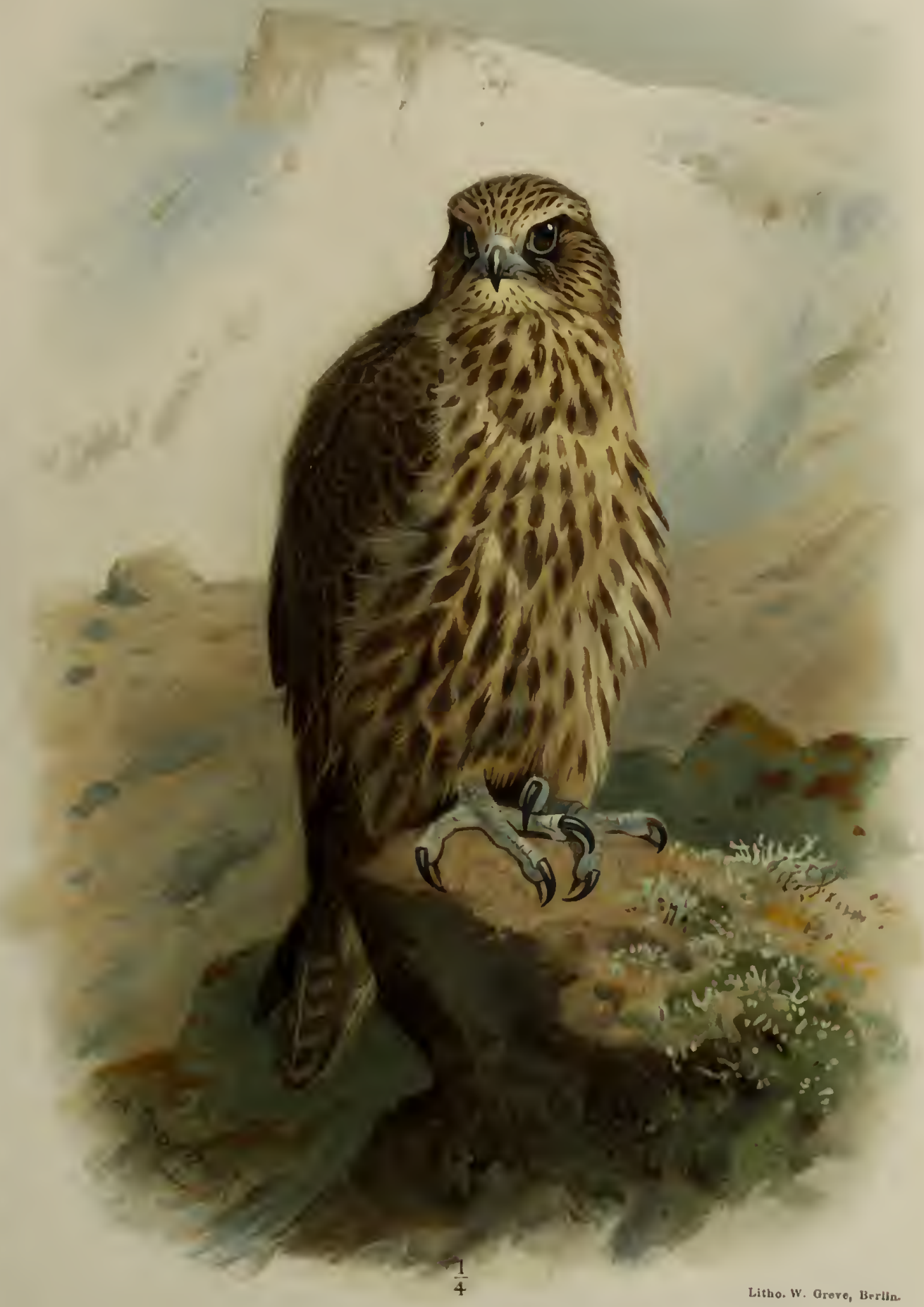

ICELAND FALCON, Female immalure.

Falco islandus, J. $\boldsymbol{l}$ : Gimelin. 

all falconers know how much Hawks suffer from a lengthened period of inactivity. Our ancestors seem, howcver, to have esteemed the "Icelanders" highly; there are traditions of their being trained to take the Kite, and in more recent days a few of these Falcons were flown at Herons with success in the Netherlands.

The late Mr. E. Clough Newcome, certainly the first amateur falconer of his day, owned several of these Falcons, and spoke highly of the performance of one or two of them, but on the whole did not care very much about thcm, and infinitely preferred the "passage" Peregrine for practical purposes. The late Maharajah Duleep Singh flcw "Icelanders" with some success at Hares in Suffolk, but I could not get an "Icelander" of mine to look at a live rabbit, and, indeed, I hold that this sort of work is altogether beneath the hereditary dignity of a true Falcon. In my experience I have found the "Icelander" difficult to keep in health for any length of time, even when the bird is constantly exerciscd; the feet especially generally go wrong sooner or later, and are exceedingly difficult to treat successfully. In disposition this Falcon seems to be tameable crough, but by no means remarkable for docility, of a somewhat sluggish temperament, and it is by no means so hardy as might be expected from the climatic conditions of the country of its origin. 



\title{
GREENLAND FALCON.
}

\author{
FALCO CANDICANS, J. F. Gmelin.
}

Falco candicans, Gmelin, Syst. Nat. i. p. 275 (1788); Naum.

i. p. 269 , xiii. p. 16 ; Yarr. ed. 4 , i. p. 36 ; Dresser, vi. p. 21.

Falco gyrfalco, Macg. iii. p. 284.

Jagd-Falke, Edel-Falke, Grïnländischer-Falke, German.

This beautiful Falcon is a scarce and irregular winter visitor to the United Kingdom. From the fact that two, or perhaps three, species, of which the present bird is one, were formerly lumped together under the name of "Jer" (properly "Gyr") Falcons, a good deal of confusion has arisen as to the identification in several instances of the occurrence of the northern Falcons in our Islands; but this species is to be distinguished at all ages from the Iceland and Norway Falcons by the fact (first made known by Mr. Joln Hancock) that the ground-colour of its plumage is always white, whereas the two birds last named have a generally darker plumage, marked with white or light grey; to the eye of a falconer there is a peculiar "make" and character about the Greenland Falcon that arc quitc sufficient to 


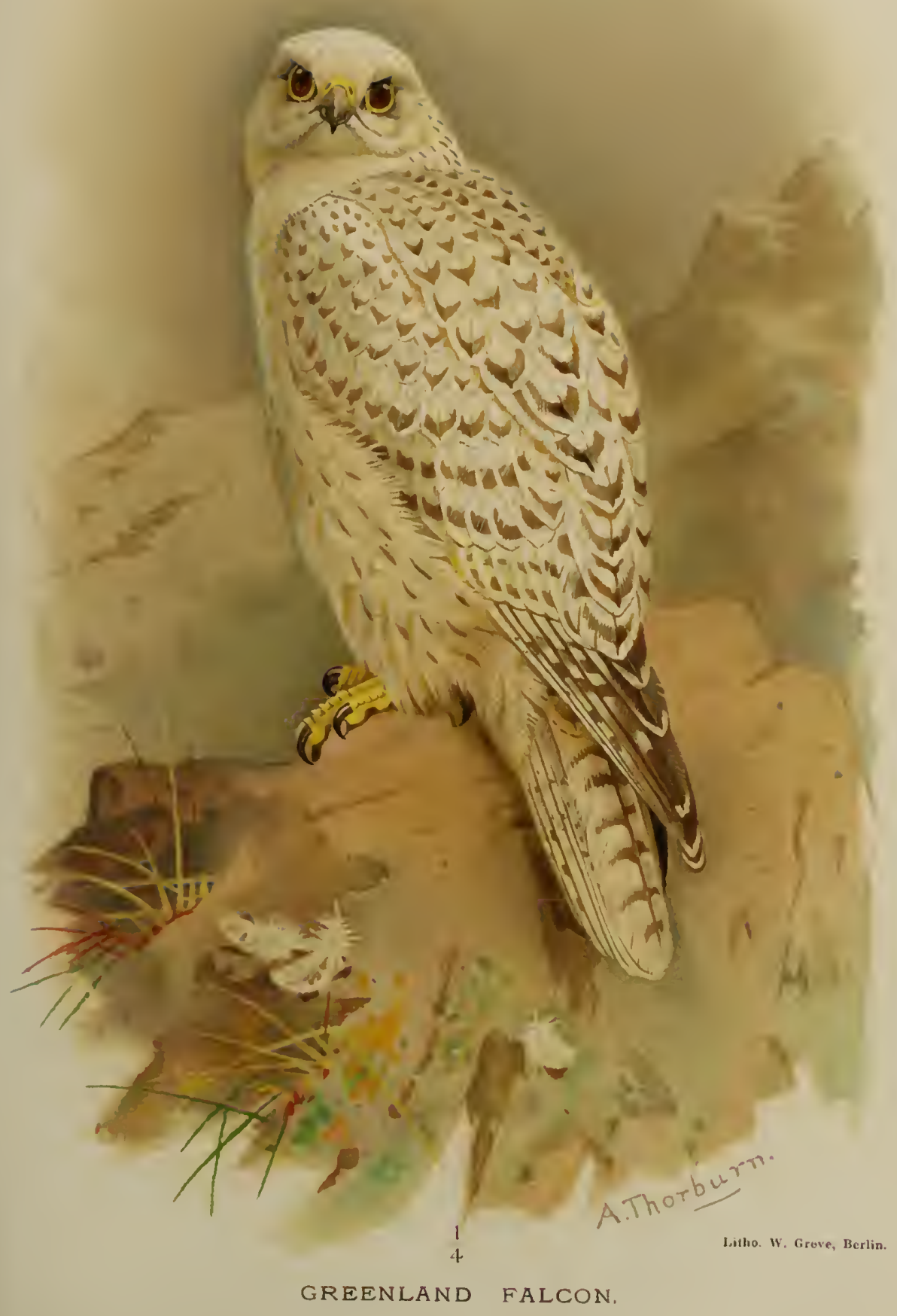

Falco canclicans, J. F. Fimlin. 

enable him to identify her, even if she were jet-black. An old gamekeeper, native of Rannoch, Perthshire, and formerly in my employment in Inverness-shire, assured me that the "White Falcons" very frequently visited Loch Raunoch and Loch Tummel during the wintcr months, and that he had at various times shot and trapped four or five, and seen many others; one of these victims I discovered in the shop of Mr. Paton, the well-known gunmaker at Pertl ; it was a young male, killed near Foss, on Loch Tummel, in the early spring of 1862. I had the pleasure of presenting this specimen to the late E. Clough Newcome, of Feltwell, Brandon, Norfolk, an old and valued friend, and in his day without a rival in this country as a practical falconer.

John Campbell, the gamekeeper to whom I have above alluded, told me that these "White Falcons" seemed to prefer Rooks to any other quarry, but that they made the wild fowl very "uneasy"; he never saw one in pursuit of a Red Grouse, but once saw one make an ineffectual stoop at an old Blackcock; on the whole, from his professional point of view, he did not look upon the Greenlander as such "a bad vermin"! as the "Hunting Hawk," i. e. Peregrine.

My experience of this bird in captivity is to the effect that it is extremely docile, and a very fine and powerful flyer and stooper, but what we call in falconry a poor "footer," that is, it is not able, or more probably not disposed, to bind to and grasp its quarry firnly; it is also by no means hardy of constitution, and is difficult to kccp in good condition for field 
purposes. This bird is known to breed in Greenland and the arctic regions of continental North America; it has been met with in Northern Asia and Spitzbergen, and seems to be a more or less regular autumnal visitor to Iceland.

I must refer my readers to the fourth edition of Yarrell's 'British Birds' for details relating to the ligh value formerly set upon the Greenlanders by falconers, who are said to have trained them successfully at Cranes, Herons, Wild Geese, and ground-game; there is also a tradition that they took Kites, but I do not think that in this case the species of the captor is clearly defined.

The Plate that accompanies this article was taken from a very fine adult living female at Lilford, one of the tamest Falcons that I ever knew; she has, I grieve to say, departed this life since her portrait was taken. 



\section{PEREGRINE FALCON.}

FALCO PEREGRINUS, Tunstall.

Falco peregrinus, Tunstall, Ornith. Brit. p. 1 (1771); Naum. i. p. 285 ; Macg. iii. p. 294; Hewitson, i. p. 24; Yarr. ed. 4 , i. p. 53 ; Dresser, ri. p. 31.

Faucon commun, Faucon pèlerin, French; Wanderfalke, German; Halcón, Halcón real, Spanish.

This most noble of birds, although ruthlessly persecuted by game-preservers in many districts, still breeds annually on various parts of the coasts of the three kingdoms and their adjacent islands, as well as in some inland localities, but in most of our English counties is best known as an autumnal visitor, generally following the annual sonthward migration of Wild-fowl and Wood-Pigeons, and frequently, if not molested, remaining during the winter and late into the spring in places that afford a sufficiency of prey and facilities for the capture thereof.

I suppose that it would be a hopeless task to attempt to explain to any but those few who love sport in its higher sense for its own sake, the feeling that falconers entertain for the Peregrine, lallowed to them as she is by tradition of ages, and their most "generous" and 


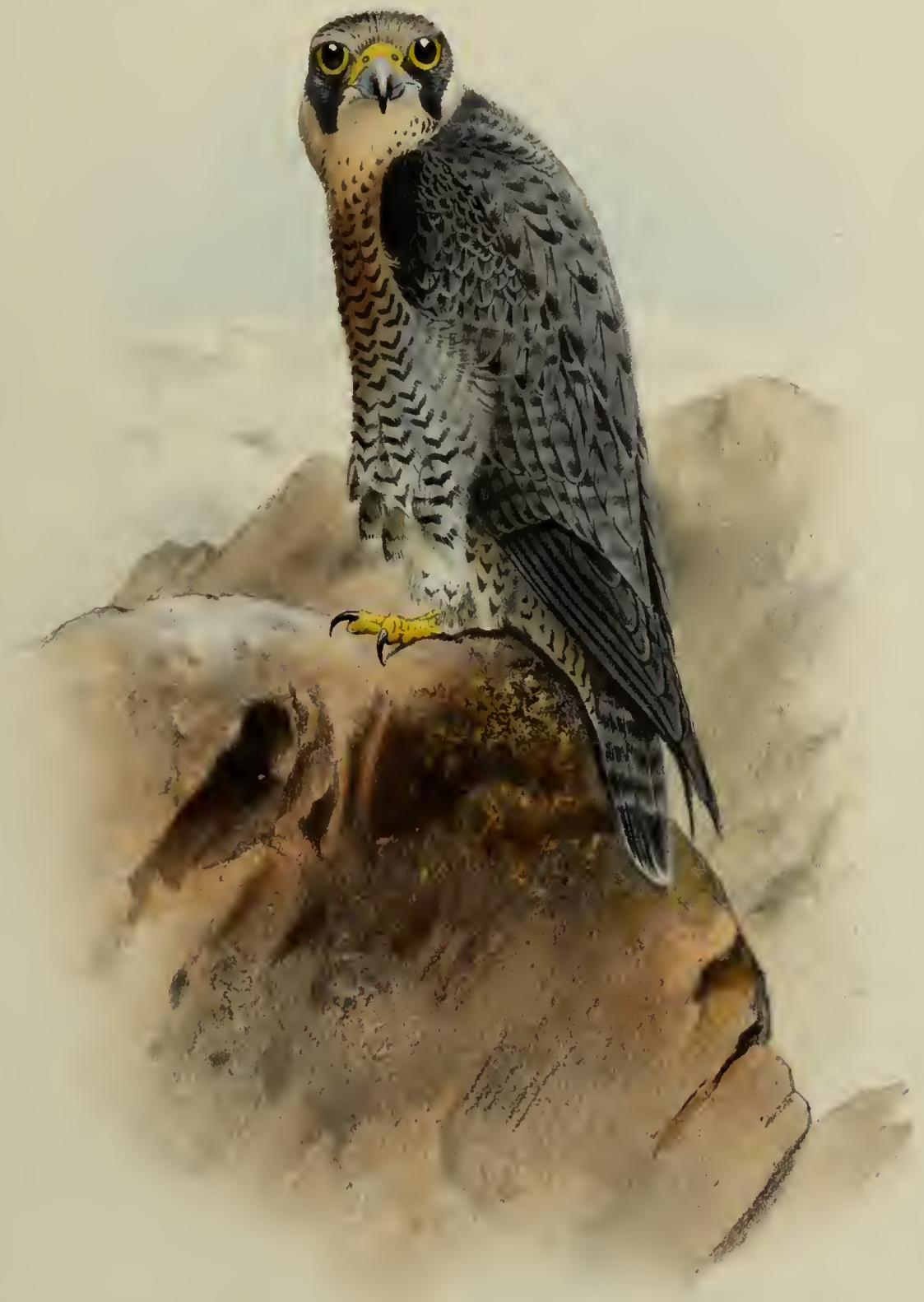





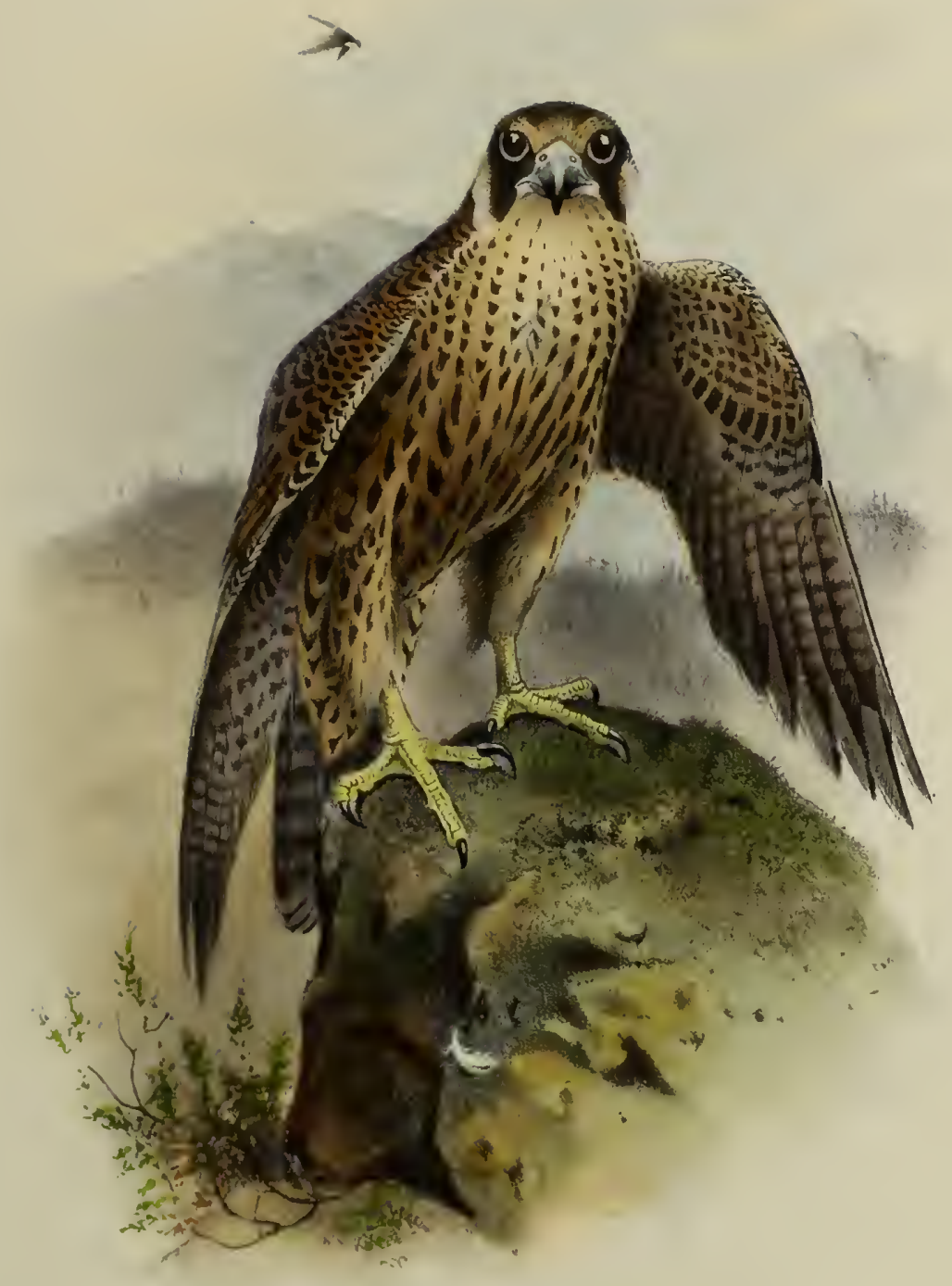

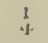

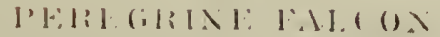

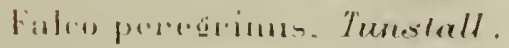

in MLE it FIHST PEAP 

efficient ally in the most interesting of the many branches of field-sports. I do not pretend to claim for my favourite bird the unquestioning attachment to its master or the sagacity of the dog, or to compare its merits and value with those of the horse; but I do most strongly urge its claims to protection as affording opportunities for most wholesome exercise of mental and physical powers in training, flying, and following. Some of my enthusiastic fellow-falconers have gone so far as to deny altogether that our Falcon is prejudicial to game; but this is an over-statement of the case which in my opinion is detrimental to our cause; the Peregrine can and does take Grouse and Partridges when she gets a fair chance and is hungry, but it must be remembered that as a rule she captures her "quarry" in the air, and that our common game-birds just mentioned are of terrestrial habits and certainly by no means willing to take wing when a Falcon is in sight, but do their utnost to squat close and conceal themselves, so that they are by no means the habitual or even (in my opinion) a particularly favourite prey of the Peregrine. From my own experience in this country and in other parts of Europe I am convinced that Pigeons, the smaller species of the Duck family, especially Teal, and wading-birds of all kinds are the most usual and most natural food of the Falcon, and I do not think that the most ardent lover of the gun should grudge her a due share of these. Personally I would rather see one fine stoop of a wild or trained Falcon than shoot and kill any bird that ever flew; but, of course, I cannot expect many to agree with me on this 
subject, and have written the above rhapsody simply as an appeal to the few who can sympathize in the chief delight of a still smaller portion of the community.

The nest of the Peregrine is generally situated on a ledge or in a cavity of sea-cliffs or inland crags, and has been occasionally found on elevated buildings. The eggs are generally three, not uncommonly four, in number.

In treating of this bird as above, from a falconer's point of view, I have advisedly used the feminine article, as from that standpoint the word Falcon is applied exclusively to the female bird, which is very much larger and more powerful than the male, and consequently held in ligher estimation for sporting-purposes; the latter, in the language of falconry, is known as Tiercel. The progress of cultivation and consequent enclosure have virtually circumscribed the available area for falconry in our country to a very great extent, an open treeless district being the first essential to its successful practice; but in spite of every difficulty the noble art is still kept up in our islands, and by many of the officers of our army in India, where it can be carried out in the most favourable circumstances, with results quite unattainable at home.

The Peregrine ranges over the whole of Europe and Asia, and is represented by very closely allied forns in Africa, Australia, and the New World. 



\section{HOBBY.}

FALCO SUBBUTEO, Linn.

Falco Subbuteo, Linn. S. N. i. p. 127; Naum. i. p. 296 ; Macg. iii. p. 309 ; Hewitson, i. p. 26 ; Yarr. ed. 4, i. p. 65 ; Dresser, vi. p. 69.

Le Hobereau, French ; Baum-Falke, Lerchen-Falke, German; Alcotan, Spanish.

One of the latest summer visitors to England, in which country it is never abundant.

Breeds irregularly in several of the midland, eastern, and southern counties.

It rarely visits Scotland or Ireland.

The Plates represent an adult male in full summer plumage, and a bird in that of the first year. 


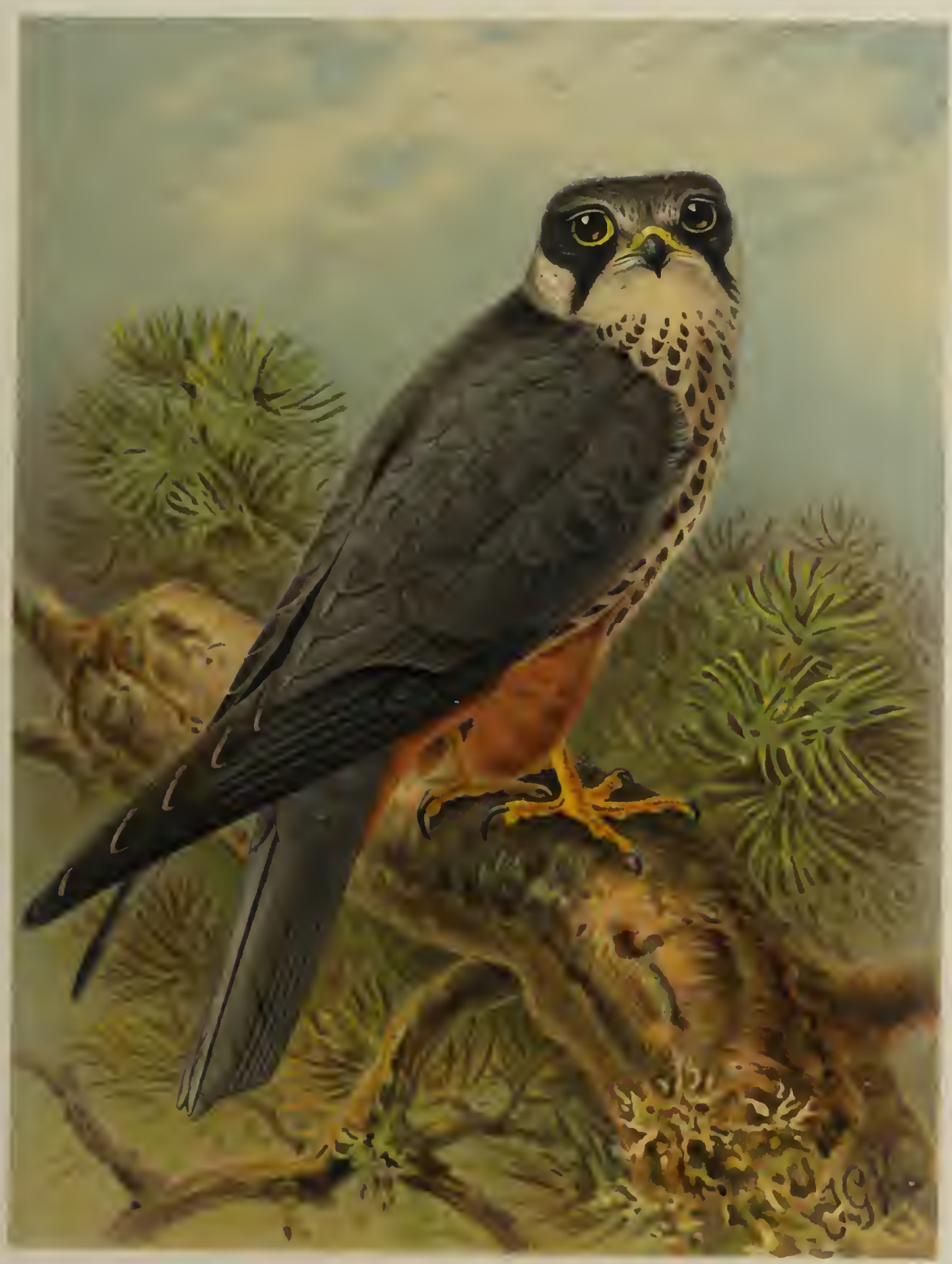

1.itho. W. Greve, Berlin-Loudon

H OB BY, achele).

I'alen subbuteo, Linn.

$\frac{1}{2}$. 



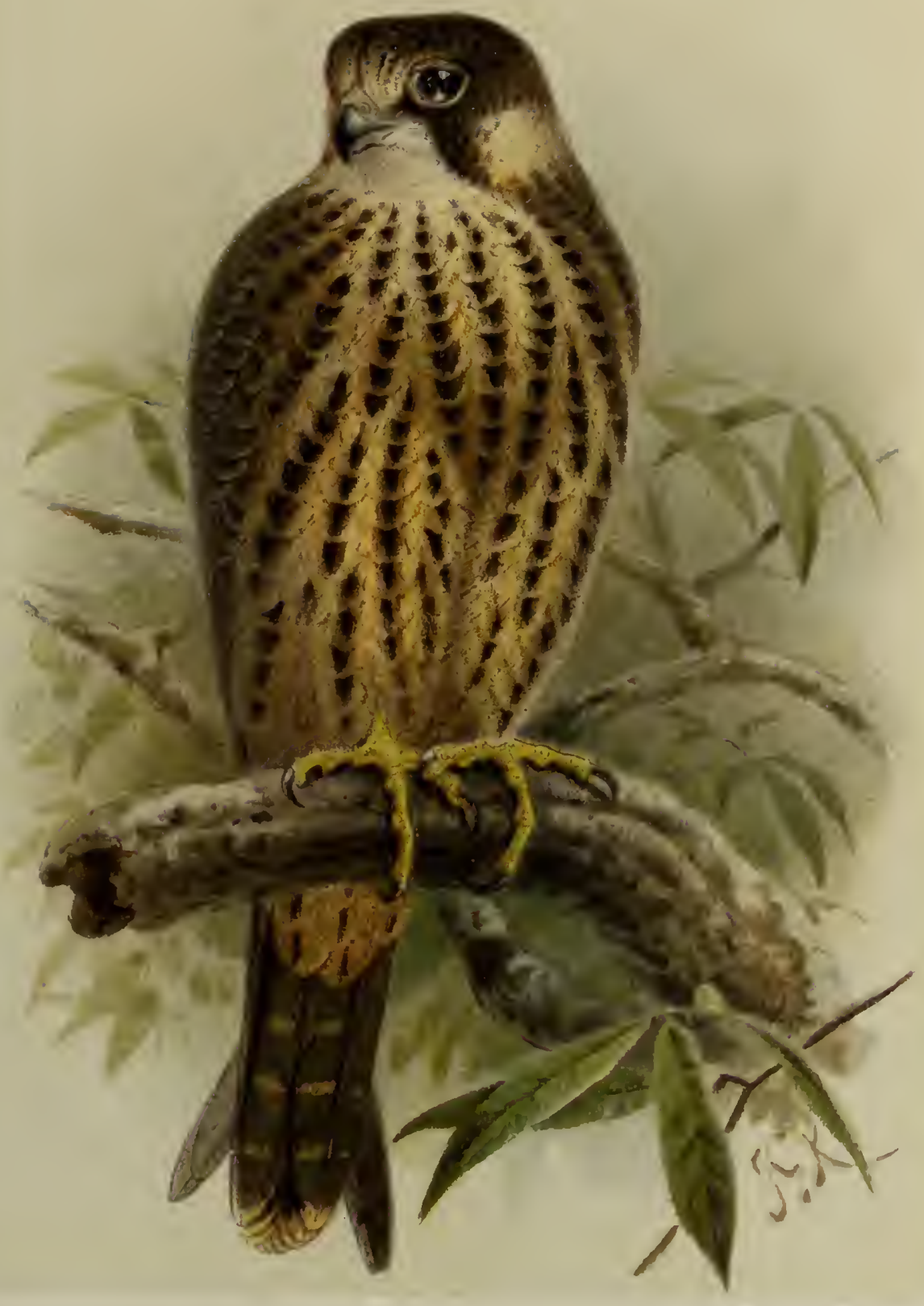

$\mathrm{H} O \mathrm{~B} \mathrm{~B}$ Y (immalnre)

Falen subbuteo, Linn 

. 


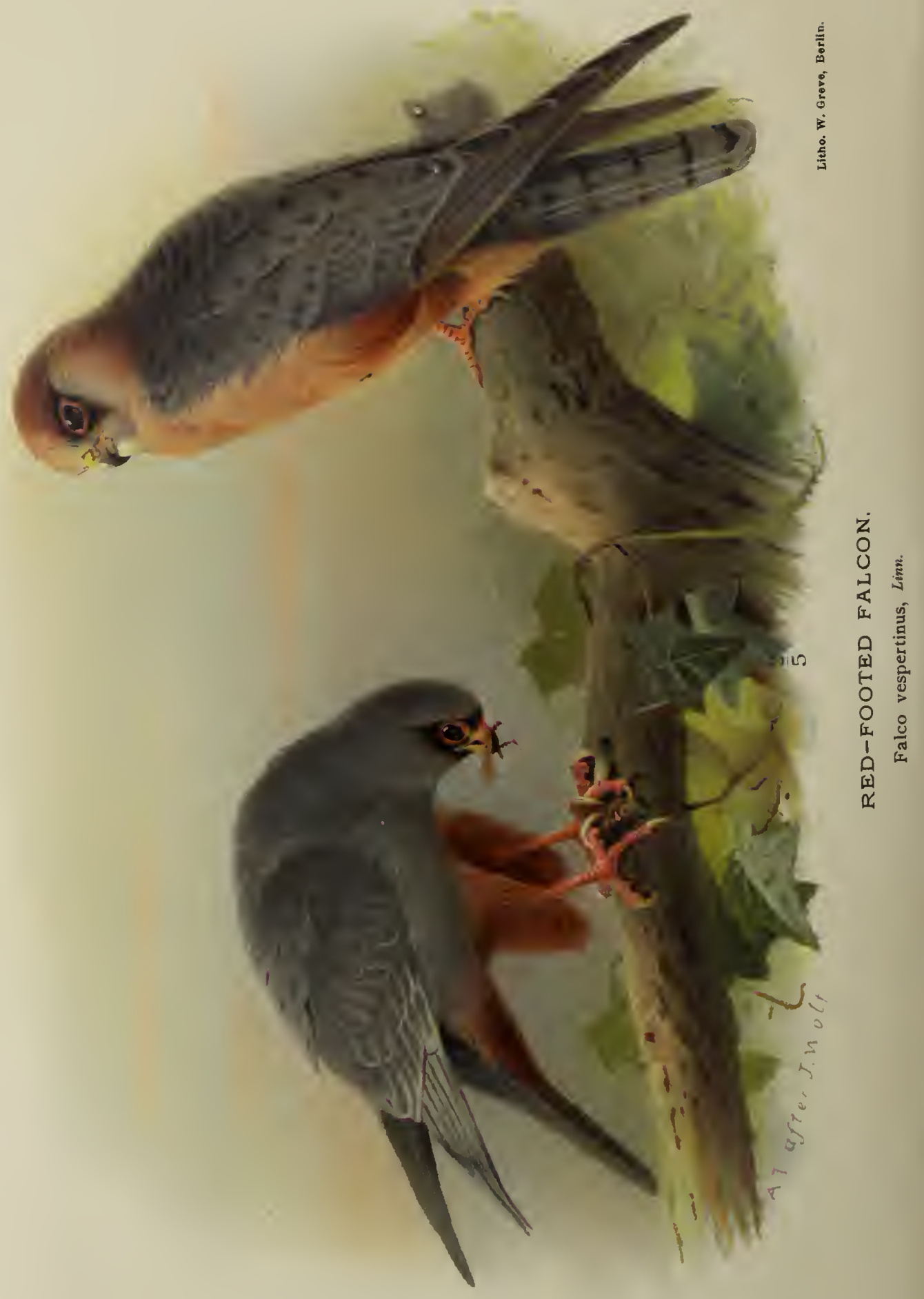




\section{RED-F0OTED FALCON.}

FALCO VESPERTINUS, Linn.

Falco vespertinus, Linn. S. N. i. p. 129 (1766); Macg. iii. p. 313 ; Hewitson, i. p. 28; Yarr. ed. 4, i. p. 69; Dresser, vi. p. 93.

Falco rufipes, Naum. i. p. 311.

Faucon Kobez, French; Rothfuss-Falke, German.

This very beautiful little Falcon is an irregular and uncommon visitor to the British Islands, in all probability for the good reason that these Islands lie far to the westward of its breeding-haunts and its accustomed routes of migration. To the Ionian Islands, where I first made the acquaintance of this species, it is a regular and, in some years, a very abundant vernal visitor; but, so so far as I was able to ascertain, in Corfu it only remains for a few days. I once fell in with a small flock of Red-footed Falcons on the shores of the Lake of Geneva in May 1851; I saw one on wing in Andalucia in the early summer of 1884, and found it in considerable numbers on one occasion only in Cyprus, near Limasol, on May 6th, 1875.

'This bird is eminently gregarious in labits, and in 
this respect, as in many others, closely resembles the Kestrels, especially the Lesser (Falco cencliris). It is, however, more crepuscular than the Common Kestrel, and, in my experience, is not very often to be seen on wing lunting for food till late in the afternoon; and it certainly frequently carries on its hunting long after the sun has set. During the stay of these Falcons in Corfu they seemed to spend the hot liours of the day perched in small clusters on the tall cypresses and few poplars that diversify the lovely scenery of the island; as the day waned these birds might be observed hovering and circling in every direction at a moderate height over the ficlds and olive-groves, showing a decided predilection for the neighbourhood of streams or ponds of freshwater. 'They had no fear whatever of human beings, and frequently flew past or hovered within half a gun-shot of us as we sat or stood perfectly unconcealed.

I believe that this Falcon takes its prey principally on wing, but also not infrequently from the ground, upon which it runs with remarkable case and speed. The stomach of a specimen killed in Corfu contained portions of the remains of large moths, whilst the crop of the only one that I cared to shoot for identification in Cyprus was crammed with small dung-beetles.

Of the breeding-habits of this Falcon I know nothing from pcrsonal observation. For a most interesting account of the habits of this bird in Southern Russia I will refer my readers to a translation given at length by my friend Mr. H. E. Dresser in lis great work, the 'Birds of Europe,' rol. 6. The Red-footed Falcon 
breeds in small socicties in Hungary and other parts of South-eastern Europe; it generally occupies the abandoned nests of Crows or Magpies, and lays from four to six eggrs in May. With regard to the gregarious breeding-habits of this species I well remember to lave heard a story many years ago from the late E. Clough Newcome to the effect that some Rooks being required alive for the training of Percgrine Falcons at Vienna, an emissary was despatched thence to a reported "rookery" at some distancc down the Danube, and that on his arrival at the indicated locality he found that the Rooks' nests were entirely deserted by their builders, and most of them occupied by Rcd-footed Falcons.

The cry of this Falcon closely resembles those of the Hobby and the Lesser Kestrel, but is quite distinguishable from either by any one conversant with the smaller Falconida.

In my experience the present species very seldom comes alive into the hands of bird-dealers in this country, and is difficult to keep in captivity through the cold months, although I have not a doubt that during the summer it would thrive at "hack," i.e. at liberty, if taken from the nest, and "reclaimed," or broken to the fist, before it could fly. I consider the name "Orange-legged Hobby," that lias frequently becn applied by English writers to this Falcon, as quite a misnomer, and I look upon it in almost every respect as bcing cssentially of the Kestrcl family. 



\section{MERLIN.}

FALCO AESALON, Tunstall.

Falco æsalon, Tunstall, Ornith. Brit. p. 1 (1771) ; Naum. i. p. 303; Macg. iii. p. 317; Hewitson, i. p. 30; Yarr. ed. 4, i. p. 74; Dresser, vi. p. 83.

Faucon Emérillon, French; Zwerg-Falke, German ; Esmerejon, Spanish.

This beautiful little Falcon breeds on moorlands throughout the British Isles, and several instances of its nesting in trees in parts of our country where no moors exist are on record; but as a rule in the cultivated and woodland districts of Central and Southern England it is best known as a bird of double passage, closely attending the migratory hordes of Finches and Larks on their autumnal migration, and reappearing casually in early spring. On many parts of our coasts the Merlin remains throughout the winter months, and plays havoc amongst the smaller Waders and other shore-frequenting birds.

The nest of this bird is generally situated on a tussock on the open moor, the bank of a moorland burn or "scaur," and occasionally in rocks ; it consists 


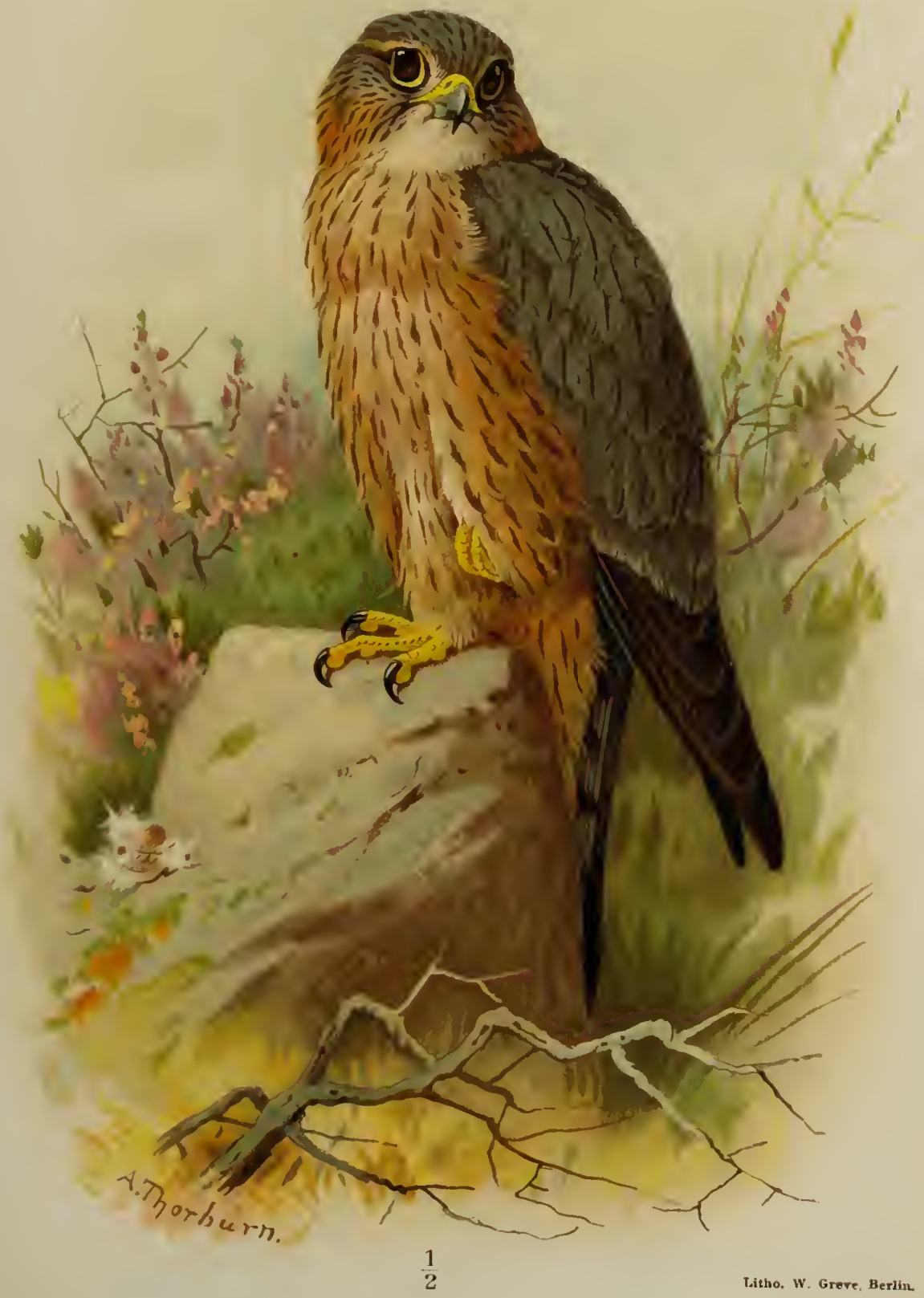

MERLIN, adult male.

Falco asalon, Tunstall. 



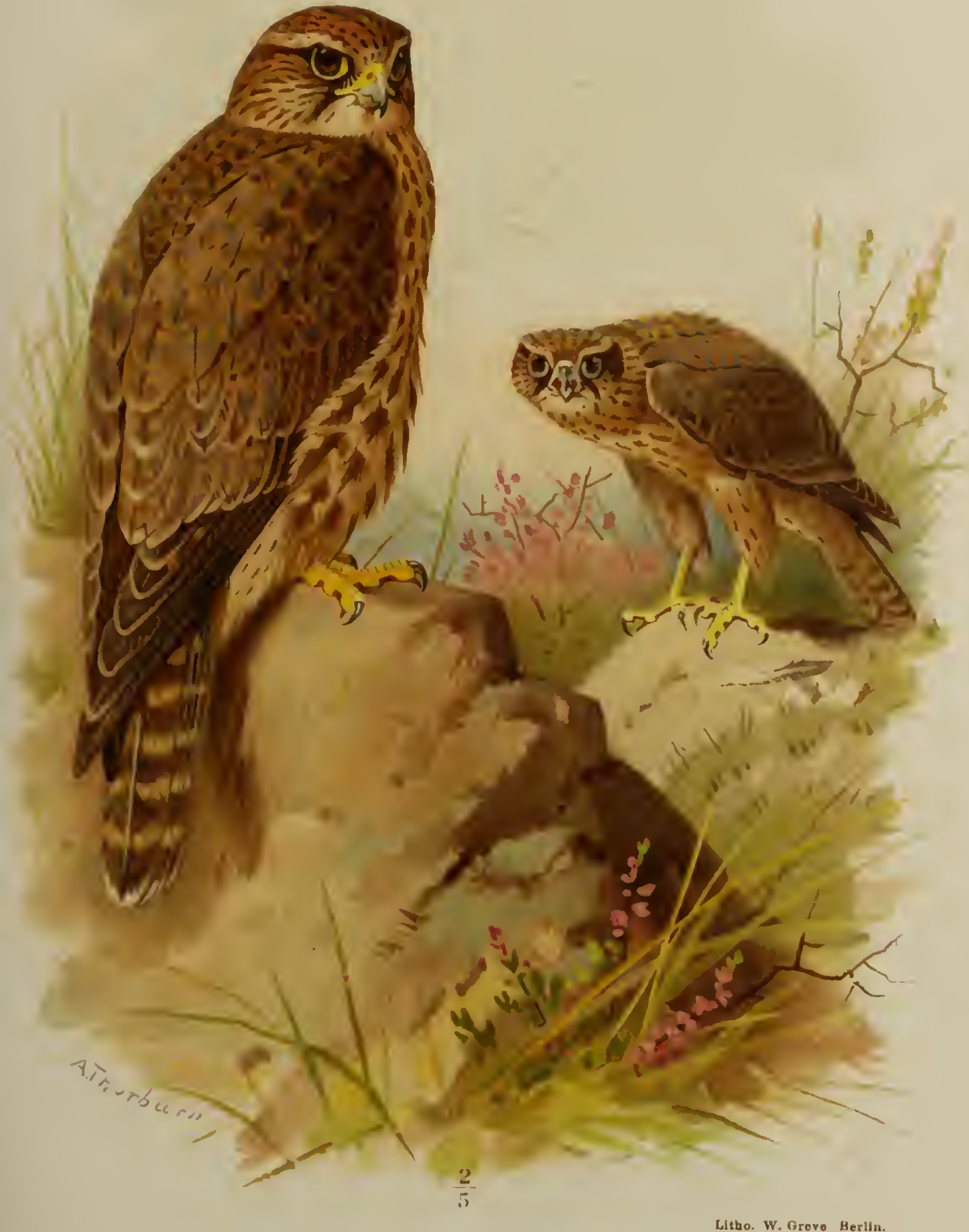

MERLIN, alult female \& immature male.

Falco xsalon, Tunstall. 

of a few twigs loosely laid together. The eggs, seldom more than four in number, do not vary nearly so much inter se as those of the Kestrel, but are generally more uniformly coloured, smaller, and not so rounded as those of that well-known bird. The Merlin is, for its size, a very powerful bird, and a beautiful flyer, very persistent in pursuit. I have seen but very little of its performances as a trained bird; but it has been, and still is occasionally, used to take Larks, Blackbirds, and Thrushes; and I have seen a trained female take a House-Pigeon after a long and difficult flight. When a Merlin's nest is approached the old birds show considerable courage in flying at human beings, dogs, or large predatory birds; but my experience does not lead me to credit them with the pluck and dash that is generally attributed to them. Inquisitiveness seems to be a prominent trait in this species, for I have repeatedly seen wild Merlins come to observe the proceedings of trained Peregrines on the wing, and more than once noticed one hovering over hooded Hawks on their " cadge." The Merlin seldom flies at any great height, except, of course, when in pursuit of any soaring quarry, or bound on a lengthy journey. In our district of Northamptonshire, where this species is by no means rare on passage, we generally notice it flying low along the course of our river or tributary brooks, or along the fence-sides, in search or pursuit of small birds. An old Wagtail or Pipit cuts out a Merlin's work for her; and I have often witnessed beautiful and prolonged fliglits at these hirds, which generally, in the winter season, terminated in favour of 
the intended victim. On the high moorlands, however, I believe that young Meadow-Pipits form the principal diet of the Merlin during the summer months. Many gamekeepers consider our bird as very destructive amongst young Grouse; but although I am well aware that the Merlin will take its prey on the ground more readily perhaps than any European Falcon except the Kestrel, I do not think that any serious amount of harm can be caused by it amongst game-birds, as, whilst they are small enough to be liable to attack from the Merlin, they are jealously tended and protected by their parents. In captivity the Merlin is remarkably docile, but requires great care and skilful management to keep it for any length of time in good flying conclition. 


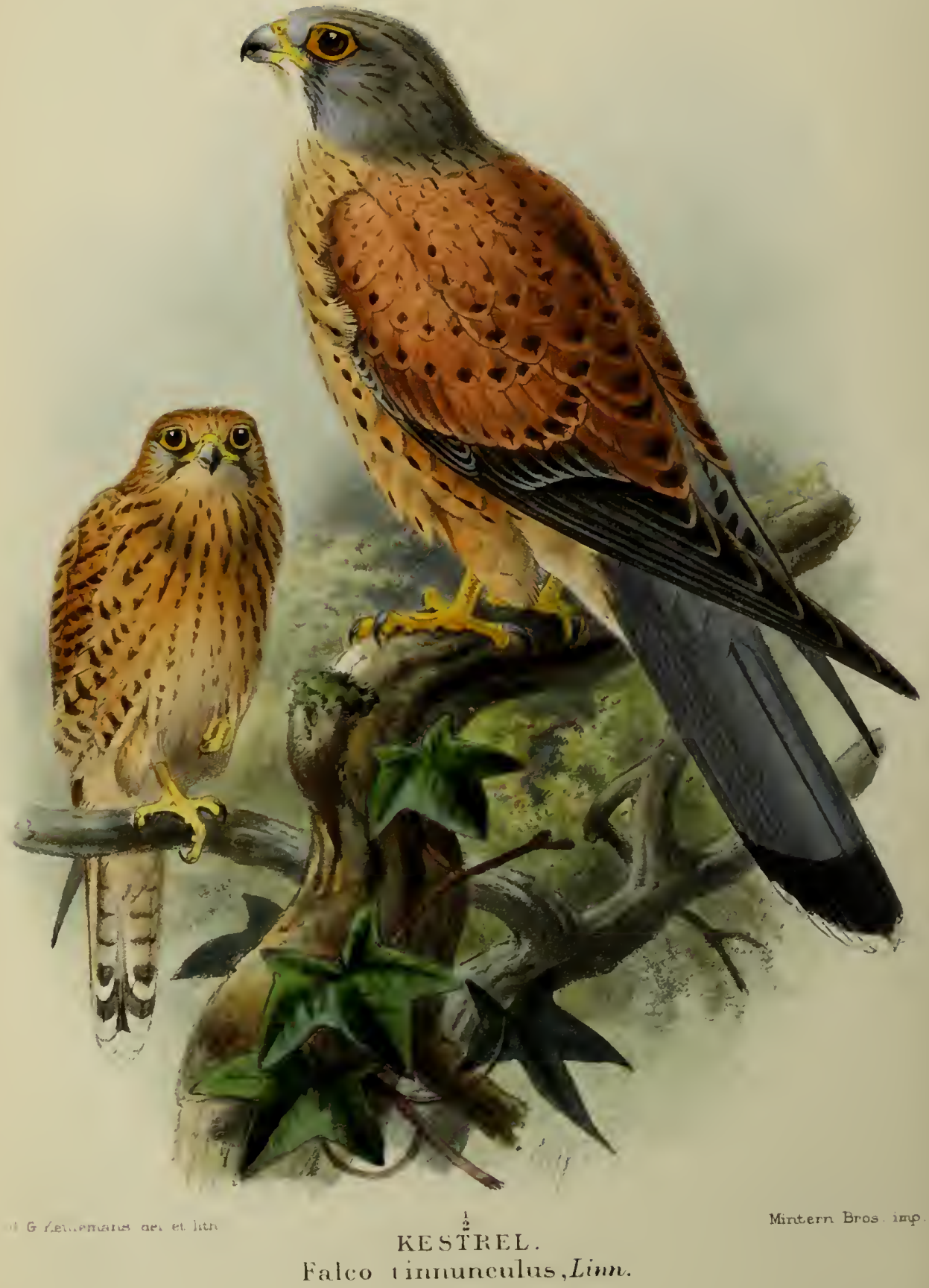




\section{KESTREL.}

FALCO TINNUNCULUS, Linn.

Falco tinnunculus, Linn. S. N. i. p. 127 (1766); Naum. i. p. 323 ; Macg. iii. p. 325 ; Hewitson, i. p. 32 ; Yarr. ed. 4 , i. p. 78 ; Dresser, vi. p. 113.

Faucon-cresserelle, French; Thurm-Falke, Rüttel-Falke, German; Primilla, Cernicalo, Spanish.

In spite of the senseless persecution to which it is exposed, this beautiful and interesting bird is still tolerably common in many parts of our country, and its habits are probably too well known to those who take any interest in birds to render any lengthened notice necessary at my hands. In the part of England with which I am best acquainted I consider the Kestrel to be a regular migrant, appearing in force in March; these birds pair shortly after their arrival, and generally take possession of an old nest of Crow, Magpie, or Rook. Throughout the early summer a horering Kestrel or two may be seen daily in our neighbourhood, and as soon as our meadows are cleared of their crops we often see five or six of these very ornamental birds on wing together diligently exaiminng the ground for the various animals that constitute their usual diet, e.g. 
volcs, field-unicc, frogs, grasshoppcrs, beetles, and earthworms.

Most of our Kestrels leave us towards the end of October, and during really severe weather we seldom see one; but in mild winters a few remain after the main body has passed to the south. In Northamptonshire the country-people generally call this bird "Sparrow-Hawk;" but gamekeepers have good reason to know the very obvious differences of habit and appearance between the present species and the bird that properly bears the latter designation. The Kestrel will now and then take a young game-bird on the ground; but the good service done by this species in the destruction of noxious animals, to say nothing of the beauty of its flight, ought to ensure it from slaughter in the supposed interests of sport. I know that it is almost useless to protest against the persecution of this, as any other species, by the emissaries of bird-stuffers and plume-dealers, the only hope that one may reasonably entertain in this connexion is for an improvement in taste and sense of deceucy.

The Kestrel is more or less common throughout Europe, and is exceedingly abundant in Spain, where it is to be found nesting in almost every church-tower or ruin in town and country in company with its very close congener-the Lesser or White-clawed Kestrel (F. cencliris). I need hardly say that the present species is useless for the purposes of falconry; but it is an interesting pet, and may be kept quitc tame in perfuct liberty. 



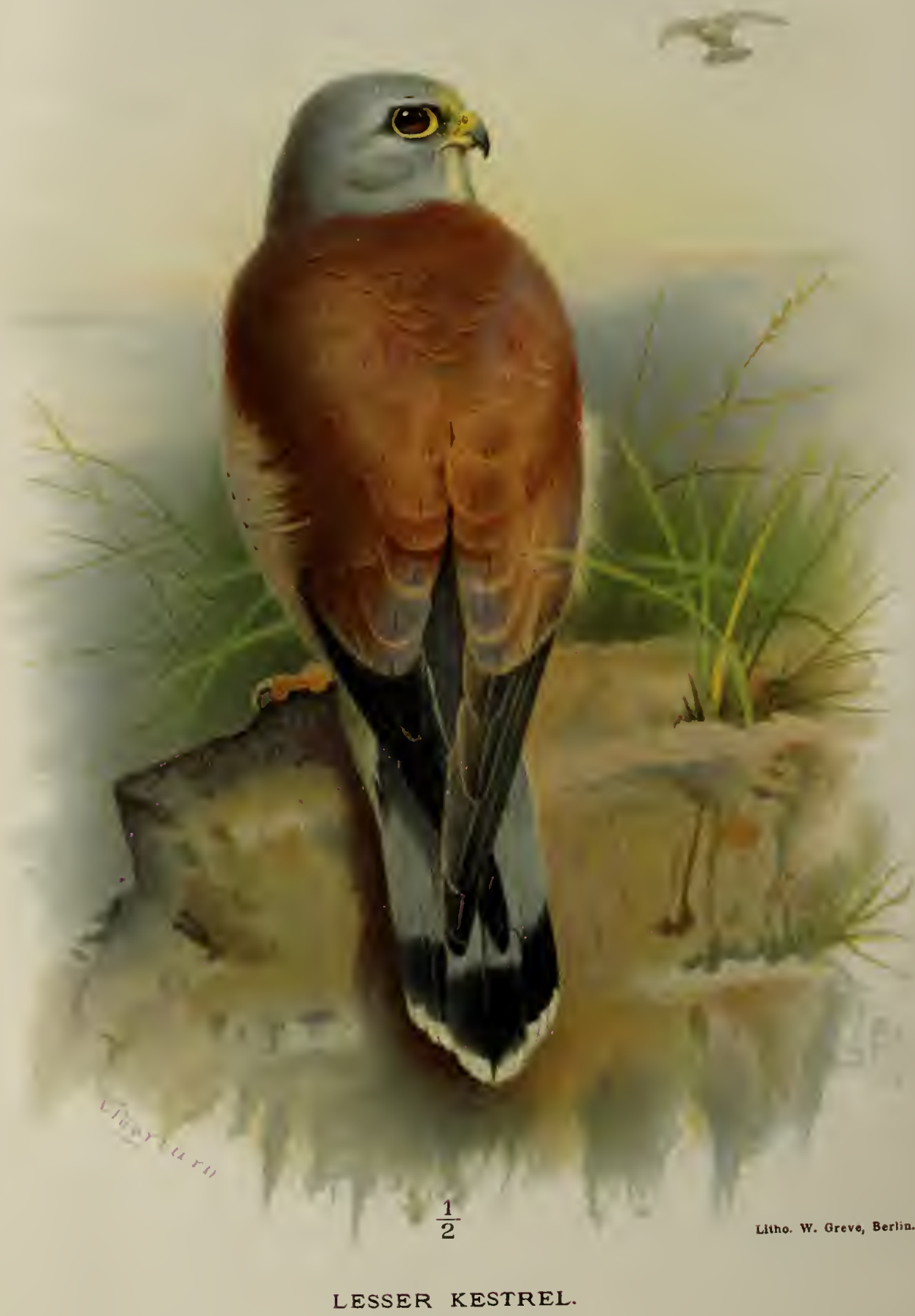

Falco cenchris, Naum. 


\section{LESSER KESTREL.}

FALCO CENCHRIS, NaUm.

Falco cenchris, Naum. Vög. Deutsch. i. p. 318 (1822); Yarr. ed. 4, i. p. 82 ; Dresser, vi. p. 125.

Crécerelle crécerellette, French; Röthel-Falke, German; Primilla, Primita, wrongly Cernicalo, Spanish.

This beautiful little falcon is a "Southerner," and its visits to the British Islands, and, indeed, to any part of Northern Europe, are exceptional and irrcgular. Mr. Howard Saunders, in his 'Manual,' records two occurrences of the Lesser Kestrel in England, one in Yorkshire in November 1867, and another near Dover in 1877; to thesc may be added that of an adult male killed near Shankill, Co. Dublin, on February 17, 1891, and another, of the same sex, shot during the first week of March 1891, in Tresco, Scilly; these two latter occurrcnces are recorded in the 'Zoologist' for 1891, pp. 152, 153, by Mr. A. G. More and Mr. J. H. Jenkinson respcctively. The Tresco specimen was most obligingly lent for the purposes of the present work by Mr. Dorrien Smith (to whom I am indebted for many valuable loans), and is the bird represented in the accompanying Platc. 
I may mention that the female of this species so closely resembles the Common Kestrel that I do not consider it necessary to give a representation of her, the only constant differences between females of these two species being the smaller size and the white claws of the present bird. The Lesser Kestrel abounds in Andalucia, and is also common in many districts of Central Spain; in general habits, flight, and cry it is barely to be distinguished from the larger species, but it is perhaps more exclusively insectivorous than the Common Kestrel, and rarely, in my experience, nests in trees. It is of course difficult to compute the numerical proportion of two very similar species when seen in the air together, but I am disposed to consider the Lesser Kestrel as more abundant in Andalucia during the summer months than its larger congener.

My kindly readers will, I trust, pardon me for summing up my remarks on the Little Kestrel by quoting from my own "Notes on the Ornithology of Spain" published in the 'Ibis' for 1865 :- " The two species of Kestrel are, I think, in April and May, the commonest birds in Andalucia, with perhaps the exception of the Bee-eater. Every church-steeple, belfry, and tower, every town and village, every ruin swarms with them; I believe I am not at all beyond the mark in saying that I have seen three or four liundred on wing at the same moment on more than one occasion, notably at Castro del Rio in April 1864. Both species of Kestrel continue on wing long aftcr dark." I would amend the last sentence by substituting the word sunset for "dark." The eggs of this species are of a lighter colour than the 
average productions of the Common Kestrel, and, naturally, considerably smaller; they are generally laid in holes of stone- or brick-work without any attempt at a nest, and I have several times found them witlin reach from the ground without any necessity for climbing to obtain them. A few Little Kestrels remain in Southern Spain through the winter months, but the great majority arrive in February or early in March, and leave the country about the end of September. 'The principal food of the Lesser Kestrel consists of beetles, locusts, and grasshoppers; to the best of my belief their prey is invariably taken on the ground. 



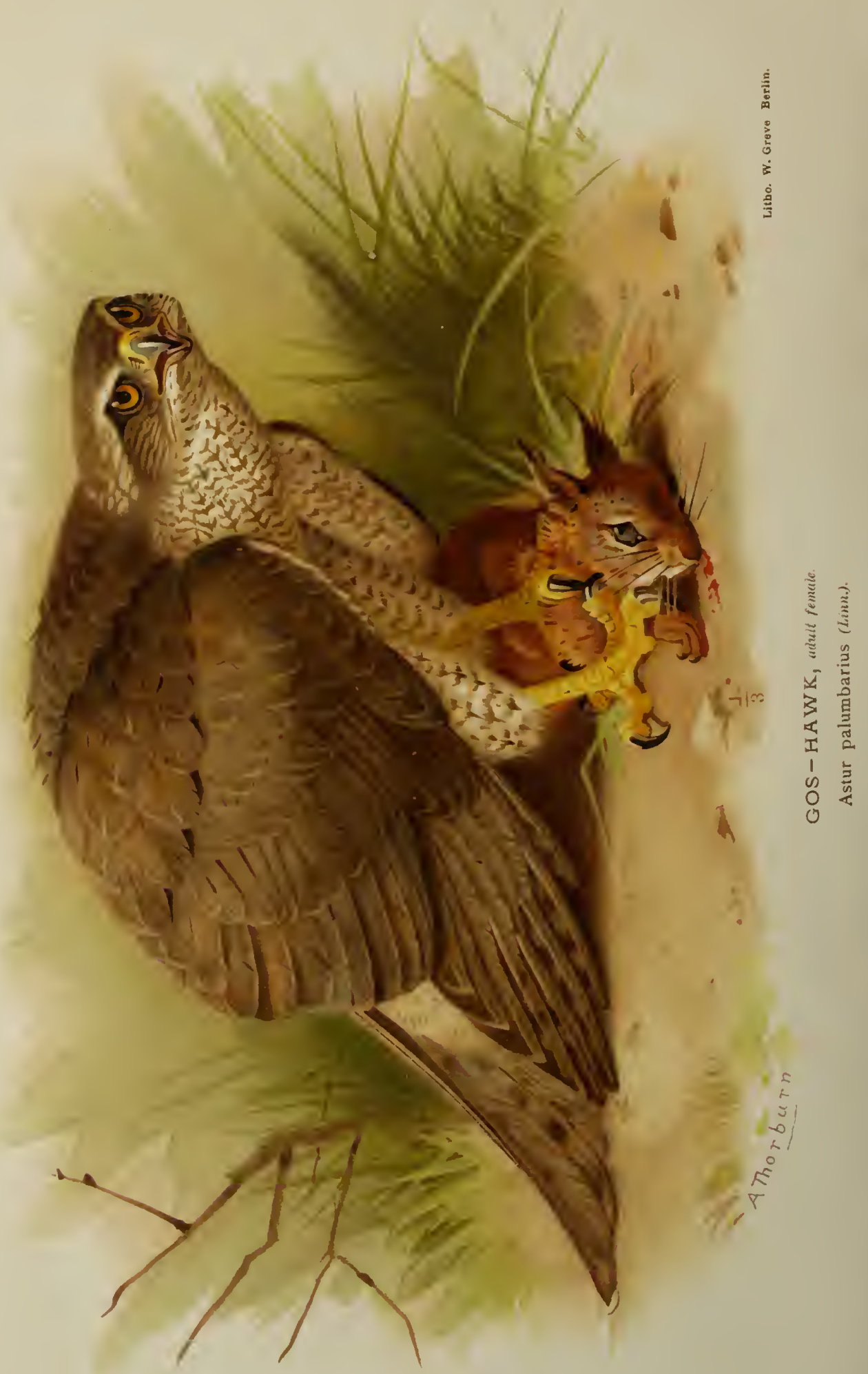




\section{GOS-HAWK.}

ASTUR PALUMBARIUS (Linn.).

Falco palumbarius, Linn. S. N. i. p. 130 (1766); Nuum. i. p. 249.

Accipiter palumbarius, Macg. iii. p. 340 .

Astur palumbarius, Hewitson, i. p. 34; Yarr. ed. 4, i. p. 83 ; Dresser, v. p. 587.

Autour, French; Habicht, German; Azor, Gavilan, Spanish.

Although this fine Hawk is by no means uncormmon in Germany and certain districts of Northern France, and there is good evidence of its having formerly bred in Scotland, it is now only known as a rare and irregular visitor to Great Britain, and I have only once seen a freshly-killed British Gos-Hawk; this bird I found on the counter of the shop of the well-known Mr. B. Leadbeater, of Brewer Street, about the end of March 1864, and was informed by him that he had just received it for preservation from Sir Robert Sheffield, Bart., of Normanby Park: several years after this the late Lord Kesteven mentioned this occurrence to me, and informed me that another Gos-IIawk was noticed at the same 
time about the same locality as that in which the bird above referred to was killed, and that an empty nest, supposcd to have been built by these Hawks, was discovered by Sir Robert's gamekeeper. In November 1888 the present Lord Kesteven was good enough, at my request, to make further inquiry into this matter, with the following result:-Firstly, a letter signed "Frank Sheffield," to the effect that "A Gos-Hawk was killed some 25 years ago, in the spring, on Sir Robert Sheffield's property by the head-keeper. A pair of Gos-Hawks frequented a large larch-plantation for some time, and the specimen shot, and stuffed by Leadbeater, was the female; a lirge nest was found near the place, and the male, though seen for a day or two following (the death of his mate), did not remain. The specimen is still at Normanby Park. Secondly, a letter addressed to Lord Kesteven by Mr. J. C. Sheffield, who, enclosing the letter just quoted from his brother, adds, "I also wrote to the gamekeeper at Normanby for information; he says, "My father shot the Gos-Hawk, but I cannot tell you the year, I remember it was the day before a Good Friday; there was another about at the time, but they could not get it, and some little time afterward we found the nest they had built in the Warren plantation, about 20 yards from where my father shot the bird at roost in a larch-tree." " This statement is unsigned, but Mr. J. Sheffield, in the same letter to Lord Kesteven, enclosed a note, dated Burton-on-Stather, Doncaster,

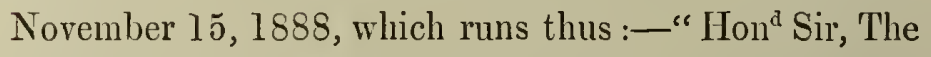
Gos-Hawk was killed March 27, 1864. I am, Sir, your ob $^{t}$ servant, JAs. Coultnurst, Jun." I do not think 


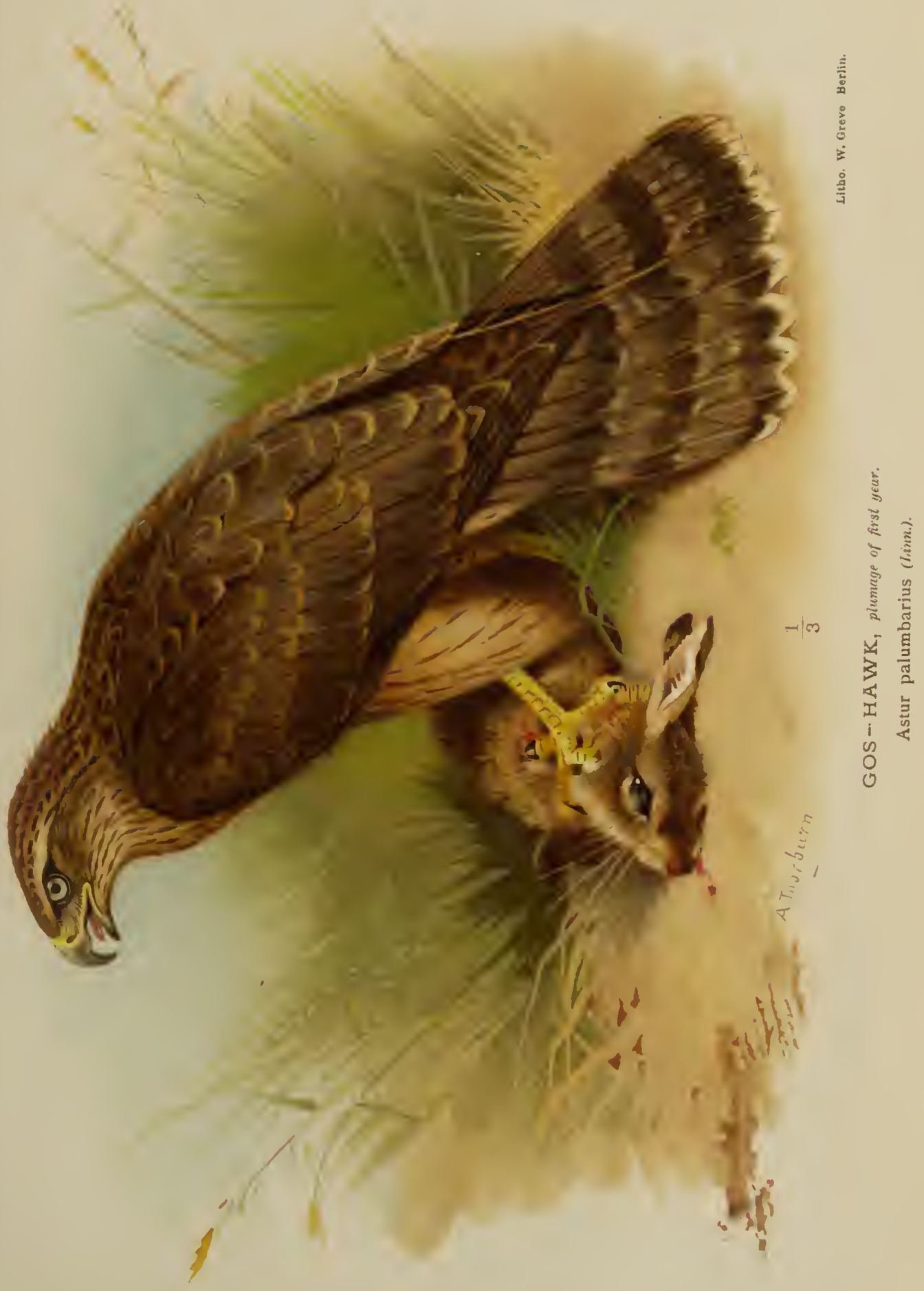



it probable that the nest alluded to in the above letters was built by the Gos-Hawks; but as this is the latest rccorded instance within my knowledge of a pair of these birds having been observed in company in England, I have given the full details of the occurrence as communicated to me. I may mention that Normanby is within a short distance of Brigg, in North Lincolnshire.

The Gos-Hawk is a forest-loving bird, and, in my experience, is especially addicted, though by no means cxclusively confined, to coniferous districts in the breeding-season; in most of its habits, as in general form and adult plumage, this bird closely resembles the Sparrow-Hawk, but it has a very decided tastc for mammalian "quarry," which is not apparently shared in by its smaller congener. A hungry Gos-Hawk will, as falconers say, "go at anything" that offers a chance, from a hare to a field-mouse, or from a Capercailzie to a Hedge-Sparrow, and, although its performanecs in a trained condition are, from a sporting point of view, liardly worthy of mention in comparison with those of the true Falcons, it cannot be denied that in very many parts of England a good Hawk of this species would keep the pot boiling for a family, who would starve if it had to depend upon captures made by the nobler bird. Failing a country adapted for Falconry in the restricted sense of the term, a good and well-trained "Gos" will afford a certain amount of sport and plenty of cxercise to her owner; but the manners and customs of this specics in a state of servitude to man have been so cntlusiastically set fortlu by a far more able and cxperieneed "Licensed Hawker" than nysclf in a most 
practical and excellent work, cntitled 'Falconry, its Claims, History, and Practice' (London, 1859), that I should find it difficult to avoid "cribbing" in dilating upon this aspect of the Gos-Hawk's character. The nests of this bird that I lave seen were large, rather shallow structures, placed on the lateral boughs of coniferous trees, at a considerable height from the ground, and composed of sticks and twigs; the eggs, three or four in number, are of a greenish white. My friend Col. E. Dehmé Radcliffe, a past master in Falconry and all matters relating to the habits of raptorial birds, assures me that in Germany the Gos-Hawks take many Owls, and I have always found my trained birds ready and eager to fly at Barn-Owls when they had a chance of doing so ; on one occasion my falconer found a Tawny Owl in the clutches of one of the Gos-Hawks at her perch in our flower-garden, and was in time to libcrate the incautious hooter almost uninjured; but, as I have alrcady said, hardly any flying or running animal that it can master comcs amiss to this Hawk, and the list of captures at various times by trained Gos-Hawks in my possession includes hares, rabbits, rats, squirrels, stoats, weasels, a cat, Owls, Blackbirds, Thrushes, Wood-Pigeons, Plieasants, Waterhens, and Wild Ducks. In one nest of this species in Old Castile we found a skull of a young Kestrel probably takcn from its nursery, and I have heard of instances in which young Honey-Buzzards have suffered a similar fate. I have met with this species frequently in the Guadarramas, less often in Andalucia, and in Switzerland and Rhenish Prussia during the summer months, and in the island of Sardinia and 
European Turkey in the winter. In common with most of the raptorial birds that breed in Northern Europe, many Gos-Hawks migrate southwards in autumn, and the range of this species extends from Lapland and Siberia to N. India and Algeria, and from Portugal to China and Japan.

Both the drawings for the accompanying Plates were taken from living birds at Lilford. 




\section{SPARROW-HAWK. \\ ACCIPITER NISUS (Linn.).}

Falco Nisus, Linn. S. N. i. p. 130 (1766).

Falco nisus, Naum. i. p. 258.

Accipiter nisus, Macg. iii. p. 310; Hewitson, i. p. 35 ; Yarr. ed. 4, i. p. 88 ; Dresser, v. p. 599.

Épervier, French; Finken-Habicht, German; Gavilan, Milano jaspeado, Spanish.

A very common resident in almost all parts of Great Britain and Ireland.

The Sparrow-Hawk, in common with almost all the raptorial birds of Northern Europe, follows the irregular partial autumnal migrations southwards of the small birds upon which it preys.

The four Plates represent an adult and a yearling female, and males of the same respective ages.

I have not been able to procure a very old female, in which the plumage closely resembles that of the adult male. 


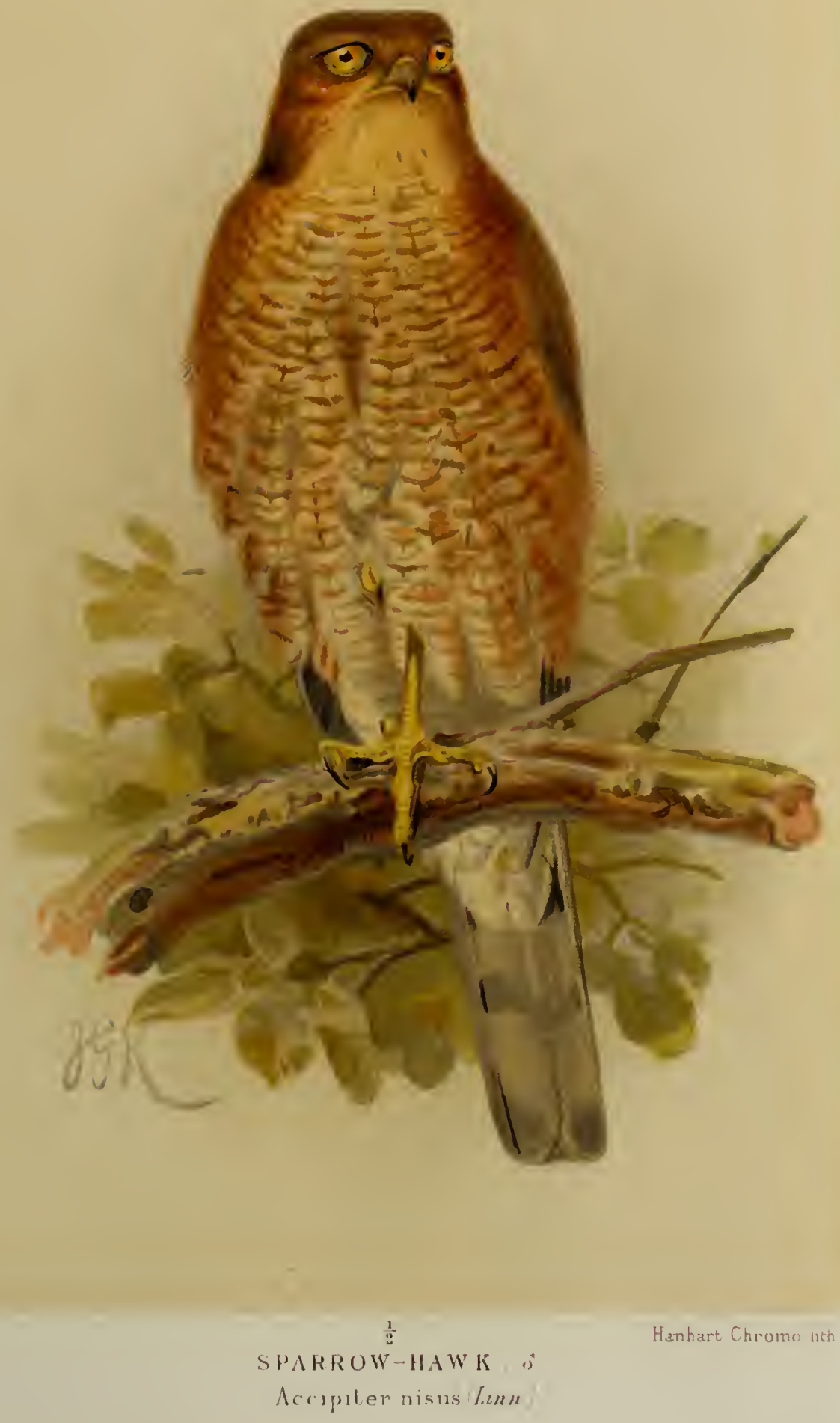





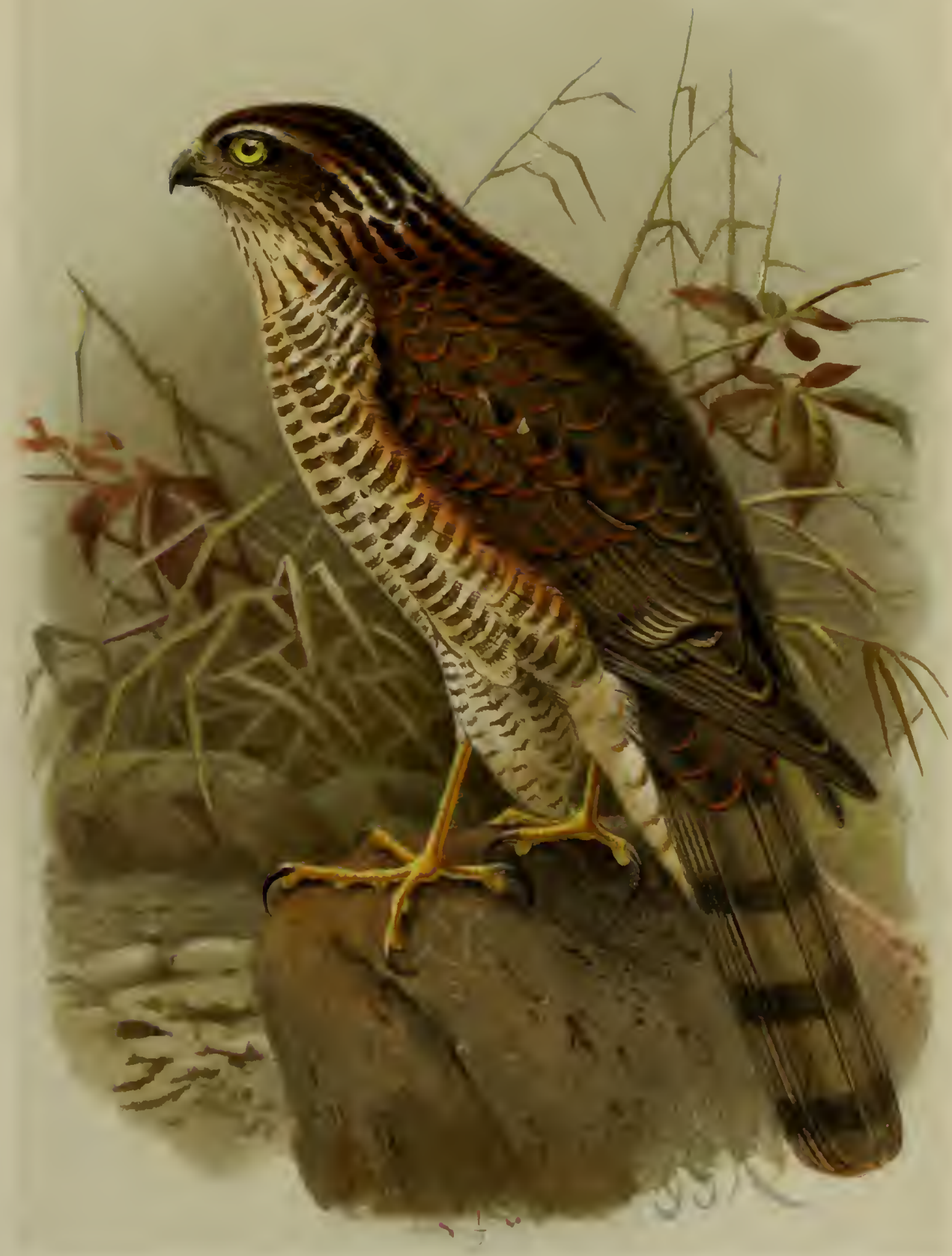

SPARROW-HAWK (male immature)

Accipiter nisus (I inn) 



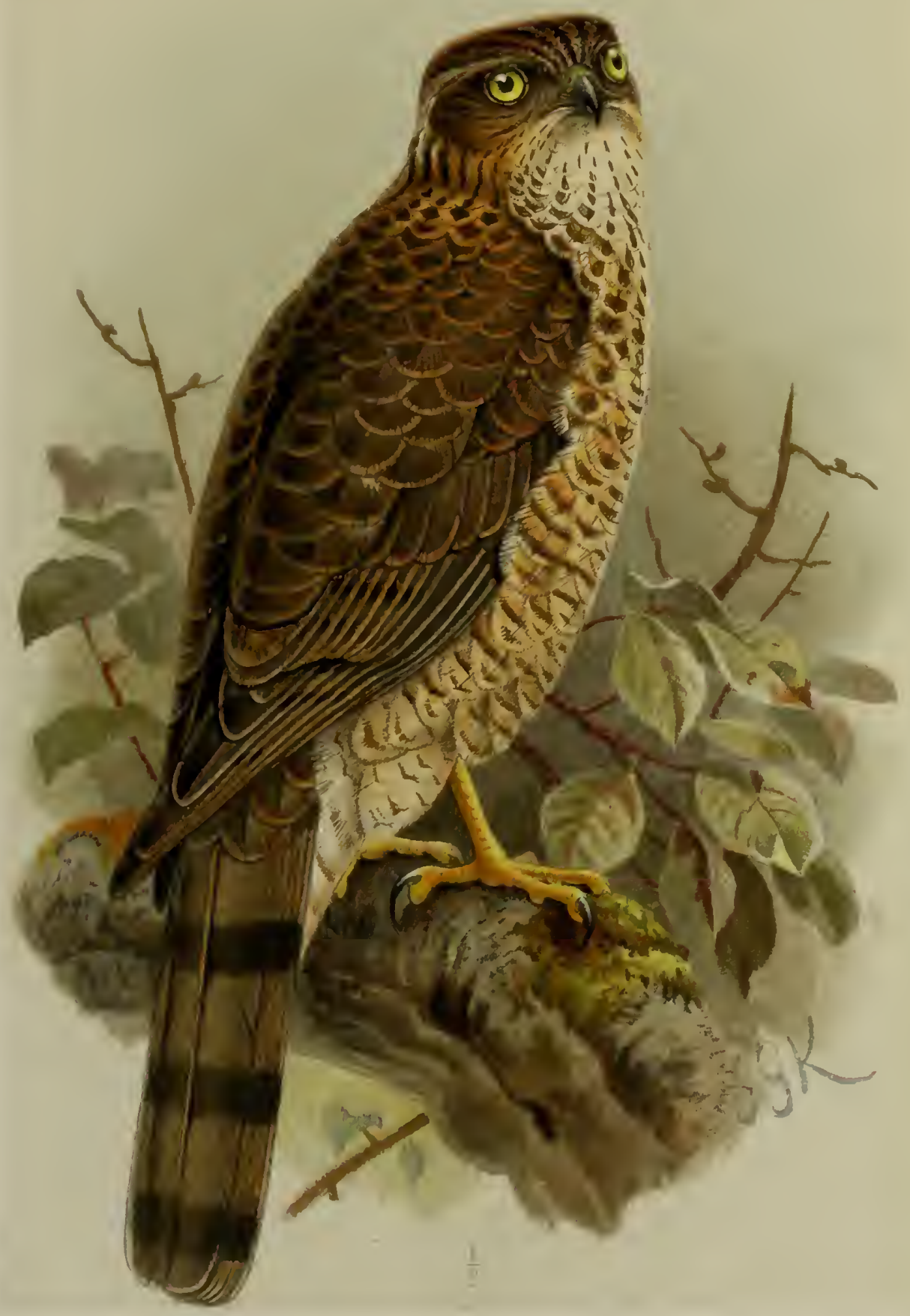

SPARROW-HAWK (female immature)

Accipiter nisus (Linn.) 








\section{MAPSH-HARRIEP}

CIRCTS ERTGINOSTS Linn.).

Falco æruginosus, Linn. S. N. i. p. $130(1 ; 66)$.

Falco rufus, Noum. i. p. 378.

Circus æruginosus, Mecg. iii. p. 3.92; Yerr. ed, t, i. p. 1:27;

Dresser, v. p. 415 .

Circus rufas, Hercitson, i. p. 14.

Busard des marais, French; Rohr-IVeike, German; Aguilucho, Rapiñe, Spanish.

This bird, which was formerly common and resident in most of the extensive fens and marshes of England and Ireland, is now comparatively seldom to be met with, owing, of course, to the reclamation of many of its ancient strongholds, and the sedulous attentions of gamekeepers and bird-collectors. It is still abundant in almost all the great marshes of Central and Soutbern Europe. I hare seen twenty-sir on wing together in Epirus, and in the lomer marisma of the Guadalquirir more or less of this species are constuntly to be seen searching for prex along the reeds that fruge the rirer, or skimming low over the rast muddy plains that estend to the horizon. The plumage depicted in the first of the two accompanving Plates is that of a rery o!d male 
bird, and it seems that very fe.r specimens have been obtained in this dress in our country. The other Plate represents a bird in its first year, and was taken from a living specimen at Lilford.

The Marsh-Harrier is almost omnivorous, and particularly addicted to devouring eggs; most of my reader's who have pursued Snipes in the south or east of Europe will agree with me in considering the present birds as unmitigated muisances, not only on account of their carrying off any wounded Snipes, but also because their continual harrying of the ground often renders the Snipes unapproachable, or drives them right away. In our fen-country this bird was generally known as the Moon-Buzzard, and I have heard marvellous stories of its former abundance and depredations in the neighbourhood of Whittlesea Mere; now I do not suppose that a Moon-Buzzard is to be seen in that district more than once perhaps in three years. I have myself seen several of this species in the "Broad" country of Norfolk, one in Cambridgeshire, one in Northamptonshire, and many years ago a good many in Ireland and Wales. 


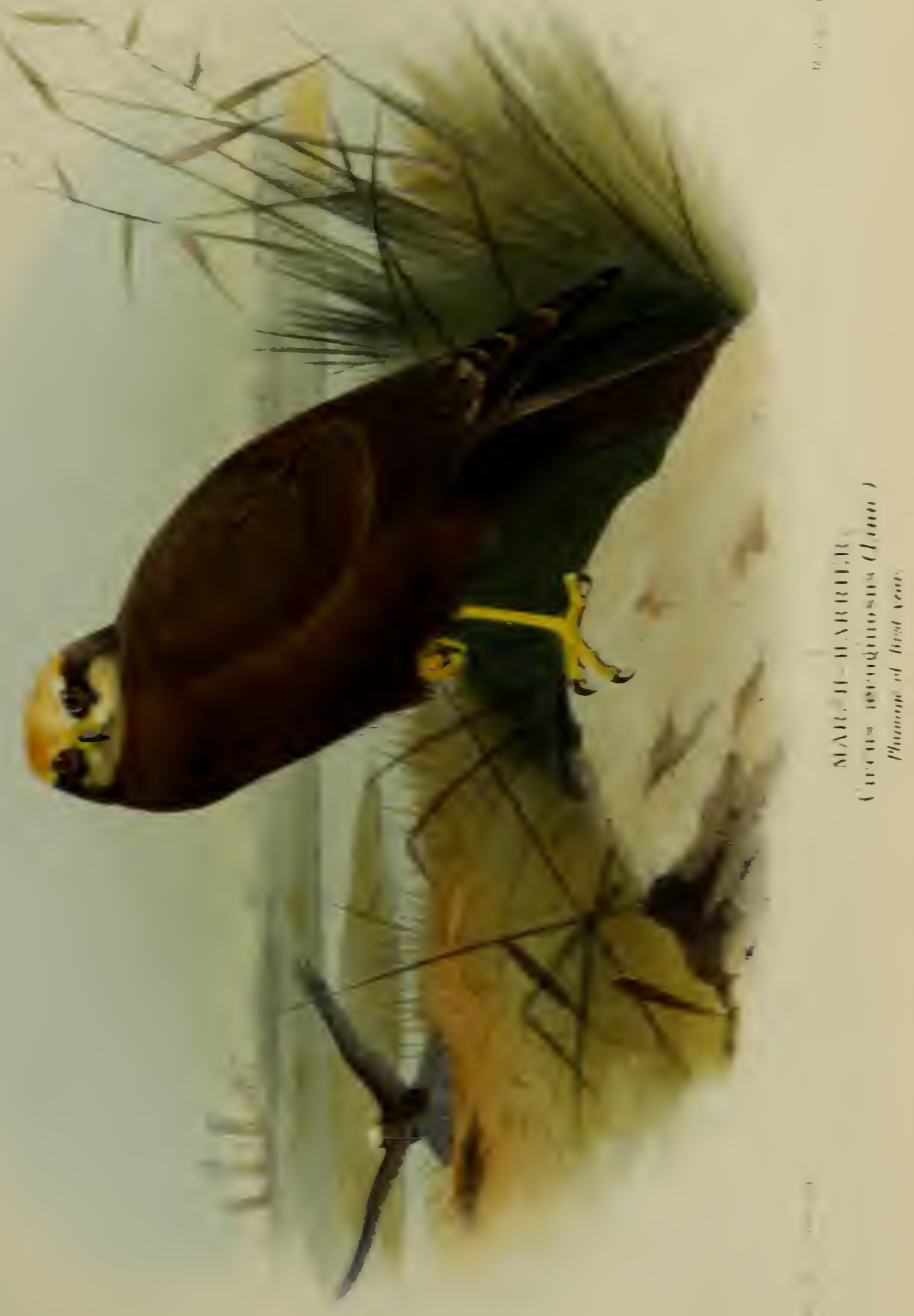






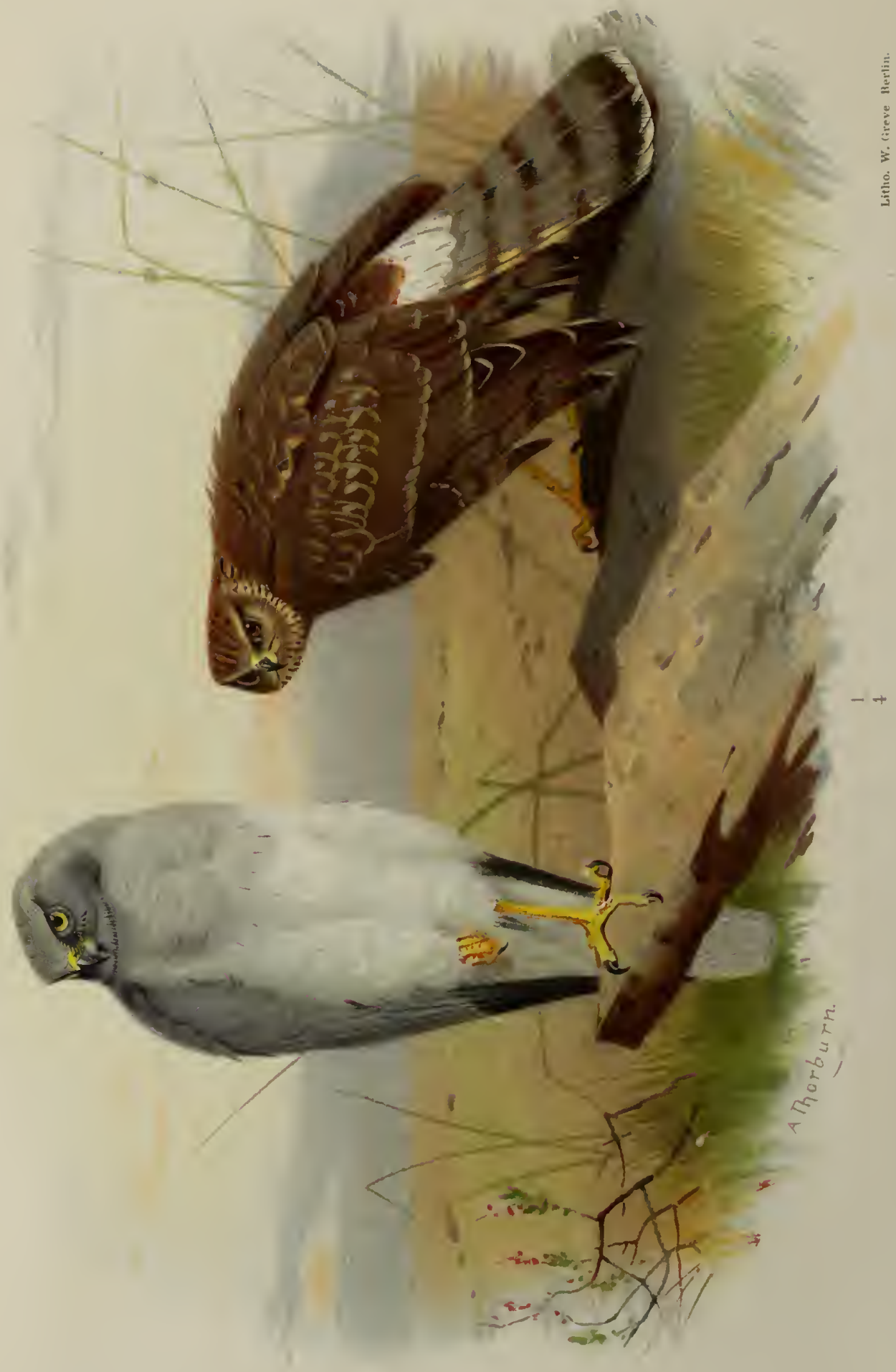

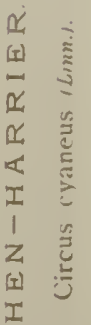




\section{HEN-HARRIER.}

\section{CIRCUS CYANEUS (Linn.).}

Falco cyaneus, Linn. S. N. i. p. 126 (1766).

Circus cyaneus, Macg. iii. p. 366 ; Hewitson, i. p. 47; Yarr. ed. 4, i. p. 132 ; Dresser, v. p. 431.

Falco pygargus, Naum. i. p. 391.

Busard St.-Martin, French; Korn-Weihe, German ; Cenizo, Spanish.

This bird, which formerly was to be met with more or less frequently in all the uncultivated districts of any extent in the British Islands, is now, with the exception of a few localities, only known as a casual and by no means a common bird of passage. Every man's hand is against the Harrier, not only on account of its ravages amongst young poultry and game birds, but also because eggs of all sorts are a very favourite dainty with all the European members of this family; to what extent the Hen-Harrier may atone for delinquencies of this kind by the destruction of mice and voles $\mathrm{I}$ am unable to say, as my acquaintance with this species in cur country is very limited. I have, however, had ample opportunities for observation of the habits of the Hen-Harrier abroad, and it is from my foreign experiences that I mainly quotc in the following remarks. 
'I'his bird is essentially a frequenter of the open country, be it heath and furze-clad common, fen, or corn-land: the nest is usually, if not invariably, placed on the ground, on a bare spot amongst furze, heather, or sedge; in certain localities a field of growing wheat, barley, oats, or rye is often selected as a secure nestingplace, the essentials being concealment and security from disturbance. The few nests of the Hen-Harrier that I have seen were composed entirely of dry sedge or coarse grass, very loosely put together. 'The eggs, three or four in number, are of a very pale blue-green, often freckled with specks of light rust-colour; the young birds can generally fly about the end of June. During the sitting-time the female Harrier is fed by the male, who drops the prey to her as he hovers abovc her; this is done so instantaneously that to any one watching from a distance the action is hardly perceptible. Besides the localities to which I have refcrrcd the Hen-Harrier habitually nests in undrained fenlands amidst reeds and sedge; but, as a rule, I consider this species, from my own acquaintance with it, as less of a marsh bird than either of the other two British Harriers. In quest of food the Hen-Harrier is most systematic, regularly frequenting the same spots day after day about the same hour, and quartering the "beat" in every direction in an apparently desultory but virtually most thorough-going fashion. The flight of this species is very light and buoyant, and as noiseless as that of the larger Owls. A friend, who is a most cxccllent observer and specially acquainted with raptorial birds, informs me that when a Hen-Harrier 
puts a covey of Partridges into a fence for concealment it takes its "stand" hard by on some perch whence it can command the situation, and remains perfectly motionless till some movement on the part of one of the covey betrays its whereabonts, when the Harrier is down on it in a second, and the career of the game bird is at an end. All the Harriers are especially fond of frogs and lizards, and some of them often capture and devour small snakes.

In captivity I lave found this species wild, sulky, and by no means easy to keep in good health. In Devonshire this bird, and probably Montagu's Harrier also, are, or were, commonly known as "Vuzkits," i.e. Furze-Kites; in Ireland they have been pointed out to me as "Gos-Hawks," no doubt properly GorseHawks; and in Scotland I have heard the male called "Blue Glead," and the female distinguished as Ringtail. 




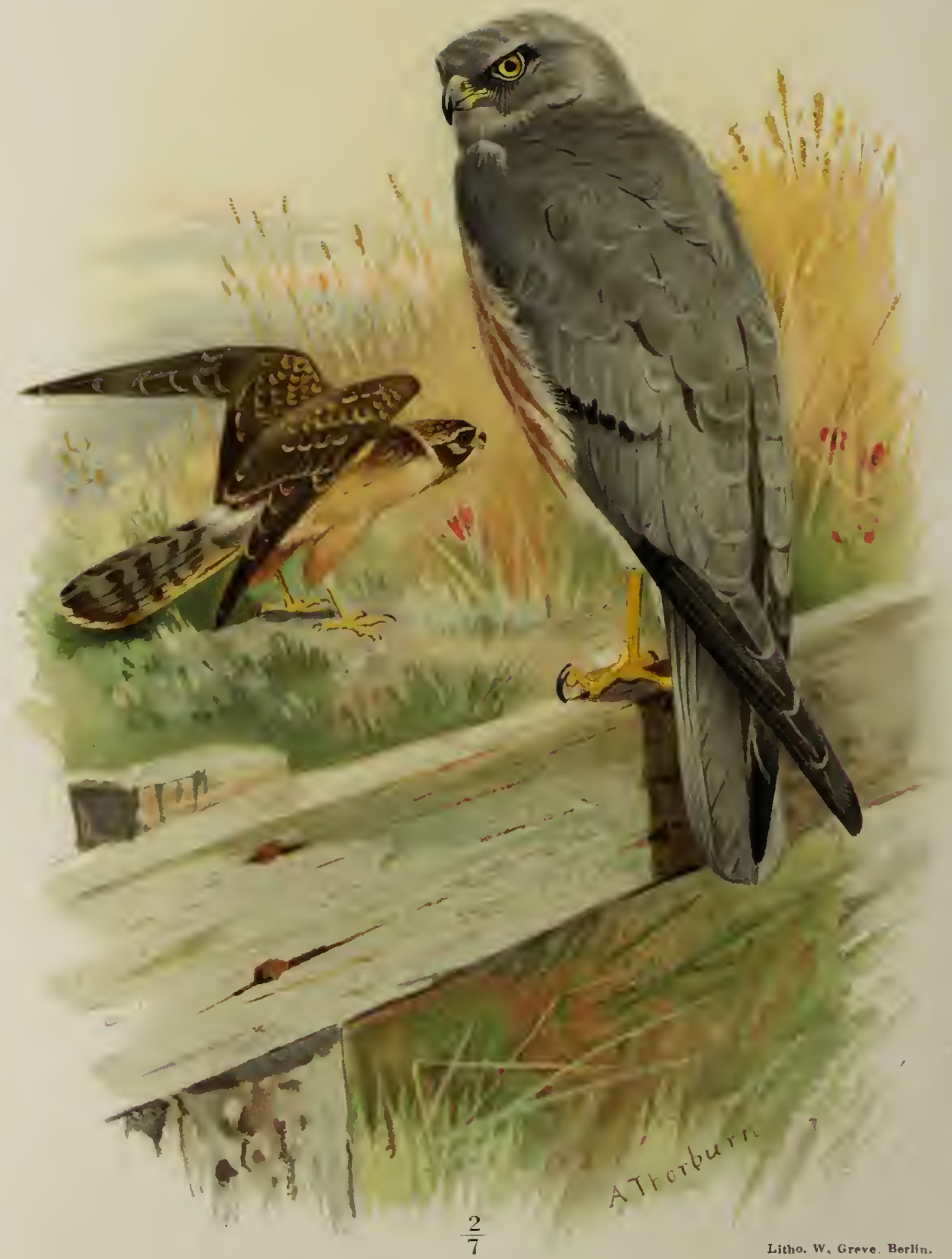

MONTÄGU'S HARRIER. Adult and immature, males.

Circus cineraceus (Montagu). 


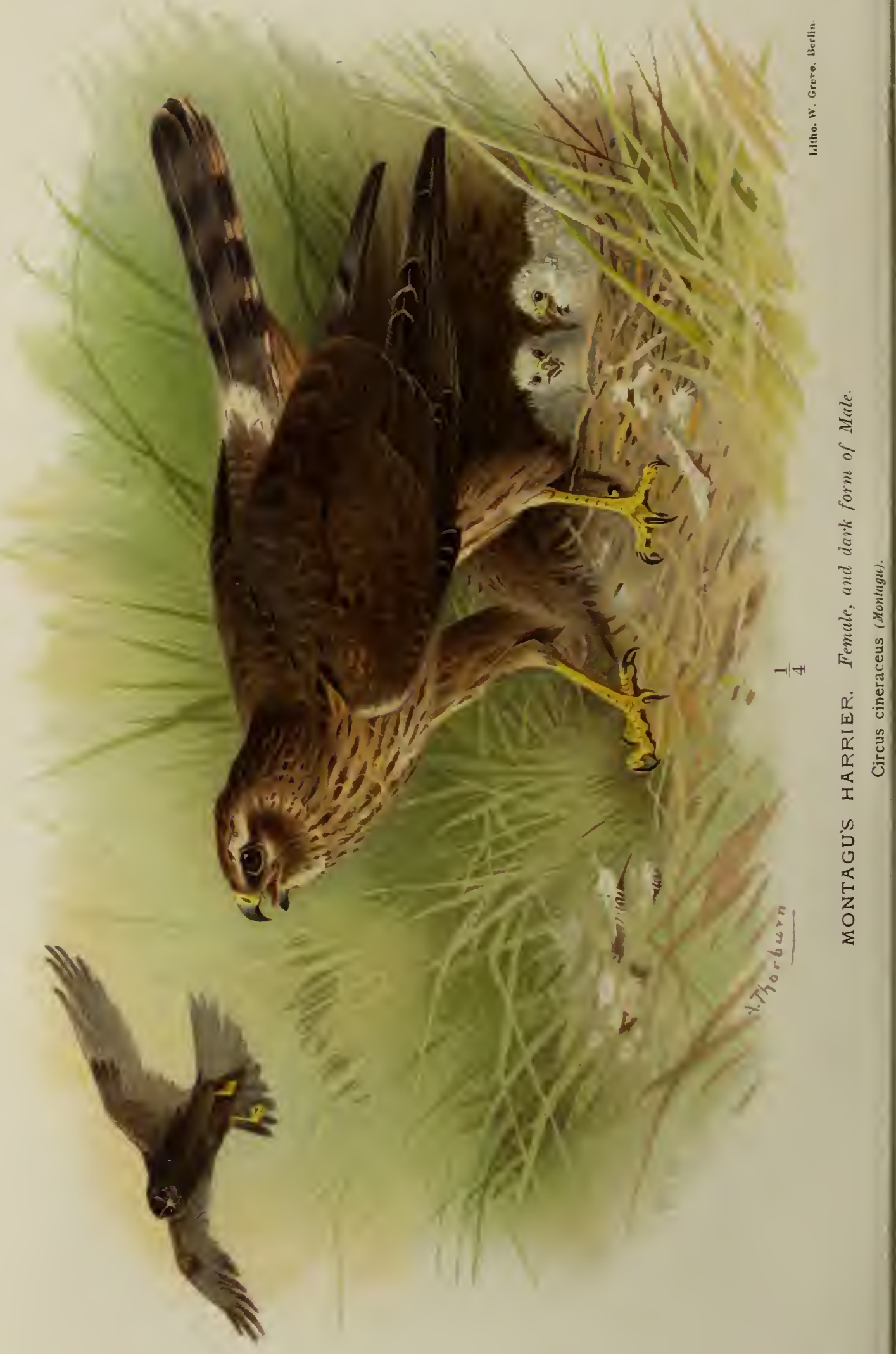




\title{
MONTAGU'S HARRIER.
}

\author{
CIRCUS CINERACEUS (Montagu).
}

Faleo cincraceus, Montagu, Orn. Dict. i. F. 2 (1802); Naum.

i. p. 402 .

Circus cineraceus, Macg. iii. p. 378 ; Hewitson, i. p. 49 ; Yarr. ed. 4, i. p. 138; Dresser, v. p. 423.

Busard cendré, French ; Wiesen-Weihe, German ; Cenizo, Rapiña, Spanish.

This species was first distinguished and separated from the Hen-Harrier by the acute naturalist whose name it bears, in his 'Ornithological Dictionary,' published in 1802, under the name of Ash-coloured Harrier, Falco cineraceus. No raptorial bird has now a chance of becoming common in this country, but I suspect that in the southern counties of England, at all events, this Harrier was formerly the most abundant of its genus during the summer months, as it most assuredly is at the present time, although it generally meets with "short shrift" from gamekeepers and collectors. I am, however, glad to say that I am personally acquainted with several recent instances in which nests of Montagu's Harrier have been carefully protected by those most nearly concerned, and the young birds allowed to grow 
and take wing without molestation. As no good cause is promoted by over-statement, I will not attempt to deny that all the Harriers are egg-stealers, but. I would at the same time remind game-preservers and our unfortunate British agriculturists, that these birds are very active and sharp-eyed enemies to field-mice, moles, and voles. To the "British bird-collector," I fear that any appeal on behalf of a comparatively scarce bird is only a waste of time, and I can only say that these Harriers, in my opinion, add greatly to the beanty and interest of the moor-lands and marshes that still exist in our overcrowded country. Montagu's Harrier is a summer visitor to those parts of Europe in which it breeds, and, when allowed to livc, leaves our Islands in October. A certain number of this species, howerer, visit this country from the Continent on the autumnal migration, and (I write under correction) most of the records of occurrence at that season refer to birds of the year. 'To those acquainted with the four European Harriers, the adult males of this species may easily be distinguished from those of the Hen-Harrier by their darker colouring, their greater comparative length of wing, and their more buoyant and irregular flight; and having stated this, I can write positively of having seen old male Montagu's Harriers on several occasions in Cambridgeshire, Norfolk, and Devonshire. I never had the good fortune to find, or even to see, an occupied nest of this bird in England, and it was in Southern Spain that I first became intimately acquainted with it in its breeding-haunts. It arrives in Andalucia in April, and for some time after its arrival seemed (in my experience) to remain in 
suitablc localities near the sea; as the season advances these birds continue their journey, generally singly or in pairs, up the valley of the Guadalquivir and nest abundantly in the great marshes and corn-lands below Seville. On one occasion, when posted in a pit in the open "marisma" for Great Bustard shooting, I noticed at least seventy of the present species passing steadily to the northward, evidently on migration, within shot of me, besides many at various greater distances; these birds, without exception, flew within a few feet of the ground, without pausing to hunt or rcconnoitre the territory, and were, in my opinion, all bound for some special breeding-places already determined upon in what I must call their minds. 'This was the only instance in which I ever witnessed a numerous "passage" of these Harriers, but I have several times observed one or two crossing the open sea. Once established in their nesting-quarters, these birds are constantly to be seen scouring the country in all directions, now and then hovering for a few moments, and occasionally alighting to devour or to pick up some prey. They are easily attracted by an imitation of the call of the Quail, and no doubt catch many of those birds upon the ground; but I do not remember ever to have seen one of these Harriers in pursuit of any flying fowl, and I know that in Andalucia their diet consists chiefly of frogs, lizards, various insects, worms, small rodents, and the cggs of ground-breeding birds. Colonel Irby, in his 'Ornithology of the Straits of Gibraltar,' mentions that he found a regular "colony" of this spccies breeding on a salt marsh in Morocco, and I anl assured of such cases in 
Spain, but personally I never knew of more than three or four nests in close proximity: these nests are generally placed upon bare ground in small open spots amongst low vegetation in the dry marslies, or amongst the stanuling corn; we never found one in the reed-beds that are so dear to the Marsh-Harrier. A few dry twigs or pieces of reed-stem, with a lining of sedge, are the usual nesting-materials. The eggs are white with a very slight greenish-blue tinge, and occasionally show a few pale rust-coloured spots; four is the usual complement. I feel certain that the male bird occasionally takes his turn at incubation.

The dark brown or black variety figured in one of my Plates is by no means uncommon: I have at this time of writing, November 1893, a very fine living specimen of this race received during the past summer from a nest in France; in this individual the irides are very nearly as dark as the pupils, and exhibit a marked contrast in this respect to those of its companion of the same species but of the normal type of plumage, whose irides are pale yellow.

This Harrier, according to Yarrell, has a wide range, and has been recorded as occurring in Caithness, Ceylon, the Canaries, and China. I have frequently observed this bird from the train whilst travelling through France in the summer months. I was assured by the late John Barr that he took several Montagu's Harriers near Chalons-sur-Marne with the trained Falcons belonging to the Champagne Hawking Club, during his term of service as falconer to that society. A few of the present species spend the winter in Andalucia. 



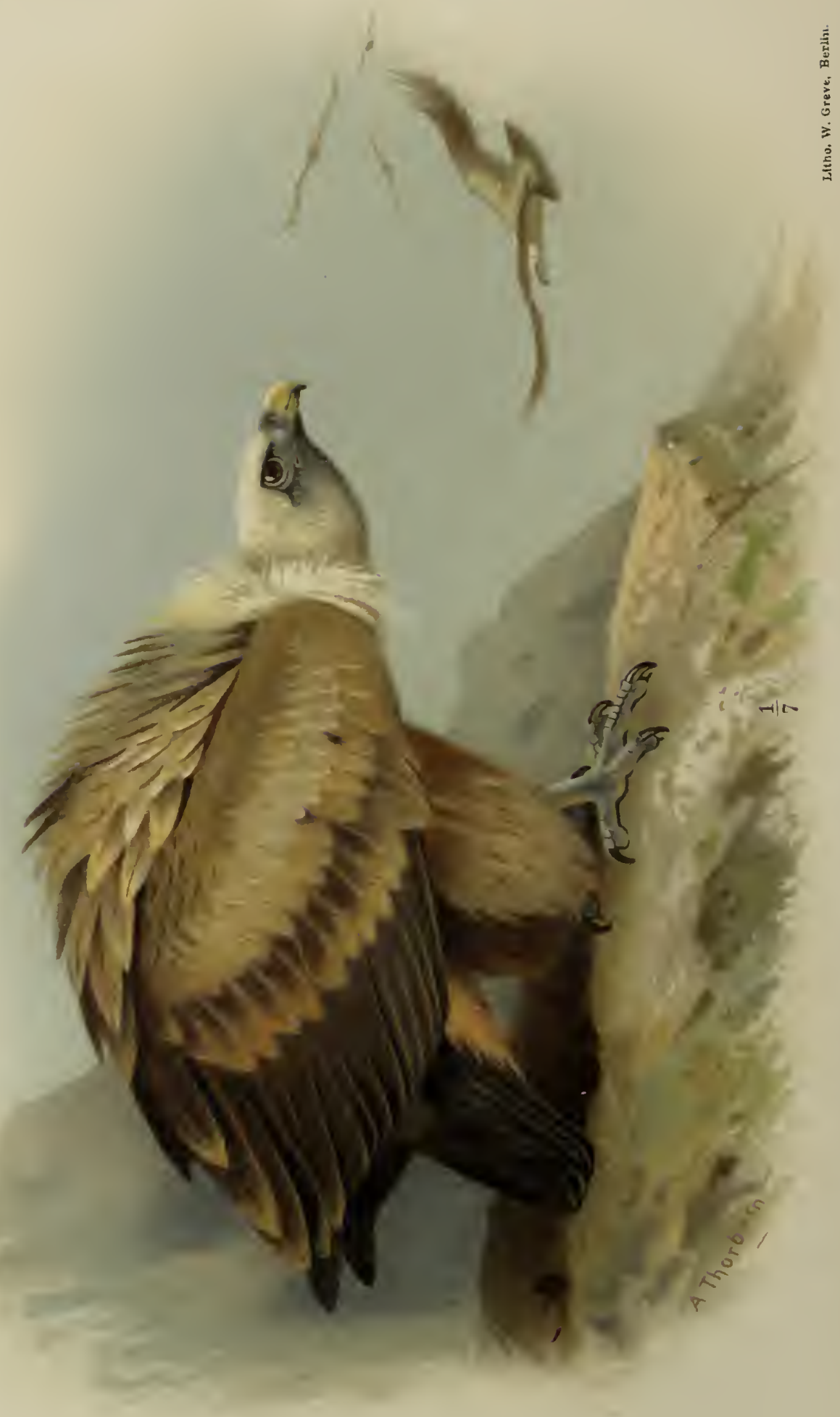

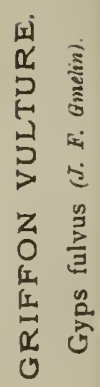




\section{GRIFFON VULTURE.}

GYPS FULVUS (J. F. Gmelin).

Vultur fulvus, Gmelin, Syst. Nat. i. p. 249 (1788) ; Naum. i. p. 162 ; Hewitson, i. p. 3.

Gyps fulvus, Yarr. ed. 4, i. p. 1 ; Dresser, v. p. 373.

Vautour Griffon, Trench; Weissköpfiger Geier, German; Buitre, Pajaraco, Spanish.

One capture only of this Vulture has hitherto been recorded as laving occurred in our Islands; the individual in question, now preserved in the Museum of Trinity Collegc, Dublin, was caught alive near Cork Harbour in the spring of 1843. Although this specimen is undoubtedly, as Mr. H. Saunders says, in immature plumage, I here give a representation taken from life of a fully adult bird, for the reason that Gould, in his 'Birds of Europe,' figurcs an immature bird of this species, and, with all due dcference to my friend Mr. Drcsser, I cannot consider that the excellent first plate of this bird in lis work was taken from a very old specimen. It must, however, be remembered that "old" is, with regard to Vultures, a very indefinite term ; personally I should not consider a Griffon Vulture fully mature till it had attained the agc of at least seven or eight years. 
With regard to the probability of the Irish specimen having escaped from captivity, I can only say that there is nothing in any way impossible in its having found its way voluntarily from the north of Spain, where the species is locally very common; a flight of three or four hundred miles would hardly overstrain the stayingpowers of a Griffon, even on the supposition that it came to Ireland straight across the sea from the Cantabrian Mountains. The reason of its visit is difficult to conjecture, as I imagine that unburied remains of animals must have always been more abundant in the neighbourhood of the bird's home (supposing him to have been of Spanish origin) than in the "distressful country," even in the worst of times. I may here say that the details of another occurrence of the Griffon, alluded to by Mr. Saunders in his 'Manual,' are well known to me, and that I have not the slightest doubt as to correct identification in this instance. I can claim an intimate acquaintance with the present species in Spain, Sardinia, North Africa, European Turkey, and Cyprus, and have also observed it rarely in Northern Italy, in Sicily, and in Crete. The Griffon Vulture and its habits in Spain, Nortl Africa, and Palestine have been so fully and so ably described by Colonel Irby, Canon Tristram, Mr. O. Salvin, and other writers, that to give details of my own experience on the subject would be little more than vain repetition. I will therefore only summarize from my notes and journals on the subject with regard to the first-mentioned of these countries,-my wellbeloved Spain. There is, I imagine, hardly a square mile of Andalucia from which it would not be possible to 
observe one or more of these Vultures on any day of the year; in Central Spain also the Griffon is common enough in all suitable localities, although perhaps not so abundant there as the Cinereous, or so-called "Black" Vulture (Vultur cinereus). I lave seen it in Galicia occasionally, and found it nesting in large colonies on the frontiers of Asturias and Santander, as also in Guipuzcoa and Navarra. In Aragon, Cataluña, and Valencia it did not appear to me to be so abundant as in the other provinces. 'The Griffon is naturally a bird of the Sierras, and, although constantly to be met with in the plains at all seasons, its visits thereunto are induced solely by "questions of supply." The ancient idea that Vultures find the carcases that furnish their almost exclusive diet by scent lias long been exploded. Mr. Saunders has pithily summed up their system of telegraphy in about three lines, for which I refer my readers to the oft-quoted 'Manual.'

The Griffon Vulture makes a large nest of sticks and grass, and lays one or two white eggs, generally about the end of February. The nests are usually placed on the ledges or in the cavities of weather-worn ranges of cliffs, and as several, ofteu many, pairs of these carrionfeeders nest in close proximity to each other, and there is almost always a gathering-place for the unemployed of their community in the immediate neighbourhood of the breeding-establishment, it will be readily believed that many wild and picturesque mountain-gorges in Spain lack the charm of fragrance during the season of flowers-in fact, these Vulture-haunted cliffs smcll most abominably, in spite of the frequent abundance of 
aromatic shrubs at their bases. The young Griffons remain in their nests till June, and, although I am well aware that these birds can live without suffering from a want of food for almost incredible periods, it is a constant subject of wonder how the great numbers that inhabit Southern Spain can possibly find the means of subsistence. To those who have never visited a country where Vultures are virtually the only efficient inspectors of nuisances and scavengers, it will perhaps be difficult to believe that in Andalucia I lave very frequently seen more of this species at the same time than I could possibly count, soaring in concentric circles, tier above tier, if I may use the term, over the carcases of horned cattle and horses. A more disgusting sight than some twenty or more of these huge birds tearing at and quarrelling over the remains of a semi-putrid beast can hardly be imagined, but on wing, and high in air, the Griffon is a magnificent bird as he sails for hours at a time with hardly any perceptible motion in the splendid deep blue of an Andalucian summer sky. I have called the eggs of this species "white," but some specimens show blotches and spots of iron-rust colour. I am not aware that the Griffon in Europe ever nests in trees, or, indeed, in any other locality than cliffs; but, although the nests are generally very difficult of access, this is by no means invariably the case. The subject of the Plate was taken from an isolated nest near Irun in May 1867 by a shepherd-lad who clambered up to it from below, and to his and our own astonisliment met us prepared for the capture of the nestling with ropes and a hired climber at the top of the cliff. We lad started from 
San Sebastian under the guidance of an English friend, who had discovered the nest some days previously, and had engaged mules, climber, and ropes at Irun for the attack, having to make a considerable detour to reach the summit of the scrub-covered range of cliffs above the coveted object. On approaching the spot from which we intended to commence operations, we becamc aware of both the parent-birds in evident agitation, sailing about at a level with the top of the cliff, and we had liardly reached it, when a merry young Basque appeared singing and swinging the young Griffon in one hand. We added to his hilarity by giving him a small silver coin, a cup of wine, and a handful of tobacco in exchange for the young Vulture, which we carried back to San Sebastian. I was bound on an expedition through Navarra and into Aragon, and left our not very fascinating prize in charge of the daughters of our host of the 'Parador Real,' hardly expecting ever to see it again, as these damsels, although most obliging and attentive to their gucsts, could not be supposed to take much interest in a strong-smelling and ugly carrionbird, belonging to a stranger. I crossed the frontier on my return to England by another route, scnding a servant to enquire after my Vulture, and bring it on, if alive, to meet me at Bordeaux; to my surprise and plcasure, he found the bird in perfect health, vcry much grown, and quite tame, and assured me that the "Señoritas" had parted with thcir charge with tears and all manner of caresses, that might wcll liave becn bestowed on more appreciative objects. I, however, had, and still have, good reason to be grateful for the 
care bestowed upon "Carlista," as I called my Griffon, for it is still alive and well at Lilford as I write,-in February 1893. This bird, since its arrival at Lilford, has shared a compartment with a Cinereous Vulture taken in Spain in 1865, and for many years past has annually assisted this bird in making a nest, in which the latter generally has deposited two or three eggs. I am convinced that the Griffon has no share in the production of these eggs, in fact, I am by no means certain that it is not a female, but, as the end of February approaches, it becomes quite as savage as its companion, and only within the last few days I have been obliged to remove a young Griffon received from Gibraltar last summer, witlı whom both the Vultures just mentioned have lived amicably hitherto. I believe, though I am not certain of the fact, that these Vultures occasionally carry off large bones to their haunts among the rocks, and, letting them fall from great heights, devour the fragments; and I remember to have read a statement in the 'Field' some years ago to the effect that the writer had watched some Griffons carrying on this performance with tortoises in European Turkey, in a locality with which I am well acquainted. If it were not for the mention of the particular spot, and the number of birds said to have been engaged in this manner, I should have assumed that the writer was mistaken in his identification, and that the tortoise-smashers were really Bearded Vultures (Gypaëlus barbatus). 

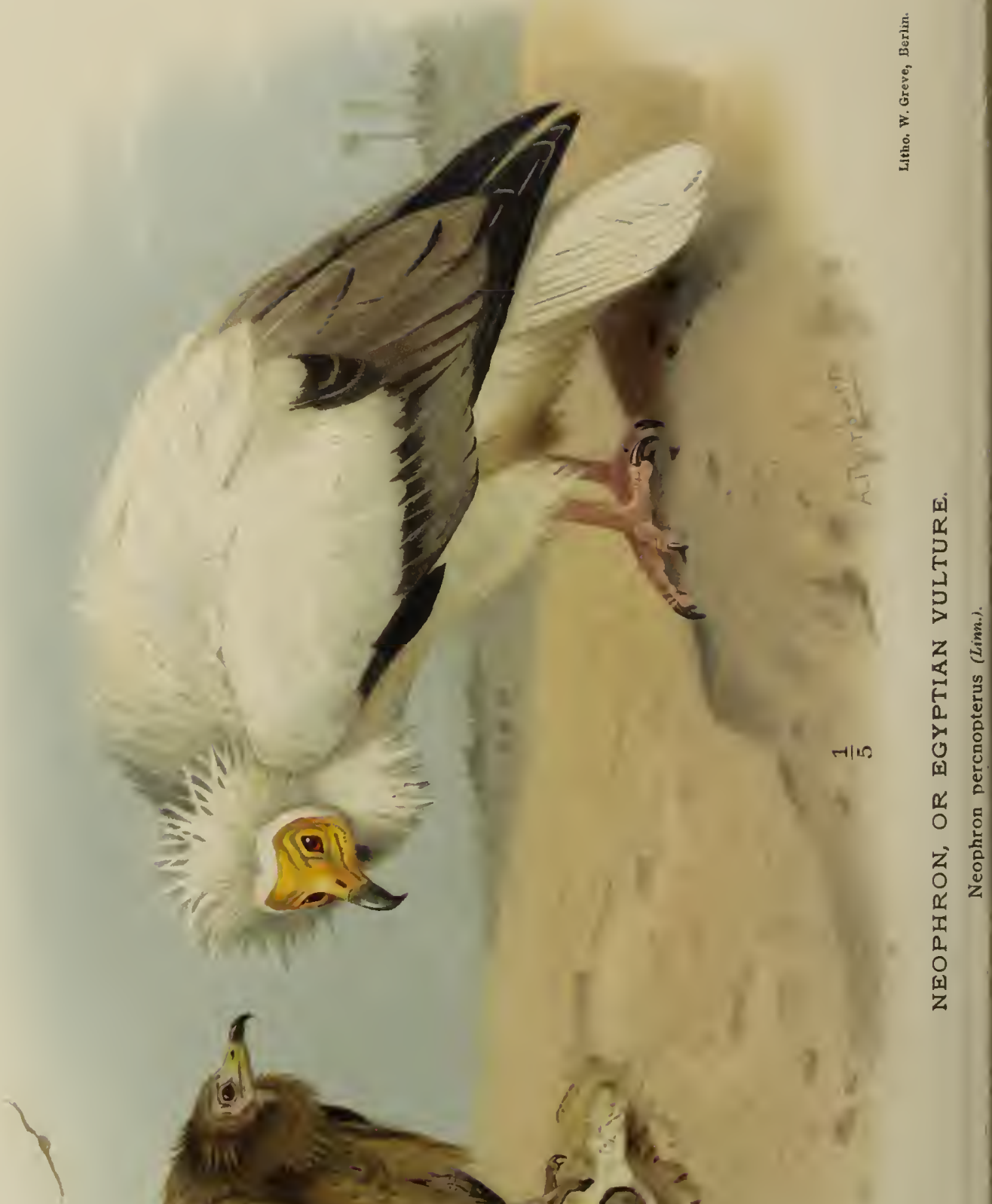


\title{
NEOPIIRON, OR EGYPTIAN VULTURE.
}

\author{
NEOPHRON PERCNOPTERUS (Linn.).
}

Vultur percnopterus, Limn. S. N. i. p. 123 (1766) ; Hewitson, i. p. 5.

Cathartes percnopterus, Naum. i. p. 170.

Neophron pcrcnopterus, Macg. iii. p. 166; Yarr. ed. 4, i. p. 6 ; Dresser, v. p. 391.

Vautor d'Egypte, French; Aas-Vogel, Aas-Geier, German; Alimoche, Rejilero, Abanto, Quebrantahuesos, Grajo blanco, Spanish.

This repulsive but most useful bird has occurred at least on two occasions in England: in the first instance two were seen, and one of them shot, in Somersetshire in October 1825; the second occurrence is recorded by Ductor C. Bree in the 'Zoologist' for 1868 as having taken place on the 28th of September of that year, near Peldon in Essex; all three birds seem to have been in immature plumage. 'The Neophron is a summer visitor to many parts of Southern Europe, and breeds occasionally, to my personal knowledge, as far to the north as the neighbourhood of Aix les Bains in Savoy. In Spain, espccially in Andalucia, this species is exceed. ingly common. Colonel Irby, in his 'Ornithology of 
the Straits of Gibraltar,' states that many pass northwards at the end of February, but the greater number, almost always in pairs, during Mareh. In the immediate neighbourhood of Seville I have only observed one during the month of February, but lower down the Gadalquivir have found these Vultures in considerable number early in March. I have been assured that a few Neophrons pass the winter in the plains of Andalueia, but I eannot affirm this as a faet, and believe that the great majority leave Spain at the approach of autumn. In very many loealities in Southern and Central Spain, where a broken hillside from its steepness attains to the dignity of a cliff, and presents eonvenient ledges or clefts, a pair or two of the Neophron may be found breeding. The nests are eomposed of dead sticks, upon which the birds pile up a mass of every imaginable rubbish that they can piek up about their favourite resorts-heaps of excrement and refuse that abound in and about almost every village. In faet, whilst the larger Vultures are usually more or less shy of approach, and, for the most part, satisfy their appetites upon the remains of large animals in the open plains, the present species is ubiquitous, and seems to be as mueh at home in a village-street as when following the plough for grubs and worms, or watching for lizards and centipedes amongst the lofty limestone roeks of the mountainranges. I have generally found the Neophron in pairs, but a good many may occasionally be found congregated about any large skeleton from which the more powerful earrion-birds have removed the flesh and entrails, attracted, as I believe, not only by the ehance of 
picking up any fragments of the banquet, but also by the beetles that are in that line of business. Nothing eomes amiss to this bird in the way of food, but I think that, altlough they readily devour small snakes, lizards, frogs, scorpions, eentipedes, and beetles, they prefer the most disgusting filth and the most odoriferous deeaying garbage to living animals of any sort. On one oeeasion I observed two of these birds, a White Stork, two or three eur-dogs, a sow and lier pigs, a starving cat, and three young ehildren apparently enjoying themselves on a heap of what I will eall "refuse," in the main street of a Spanish village. I am assured that the Neophron frequently nests in trees, but all the oceupied nests that I have seen have been in the hollows of eliffs, generally at no very great elevation. I must, however, mention that $I$ am aequainted with one instance in which a pair of Neophrons took possession of a nest of the Common Kite, from whieh the original owners had been destroyed and their eggs taken. The eggs are laid in April, but I do not think that the young leave the nests before July. Onl wing, at some distance, the Neophron presents a very remarkable appearanee, giving (to me at least) the impression of a bird flying without a liead; but it is only when on wing that this speeies is not repulsive in the highest degree. Its aspect is in keeping with its labits and charaeter-a coward and a bully of the lowest type, and withal a perfeet instrument, as far as its capacities extend, for sanitary purposes in countries where the human inhabitants ignore the most obvious preeautions against pestilence.

'Tlıe bird from which the principal figure in my Plate 
was taken is one of several that I have received at various times from Spain; he lives in a yard with a collection of other more or less raptorial birds, is perfectly tame, sometimes impudent, cleanly in plumage, but sneaking and cowardly in disposition. 



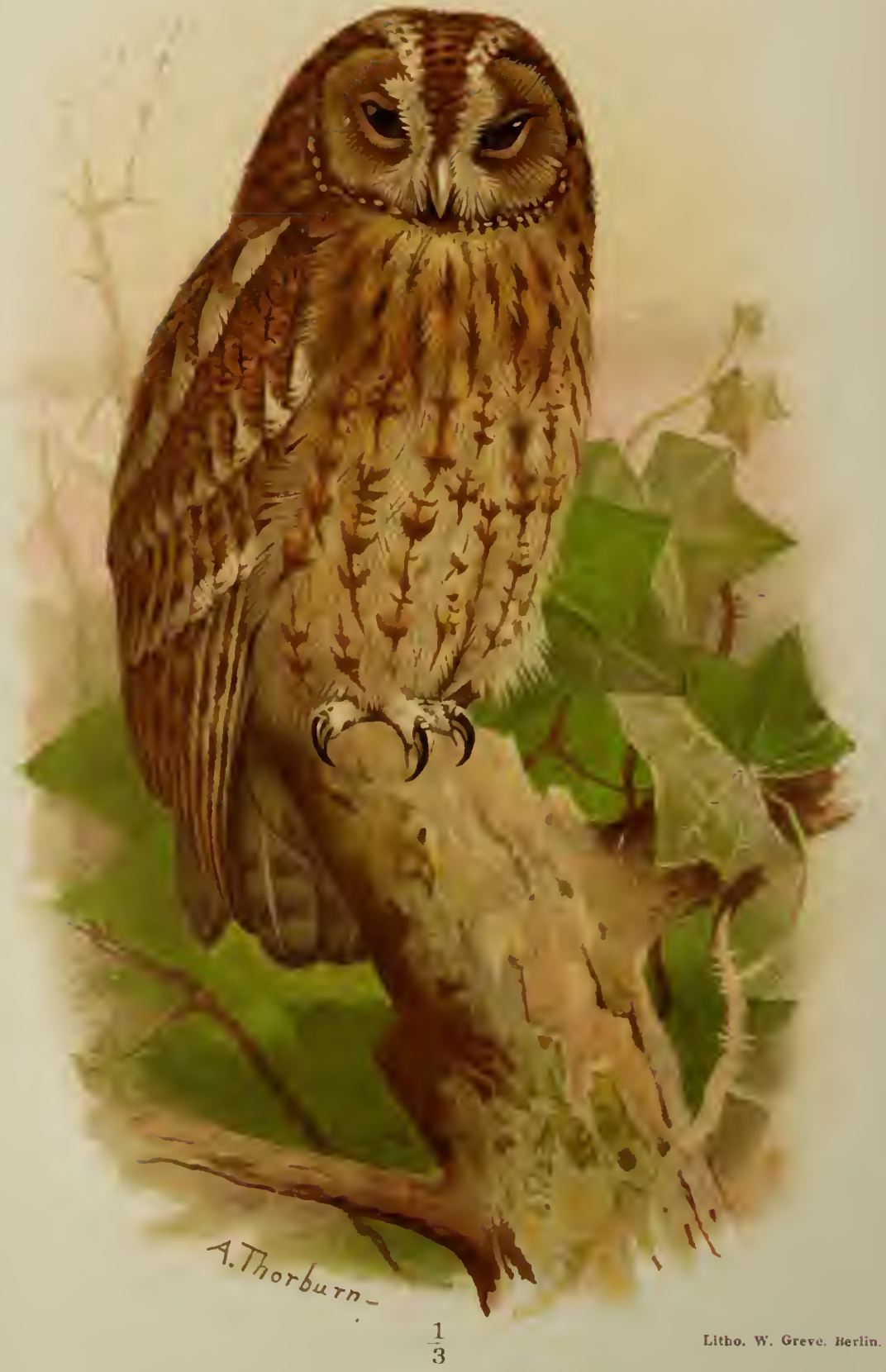

TAW NY, BROWN, OR WOOD-OWL. 


\title{
TAWNY, BROWN, OR WOOD-OWL.
}

\author{
SYRNIUM ALUCO (Linn.).
}

Strix aluco, Linn. S. N. i. p. 132 (1766) ; Naum. i. p. 473;

Yarr. cd. 4, i. p. 146.

Ulula aluco, Macg. iii. p. 438.

Syrnium stridula, Hewitson, i. p. 63.

Syrnium aluco, Dresser, v. p. 271.

Chat-huant, French ; Wald-Kantz, Wald-Eule, German ; Cárabo, Spanisl.

The Brown Owl, as it is generally termed, is still tolerably common in the woodlands of England and Scotland, in spite of the constant and senseless persecution that it has suffered from in many places through the stupid want of discrimination on the part of greedy game-preservers and their servants. I have done my best through my life to protect and eneourage Owls of all kinds, and have been rewarded not only by the conscquent opportunities of close observation of their most interesting habits, but also by their keeping the numbers of mice, voles, and, in a lesser degree, of rats within nearly tolerable limits. 'This Owl especially loves the concealment of old hollow trees, and does not, to ny knowlidge, often frequent old buildings, unless, indecd, they are densely clad with ivy; nor docs it secm 
particularly to affect the derise plantations of conifers that form such favourite retreats for the Barn-Owl. The present bird is an early breeder, the young being often strong on the wing by the beginning of May: the usual site of its nursery is a spacious hollow in the trunk or large limb of an old tree, but I have known several instances of its laying in rabbit-burrows or amongst tree-roots above ground, and one or two of its having taken possession of an old nest of Crow or Wood-Pigeon. Shakespeare has rendered the hoot of the Tawny Owl famous for all time; and though I cannot quite agree with the bard in considering it as a "merry note," it is exceedingly pleasant to my ears, and brings back memories of the happy days when Owls were to me birds of mystery, now dispelled by years and diligent study of their habits, which have led me to a full appreciation of the beauty and infinite merits of these unpaid friends of man. 


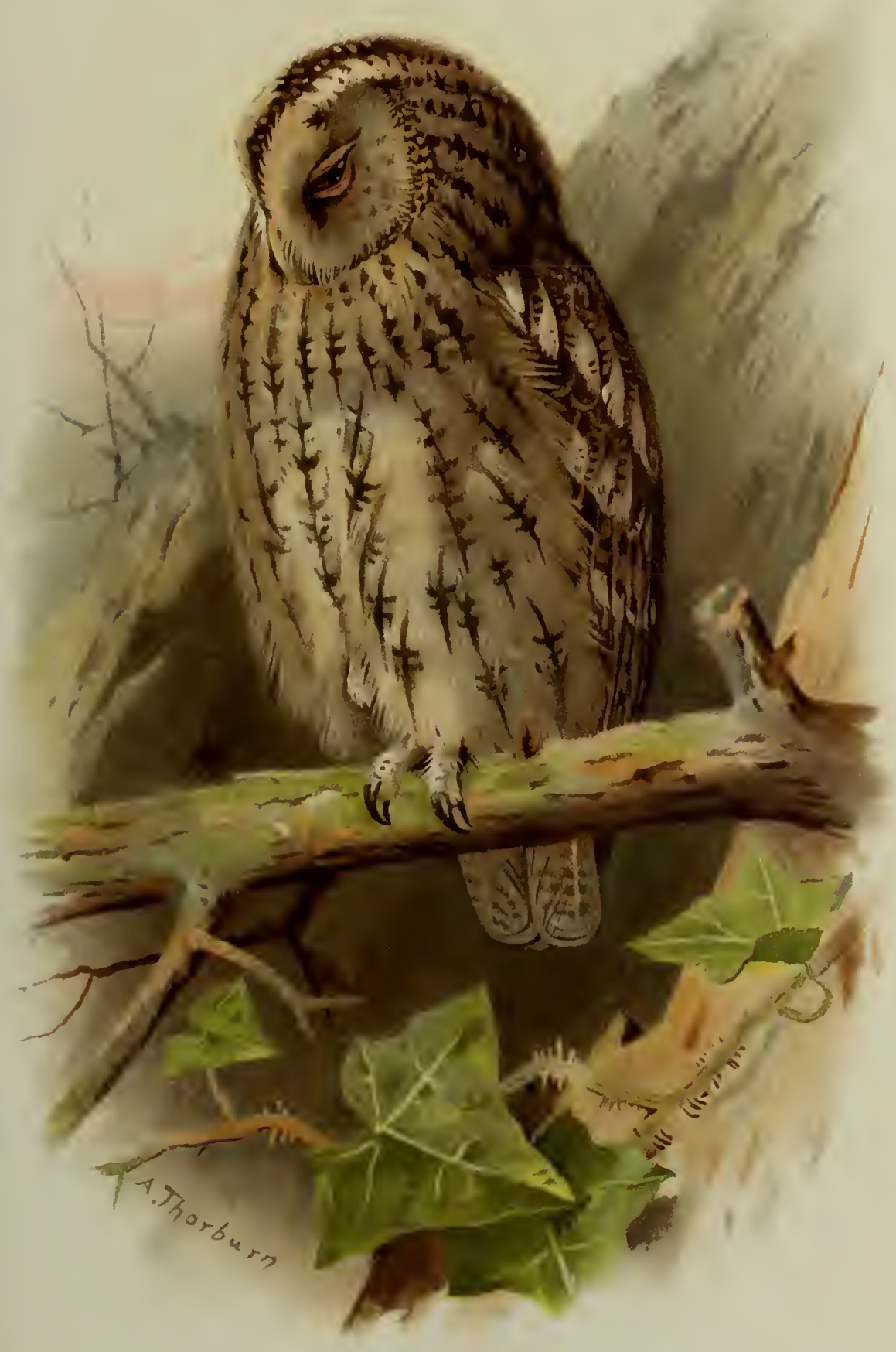

TA WNY, TROIN, OR WOOD.OWL. Grey Raie.

Syrnium aluco(Linn.). 




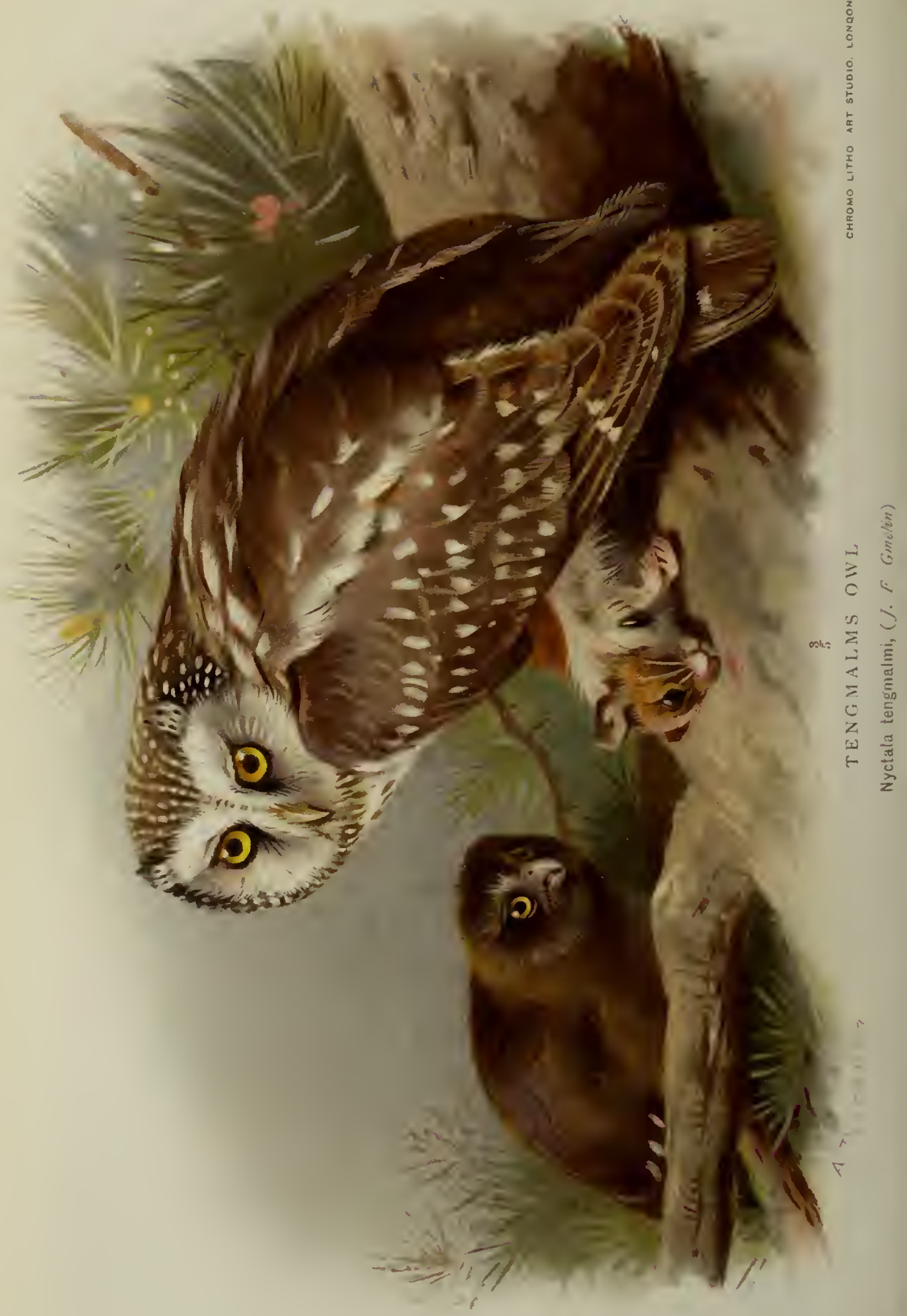




\section{TENGMALM'S OWL.}

NYCTALA TENGMALMI (J. F. Gmelin).

Strix tengmalmi, J. F. Gmelin, S. N. i. p. 291 (1788);

Naum. i. p. 500.

Ulula tengmalmi, Macg. iii. p. 445.

Noctua tengmalmi, Hewitson, i. p. 66.

Nyctala tengmalmi, Yarr. ed. 4, i. p. 154; Dresser, v. p. 319.

Chouette Tengmalm, French; Tengmalm's Kautz, German.

'This Owl is an accidental and uncommon straggler to Great Britain from the forest countries of Northcastern Europe, where it is locally abundant. Of its habits in natural conditions of existence I can say nothing from personal experience, and I have been unfortunate with the few of this species that I have attcmpted to keep alive in captivity. I quote from the 4.th ed. of 'Yarrell' to the cffect that this Owl inhabits thick forests in Norway, Sweden, and Russia, even in very high northern latitudes. It is well known locally throughout the larger forests of Central Europe, occurs occasionally in Northern Grecce, has been obtaincd in the Crimca, and inliabits the Alpine forests of Italy, Switzerland, and Savoy.

Irollcy announced to the Zoological Socicty in 1857 
that this bird lays its eggs in holes of trees, or in the nest-boxes set up by the inhahitants of Lapland for the accommodation of Goldeneye Ducks and other holebreeding water-fowl. The number of eggs varies from four to seven. I received five of this species alive from Helsingfors in the summer of 1888. I did not notice that their habits differed from those of other WoodOwls in captivity, except that they were much less active and savage than some Hawk-Owls received in the same consignment. They were voracious feeders and great bathers, and seemed to be in no way inconvenienced by bright sunlight. The chief peculiarity of these birds was their cry, which, as mentioned by Wheelwright, is a very musical, long-drawn whistle, quite unlike the note of any of the numerous Owls with whom I have the honour of personal acquaintance. Although these little Owls seemed to bear captivity well, and did not exhaust themselves by struggling to escape, I lost them all within two years, and vainly tried to discover any cause for their death. 



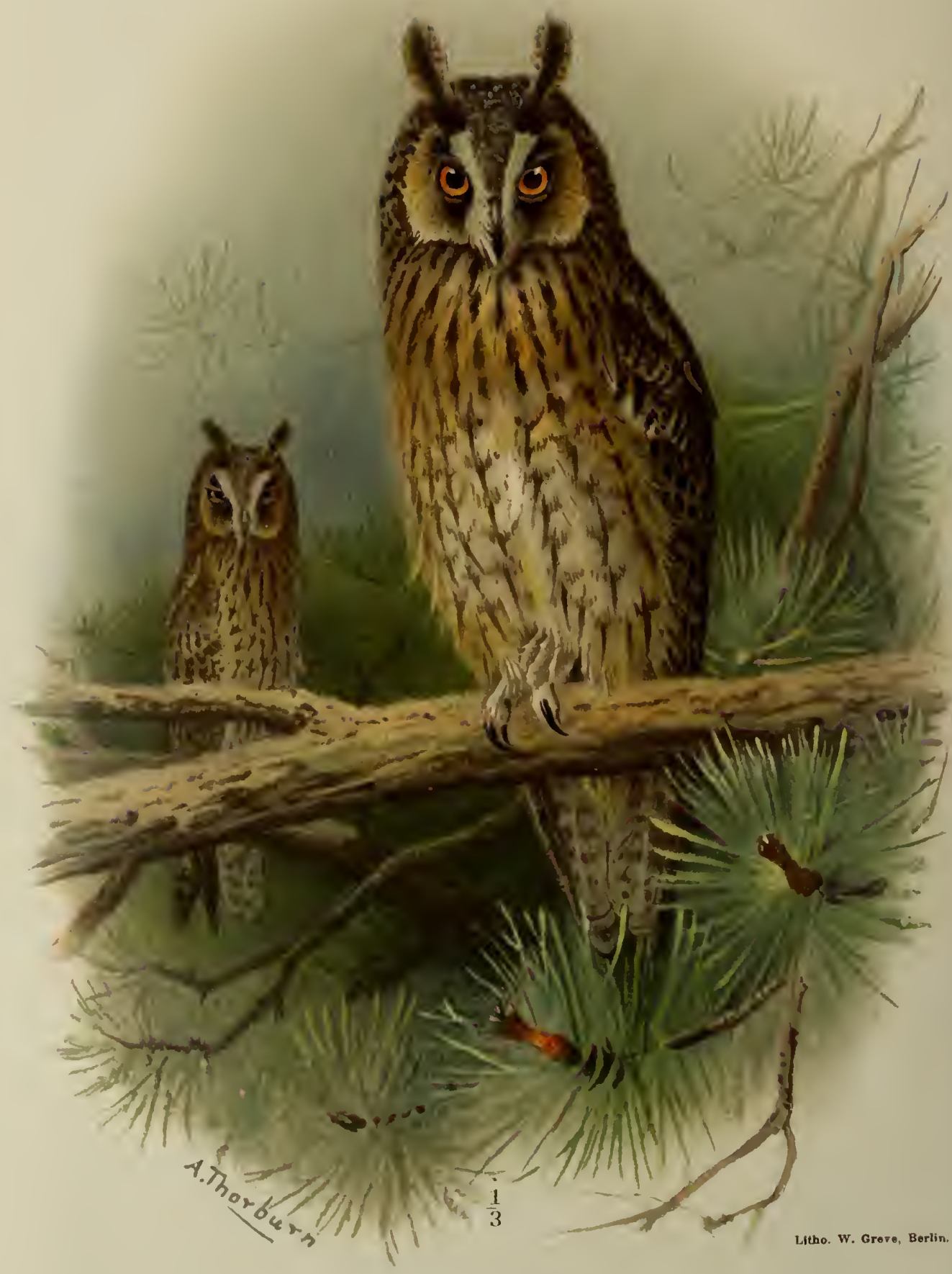

LONG-EARED OWL.

Asio otus (Linn.). 


\title{
LONG-EARED OWL。
}

\author{
ASIO OTUS (Linn.).
}

Strix otus, Linn. S. N. i. p. 132 (1766); Naum. i. p. 451.

Asio otus, Macg. iii. p. 453 ; Yarr. ed. 4, i. p. 158 ; Dresser, v. p. 251.

Otus vulgaris, Hewitson, i. p. 55.

Hibou vulgaire, Freneh; Ohr-Eule, German; Carabo, Buho, Spanish.

This handsome Owl is tolerably abundant, though extremely local, throughout the United Kingdom, but prefers, so far as my own experience goes, thick plantations of coniferous trees to any other localities. In West Norfolk and Suffolk the Long-eared Owl would be, if unmolcsted, exceedingly common; I have frequently scen from ten to a dozen of these birds in the course of a day's shooting in those districts, but I grieve to add that on one occasion prominently in my memory, several members of our party, not imbued with that love for Owls that inspires me, were guilty of the blood of these very beautiful birds. The egros of this species, gencrally four or five in number, are usually laid carly in March in an old nest of Crow, Magpie, Wood-Pigcon, 
or Jay; the only Northamptonshire nest of Long-eared Owl that I have examined appeared to me to consist of the cup of the old nest of a Magpie with a broad fringe or bordcr of fir-twigs, apparently added by the Owls themselves. In the north of Ireland and in Norfolk the many nests occupied by this species that I have found appeared to me to be those of Wood-Pigeons, but I think that in almost every instance the Owls had added to the original structure. I have several times come upon a family of this species sitting close to each other in a row on the same bough of an old Scotch fir, and apparently as regardless of my presence at the foot of the tree as I was delighted at the opportunity of making their acquaintance under natural conditions. The attitudes and expressions of a group of these birds when not alarmed are incxpressibly comical.

A considerable number of Long-eared Owls cross the North Sea to our eastern coasts annually in November and December; I was assured by my friend the late Mr. G. E. Hunt that on one occasion in a large wood not far from the coast of Suffolk, when he was sent forward to deal with rocketting pheasants, some sixty or seventy at least of these Owls crossed the little valley in which he stood. This Owl does not, so far as I am aware, frequent buildings or hollow trees, but is fond of dense masses of ivy, and was often found in the almost impcnetrable thickets of blackthorn which are, or perhaps I should say were, so characteristic of the forest-district of Northamptonshire. The cry of the Long-eared Owl at pairing-time is a prolonged and most disagreeable scream, at other seasous the only note that I have heard 
uttered by this species may best be described as a short yelp. In the island of Corfu we found this Owl tolcrably common, and generally frequenting the thickest covert of arbutus, myrtle, and other evergreen shrubs; I once disturbed one from a thick orange-trce. In captivity these birds become extremely tame and are most interesting pets, but do not thrive so well as several other species of the family, although I have succeeded occasionally in keeping one of them alive for threc or four years. The Long-eared $\mathrm{O} w \mathrm{l}$ is generally distributed in suitable localities throughout Europe. 




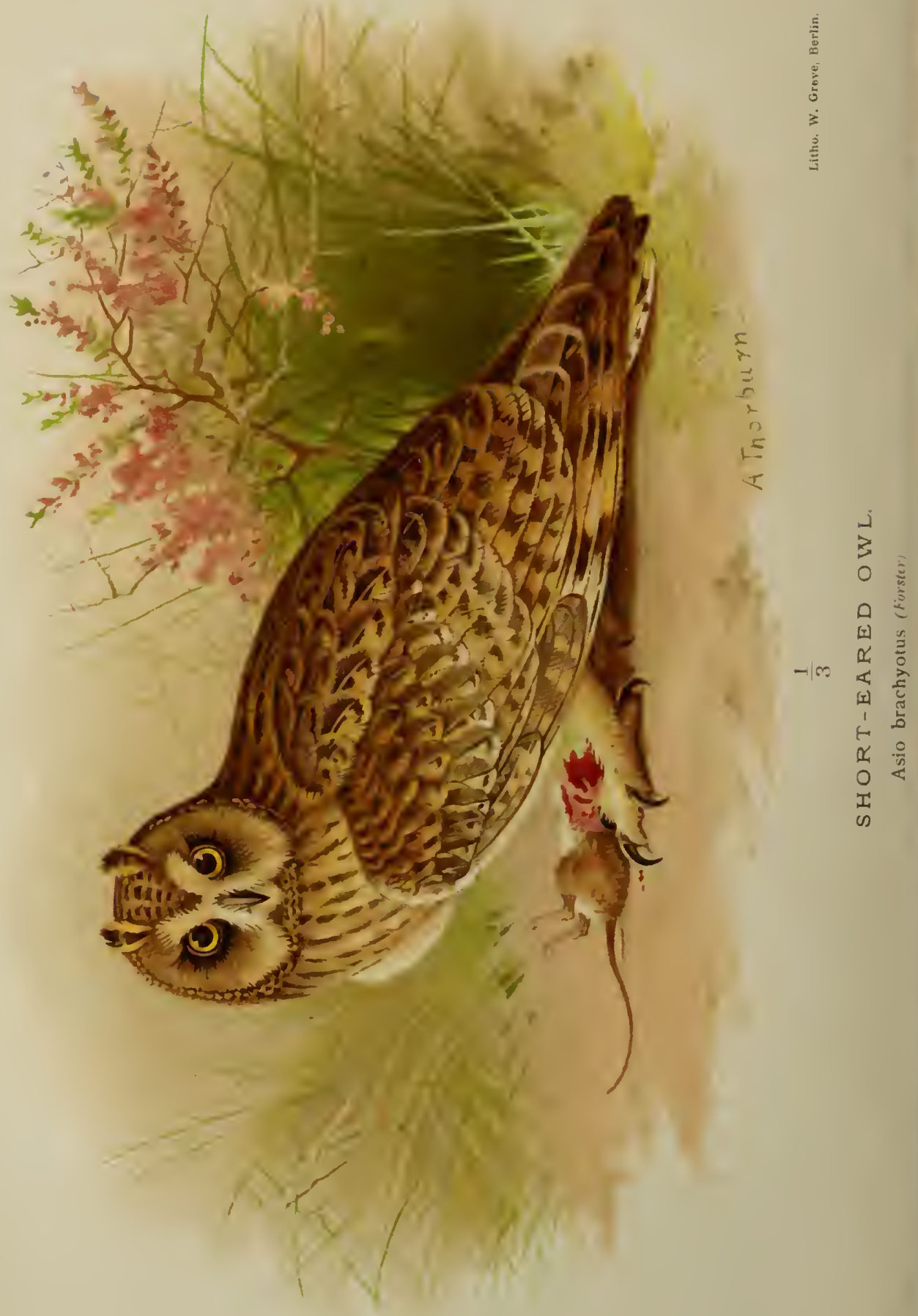




\title{
SHORT-EARED OWL.
}

\author{
ASIO BRACHYOTUS (Forster).
}

Strix brachyotos, Forster, Phil. Trans. Ixii. p. 384 (1772).

Strix brachyotis, Naum. i. p. 459.

Asio brachyotus, Macg. iii. p. 461.

Otos brachyotos, Hewitson, i. p. 58.

Asio accipitrinus, Yarr. cd. 4, i. p. 163 ; Dresser, v. p. 257.

Hibou brachyote, Fronch; Sumıf-Ohreule, kurzöhrige Eule, German; Cárabo, Lechuza campestre, Spanish.

The Short-cared Owl is most generally known in England as an autumnal migrant; but a few pairs still breed in certain fens and moorlands in our country, which, in the interest of the bird, I refrain from specifying; in certain parts of Scotland and its adjacent islands it nests pretty commonly, and is very frequently met with in Ireland in winter. The habits of this Owl differ from those of almost all the other spccies of its family in the fact that the prescut bird is eminently terrestrial, seldom alighting on trces, and preferring open country with covert of hcath, fern, or scdge. We often mect with this $\mathrm{O}$ wl in turnip-fields or rough pasturclands in the midlands towards the end of October, sometimes in considerable numbers, but, as a rule, singly or in couples; in West Norfolk, at the sanic scason, I 
have more than once seen a dozen or more during a day's shooting.

'The Short-eared Owl is a very powerful flyer, and, as he often hunts not only by daylight, but in bright sunny weather, it is evident that his vision is better adapted for diurnal operations than is the case with our other British Owls. T'he nest of this bird when situated on dry heath-lands is merely a scraping of the carth, but in the fens the eggs are often laid upon a few pieces of broken reed-stems, with occasionally a few leaves of that plant, or blades of broad sedge; the eggs are pure white, and vary in number from four to six. This is one of the most useful of birds, as its favourite prey are the noxions voles that infest our low-lying lands. 


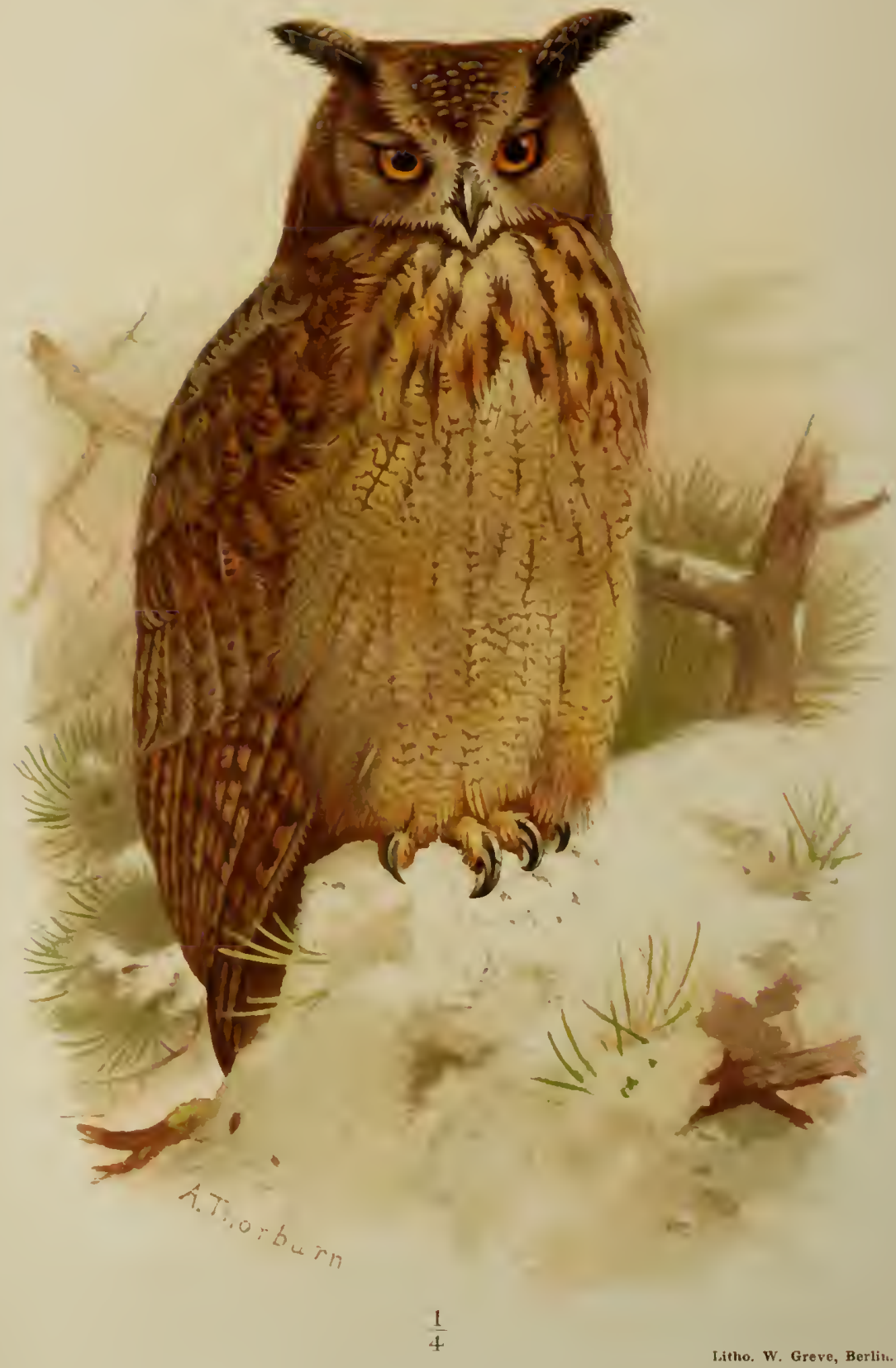

EAGLE-OWL.

Bubo maximus, Fleming. 


\section{EAGLE-0WL.}

BUBO MAXIMUS, Fleminy.

Bubo maximus, Fleming, Brit. An. p. 57 (1828); Macg. iii. p. 428 ; Hewitson, i. p. 50.

Strix bubo, Naum. i. p. 440.

Bubo ignavus, Yarr. ed. 4, i. p. 163; Dresser, v. p. 339.

Hibou Grand duc, French; Uhu, Bergeule, Grossherzog, German; Buho grande, Buho real, Spanish.

Several instances are on record of the occurrence of this grand bird in Great Britain, but it is very probable that some of these may refer to "escapes" from captivity, though, indeed, many of the wilder parts of our country are eminently well suited to the habits of the Eagle-Owl, which is more or less common in mountainous and forest districts throughout the continent of Europe. In Epirus we frequently met with it during our shooting-excursions, and still more often heard its sonorous call, which is well represented by its common German name above given. In the sierras of Spain, too, the present species may be called abundant, and may often be heard on the Rock of Gibraltar, whence I once obtained a living specimen.

The Eagle-Owl, in common with most of its family, renains in concealment in the fissures and caves of 
cliffs, or in dense foliage, during the daytime, and sallies forth at dusk in quest of its prey, which consists of birds, and, where they cxist, hares and rabbits. In Epirus I an convinced that, during the autumn and winter months, thesc Owls fed principally upon wildfowl, which they seized as they were feeding on the open marshy lands by night. This bird is a very early brezder, usually commencing to lay early in February; the eggs are pure white, much rounded in shape, and generally from two to four in number; very little ncst is made, the eggs being generally laid on a bare earthy ledge of cliff ( $\mathrm{I}$ am, of course, only writing of my own expericnce).

The Eagle-Owl will live in confinement for a great number of years, if not over-fed and allowed to take a sun-bath when so inclined. We have reared several young of this species at Lilford from eggs laid in the aviarics, but from somc hitherto unexplained cause have not of late years met with the success in this direction that has attended other English possessors of these Owls in captivity. 


\section{SCOPS 0WL. \\ SCOPS GIU (Scop.).}

Strix Scops, Linn. S. N. i. p. 132 (1766).

Strix scops, Naum. i. p. 466.

Scops aldrovandi, Macg. iii. p. 422 ; Hewitson, i. p. 54.

Scops giu, Yarr. ed. 4, i. p. 173 ; Dresser, v. p. 329.

Le Petit Duc, French; Zwerg-Ohreule, German; Corneja, Spanish.

A rare visitor to our islands; abundant as a summer migrant in many parts of Southern Europe. 


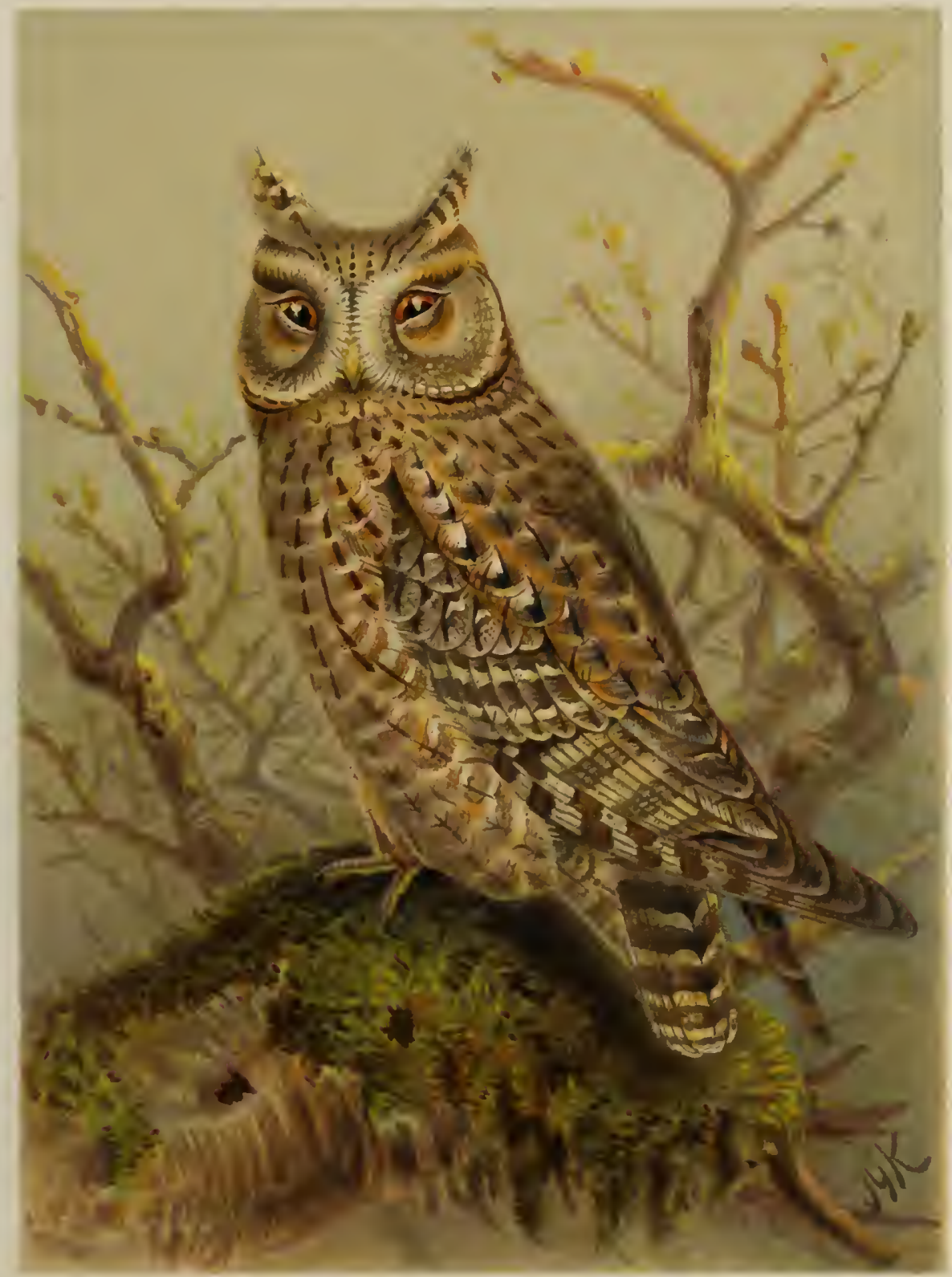

Litho. W. Grere, Rerlin-London.

S COPS O WL.

Scops giu. IScop.) 



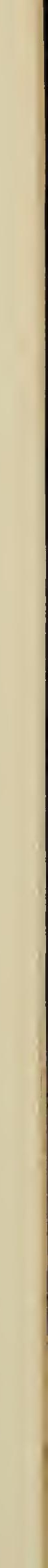




\section{LITTLE OWL.}

ATHENE NOCTUA (Scop.).

Strix noctua, Scopoli, Ann. I. Hist.-Nat. p. 22 (1769); Naum.

i. p. 493.

Syrnia psilodactyla, Macg. iii. p. 417.

Noctua nudipes, Hewitson, i. p. 67.

Carine noctua, Yarr. ed. 4, i. p. 178.

Athene noctua, Dresser, v. p. 357 .

Chouette chevêche, French; Stein-Kautz, German; Mochuelo, Cu-cu, Spanish.

Common in most parts of Southern and Central Europe; rarely visits our islands. 


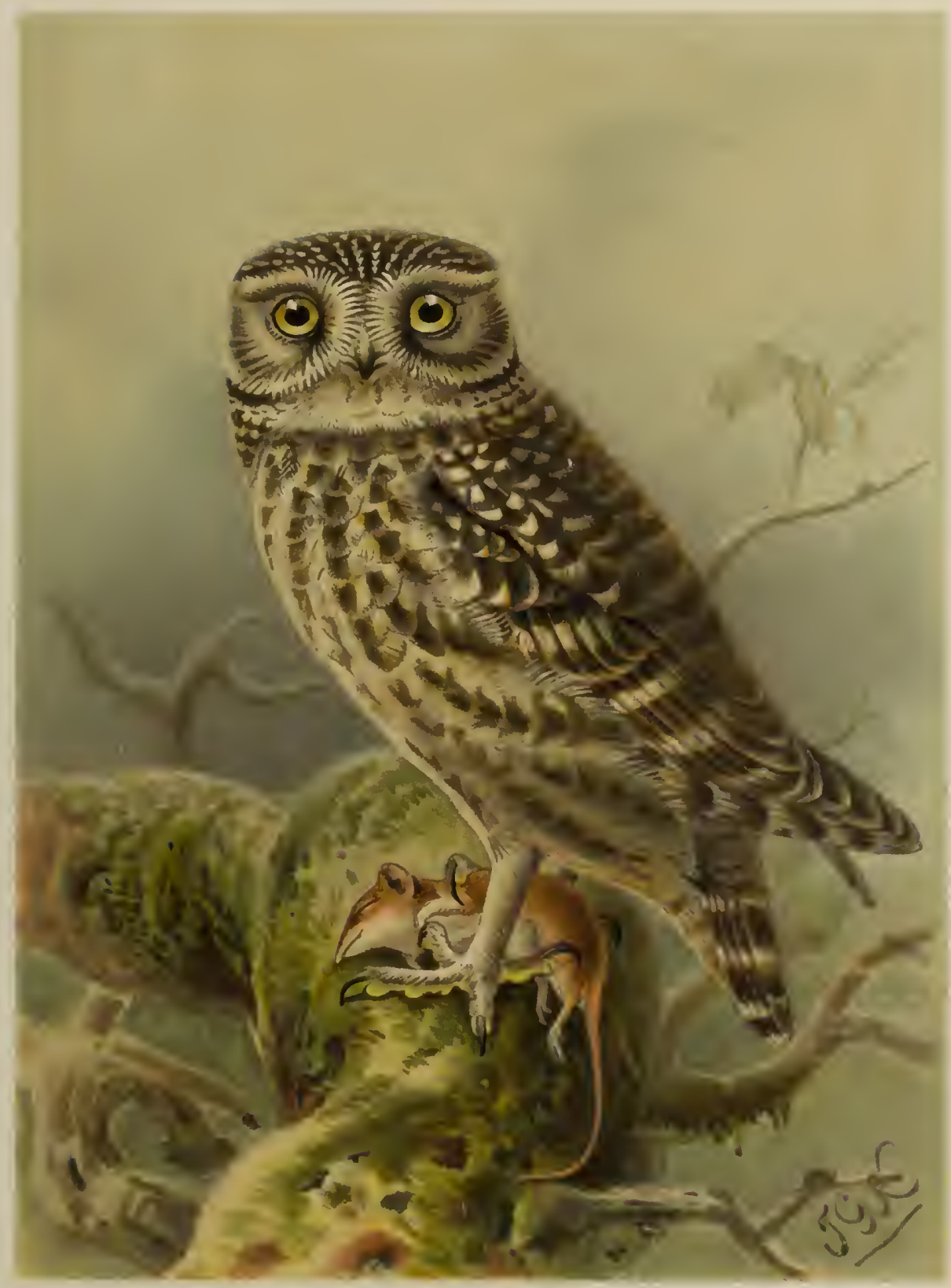

Litho. W. Greve, Berlln-London.

L I T T LE O W L.

Athene noctua (Scop.) 




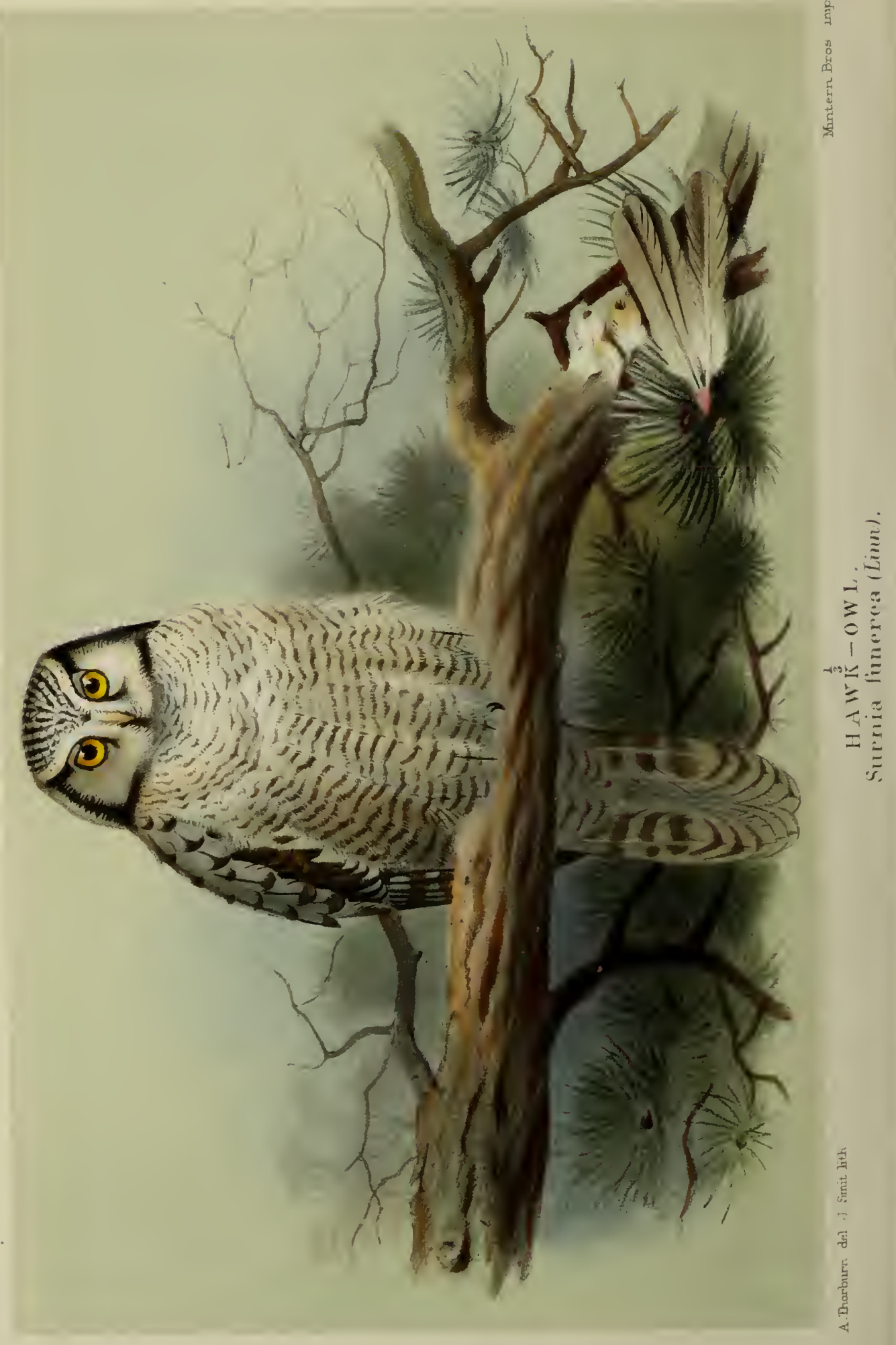




\section{HAWK-OWL.}

SURNIA FUNEREA (Linn.).

Strix funerea, Linn. S. N. i. p. 133 (1766).

Strix nisoria, Naum. i. p. 427.

Syrnia funerca, Macg. iii. p. 404.

Surnia funerea, Hewitson, i. p. 65 ; Yarr. ed. 4, i. p. 183 ; Dresser, v. p. 309.

Chouette caparacoch, French; Habichtseule, German.

The specimens of this bird that have occurred in the British Islands have been few and far between. I quote from Mr. Howard Saunders' recently published 'Manual' as to dates and localities :-One off the coast of Cornwall, March 1830. One near Yatton, in Somersetshire, August 1837. One on the island of Unst, Shetlands, in the winter of 1860-61. One near Glasgow, December 1863. One near Greenock, November 1868. One near Amesbury, Wilts, for which no precise date is given. I find that Mr. J. E. Harting, in his 'Handbook of British Birds,' published in 1572, records two other occurrences-one at Shelf, near Bradford, without date, and another near Greenock, in December 1871.

This Owl is an inhabitant of the pine-forests of Northern Europe, Asia, and America, and as I know 
nothing whatever of its natural habits in freedom from personal observation, I refrain from further quotations. I received eight of these Owls alive from Helsingfors in July 1888, one of which is representcd in accompanying Plate. These birds are very fearless and savage, very quarrclsome amongst themselves, always wide-awake and ready for food, and constantly uttering a very melancholy and unpleasant cry. The $\mathrm{N}$. American race of Hawk-Owl, which has been described as a distinct species by some ornithologists, differs principally fiom the European form in the broader and redder colour of the transverse bars on the underparts, but, in my humble opinion, is in no way worthy of specific separation therefrom; it appears that the majority of the Hawk-Owls that have bcen captured in Great Britain belong to this American race. 



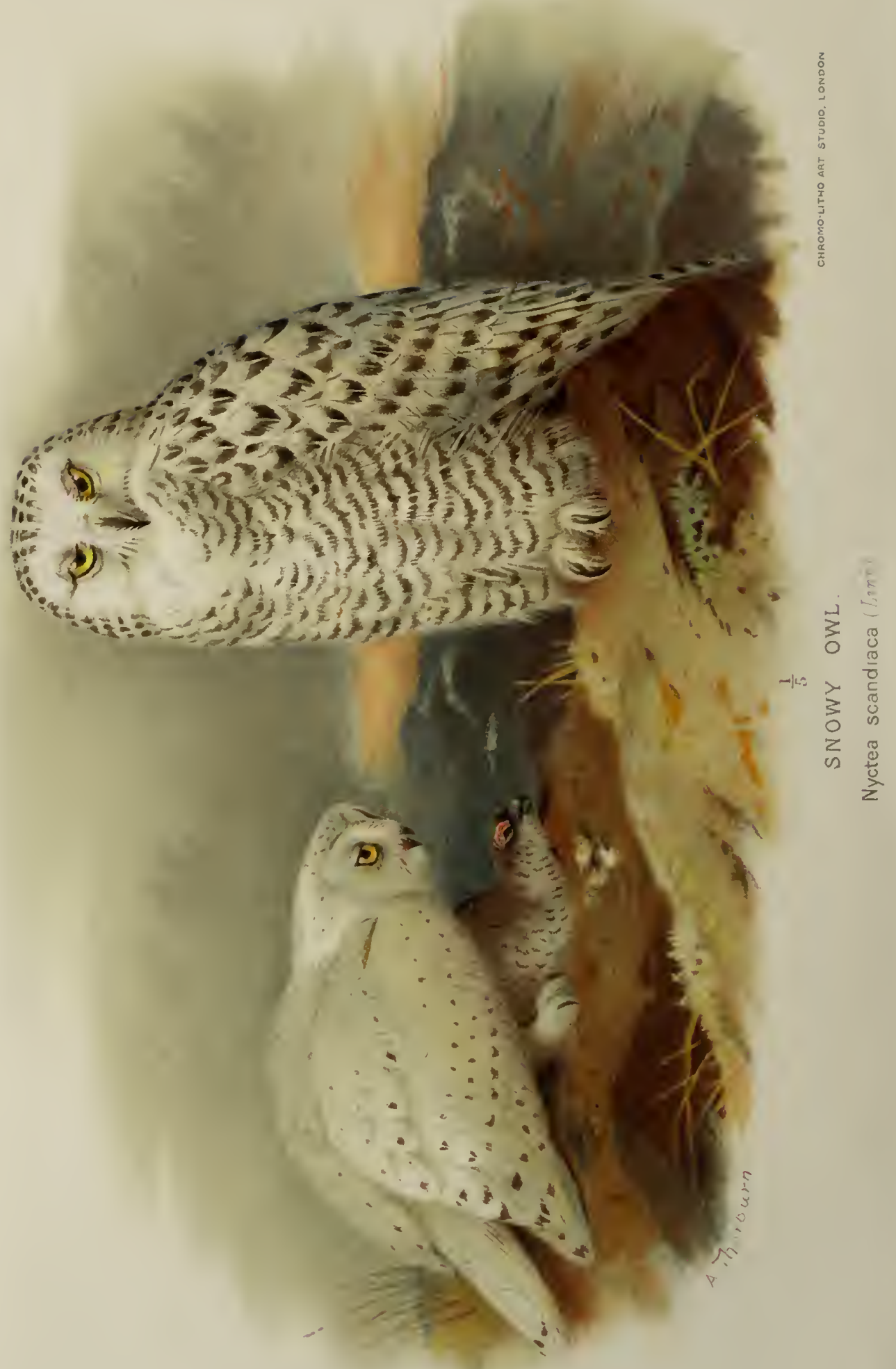




\section{SNOWY 0WL。}

NYCTEA SCANDIACA (Lim.).

Strix scandiaca, Linn. S. N. i. p. 132 (1766).

Strix nyctea, Naum. i. p. 417.

Syrnia nyctea, Macg. iii. p. 407.

Surnia nyctea, Hewitson, i. p. 64.

Nyctea scandiaca, Yarr. ed. 4, i. p. 187; Dresser, v. p. 287.

Surnie Harfang, French; Schnee-Eule, German.

This fine Owl, whose true home is in the extreme north of the Old and New Worlds, is an occasional straggler to the British Islands, and fide Mr. Robert Gray, as quoted in the 4th edition of 'Yarrell,' may be regarded as an almost regular spring visitant in the Outer Hebrides. I have never had the good fortune to meet with the Snowy Owl in a wild state, so that I can add nothing to the details already published concerning its habits and haunts in that condition, but I may mention that it is a bird of the open country, that it can see to hunt in the brightest sunlight as well as in the gloom of night, that it follows the migrations of the lemmings, and consequently is occasionally abundant in districts where perhaps it may previously have been barely known. Its food consists of hares and smaller 
Mammalia, birds, and fishes. I have kept many of this species in confinement, but lave been singularly unfortunate with them, as for some unknown reason I have lost them all within three or four years of their arrival at Lilford.

After the death of Mr. Edward Fountaine, of Easton, near Norwich, whose success in rearing Owls in captivity is well known to all British ornitlıologists, I purchased six of this species from his cxecutor, and sent the keeper of my aviaries to fetch them from Easton; they arrived safely at Lilford on August 29, 1889, but the person in whose charge they had been left in Norfolk could give my man no precise information as to their age or sex, nor, indecd, could she positively state which, if any, of the six birds had been bred at Easton; two at least were adult males. On June 4, 1890, a pair of these Owls slowed an inclination to nest by scratcling a loole in the gravel of their aviary: we immediately renoved the other birds and left this pair in solc possession of a roomy compartment, protecting them from outside observation by fastening garden matting all round the wired front and one side of the enclosure, which was further protected at the back and other side by a high stone wall. On June 7 the female bird was sitting, and we left her nndisturbed till July 10 ; during this time she was regularly fed by the male, and, as far as we could asccrtain, seldom, if ever, left her nest; the malc bird savagely attacked any one who even opened the door to throw in food, and both birds cried savagely at the mere sound of human footsteps outside thcir abode. On the day last naned my 
man succeeded, in spite of the furious onslaught of the male, in getting his hand into the nest, and extracted an egg containing a lively chick with its beak well through the shell. On July 12 we found that two young birds had been hatched out, and that four of the five remaining eggs were "chipping." On July 20 the nest contained three eggs only, two of which contained dead young birds, whilst the third was rotten; we took this one away, and the next day the nest was empty and deserted, the old birds having certainly devoured the whole of their progeny, as Artemus Ward says " on foot and in the shell." For many days after the final catastrophe the female took to perching, a habit to which she was by no means frequently addicted before she had laid, she now constantly uttered a mournful cry that we had not before heard, very different from her sharp angry bark of menace whilst she was sitting. I am strongly of opinion that in this atrocity the male bird was the chief, if not the sole culprit; but I regret to say that it is now impossible to learn from any future experience how to allot the blame with regard to him, as both he and the only other bird of the six positively known to be a male have died since the events above recorded. 



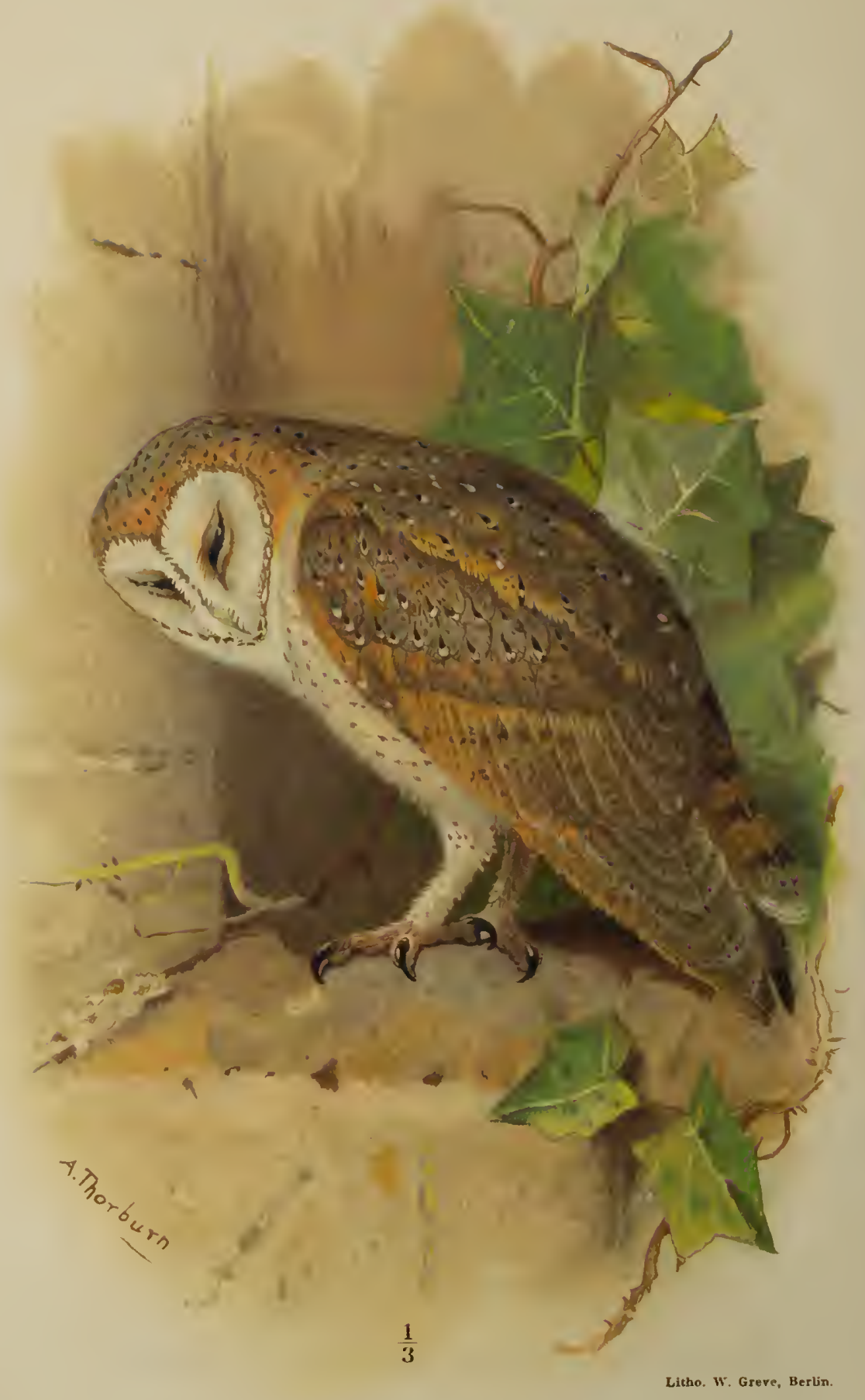

BARN-OWL.

Strix flammea, Linn. 


\section{BARN-OWL。}

STRIX FLAMMEA, Linn.

Strix flammea, Linn. S. N. i. p. 133 (1766); Naum. i. p. 483 ; Macg. iii. p. 473 ; Hewitson, i. p. 61 ; Dresser, v. p. 237.

Alueo flammeus, Yarr. ed. 4, i. p. 194.

Effraye commune, French; Schleier-Eule, German; Lechuza, Spanish.

This most useful of birds is more or less common throughout the United Kingdom, and is perhaps better known as White or Screech-Owl, than by the designation above given. I am glad to believe that the minds of game-preservers and game-keepers are gradually awakening to the fact that in destroying Owls in general, and this species in particular, they are committing acts of the most egregious folly, not only as regards the birds which are the special objects of their care and protection, but also from an agricultural point of view, for these Owls not only destroy enormous numbers of rats, nice, and voles, but also take many Sparrows and other seed-eating birds from their nocturnal resorts; the stolid and unculightened game-kecper may plead that 
Owls do eat birds, and, as I liave just stated, so they do, but if he allows his young hand-reared game-birds to be out of their coops at the time that Owls are abroad in search of food, surely the blame for losing them attaches justly to him and not to the tempted Owl; I need hardly say that wild-bred game-birds, whilst small enough to be attacked by the Barn-Owl, are carefully stowed away under their mother's wings at the time when the "bird of night" is on the quest of prey. I have examined hundreds of the pellets cast up by this species in and under their nesting-places, and never discovered either bones or feathers of any game-bird, the castings consisting mainly of the fur and bones of small mammalia, with feathers and skulls of seed-eating birds, and occasionally a few bones and scales of small fishes. For many years past I liave done my utmost to encourage and protect Owls on my own property, and to urge upon my neighbours to do the same, and I am glad to say that at this time of writing (April 1890) I have authentic information of no less than eleven Owls' nests with their full complement of eggs within a radius of three miles from our home.

The Barn-Owl generally begins to lay early in April, and, I think, begins to sit as soon as one or two eggs are laid, though the full complement of eggs is seldom less than six or seven: I am told that there are nine in one of the nests to which I have just alluded. Young Barn-Owls in all stages from newly-hatched down-clad infancy to full feathcring may be found in one and the same nest at the same time, and there is good reason to belicve that the juniors arc hatehed out by the warmith 
of their elder brethren. I have once or twice seen a Barn-Owl flying apparently on his own account in sunshine, but when suddenly disturbed from their natural shady resorts in the daytime, they generally seem to be quite confused, and fly with a wavering and uncertain flight into the nearest leafy tree. As a rule the BarnOwl sits during the hours of sunshine in a hollow tree, a dark recess in old masonry, a dense mass of ivy, or the gloom of conifers, and emerges from his home at dusk to scour over the fields and about farmsteads in search of food, but in dull winter weather these Owls may often be seen hunting before sunset; their flight is perfectly noiseless, and their quickness of vision in a dim light quite marvellous; they quarter their ground much in the same fashion as the Harriers, and go over the same beat pretty regularly night after night. A young Owl of this species that I kept as a pet in my schooldays, on one occasion, when about half-grown, swallowed nine full-grown house-mice in rapid succession till the tail of the ninth stuck out of his mouth, and he could do no more, but within three hours he was hungry again, and was barely satisfied with four more of the little quadrupeds; with this appetite and capacity for stowage the numbers of four-footed vermin supplied by a pair of Barn-Owls to a brood of six or seven ravening youngsters may well be imagined: I have seen an old pair bring food to their brood seventeen times in half an hour from a rick-yard near their nest. A great number of these and other Owls are massacred and sold to be made into fire-screens and plumes for ladies' hats, barbarities upon which I can hardly trust myself to enlarge; the bird- 
manglers who devote themselves to this branch of art, almost invariably put glass eyes of the wrong colour into the distorted faces of their victims, and in every way shock all the better feelings of our human nature. When unmolested these Barn-Owls will permit very close observation of their ways and manners. 



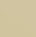





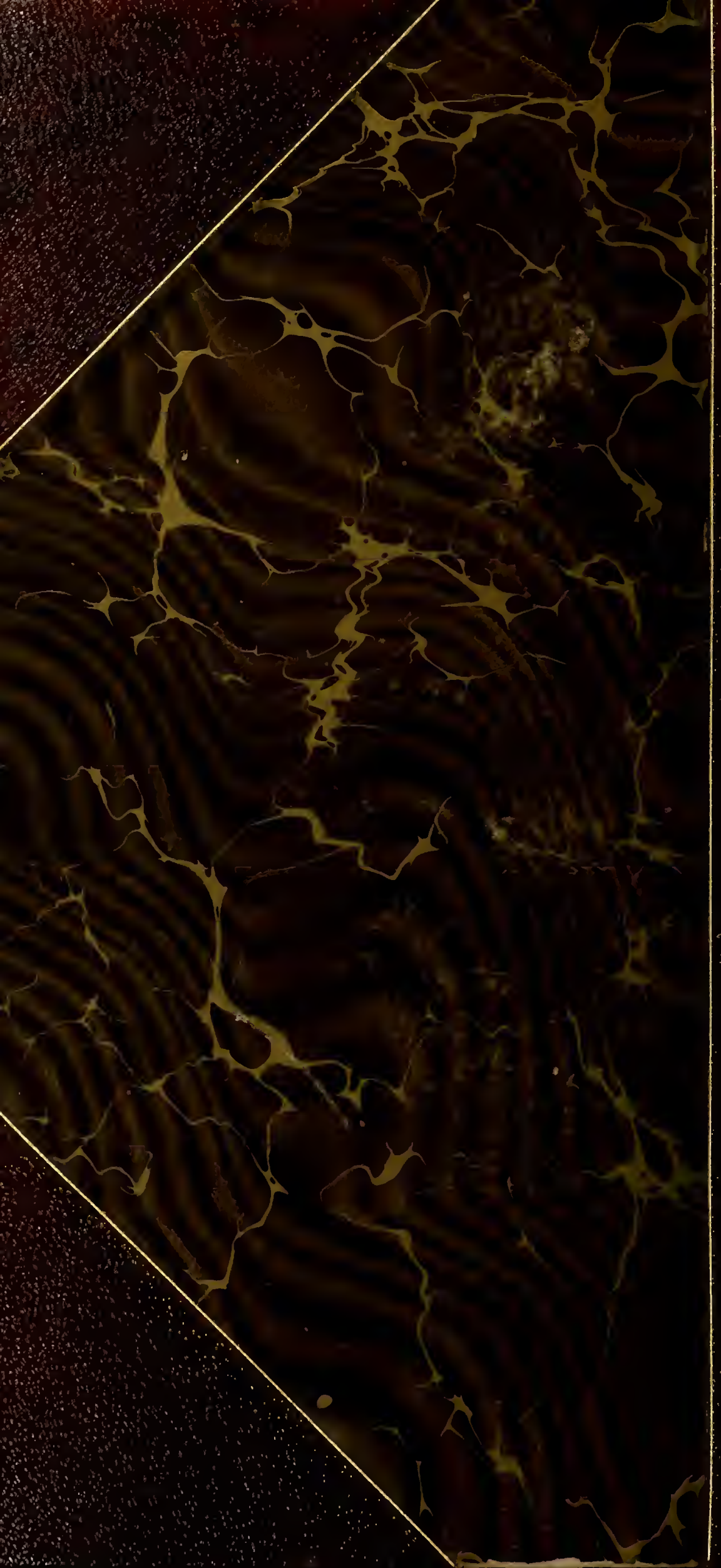

